MWSS. EA 10.2: ST29/997

Guidelines for

Operations

And

Land

Stewardship
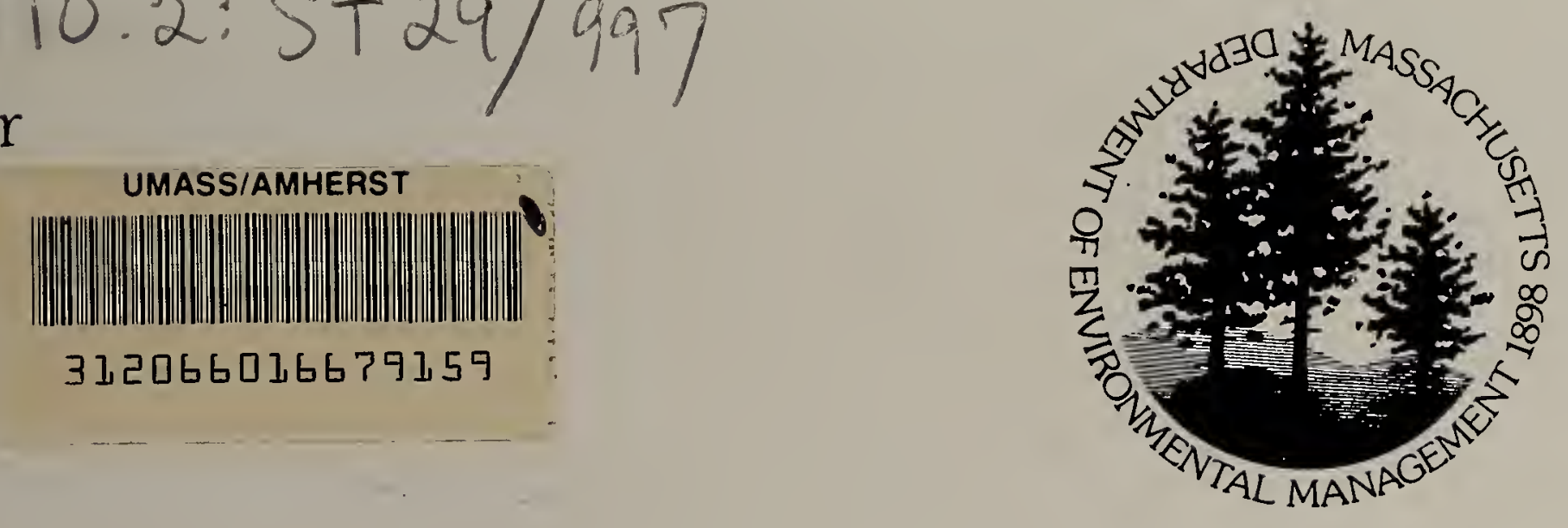

\title{
STATE FORESTS \& PARKS IN THE NORTHEASTERN CONNECTICUT VALLEY REGION
}

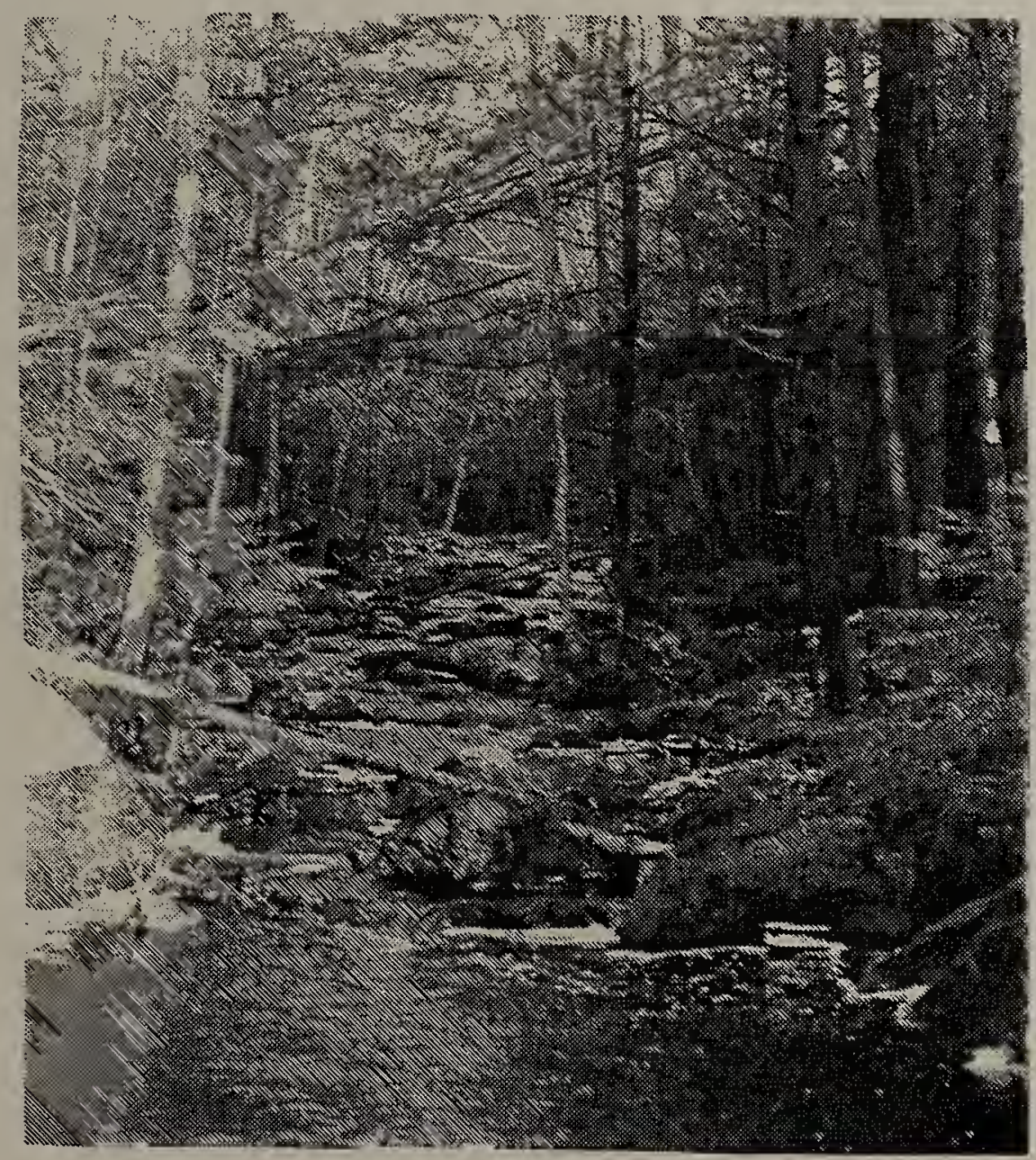

Massachusetts Department of Environmental Management 



\section{STATE FORESTS \& PARKS IN THE NORTHEASTERN CONNECTICUT VALLEY REGION}

Massachusetts Department of Environmental Management

Commonwealth of Massachusetts

William F. Weld, Governor

A. Paul Cellucci, Lt. Governor

Executive Office of Environmental Affairs

Trudy Coxe, Secretary

Department of Environmental Management

Peter C. Webber, Commissioner 



\section{TABLE OF CONTENTS}

EXECUTIVE SUMMARY

INTRODUCTION

Mission

Management Planning Objectives

Regional Context

Overview of State Forests \& Parks

NATURAL RESOURCE MANAGEMENT

Forestry \& Wildlife Management 11

Fisheries 15

Rare Species \& Priority Habitat Areas $\quad 16$

Land Stewardship Zoning 16

Zoning Map 23

Carrying Capacity 25

Regional Open Space Conservation 30

LAKES \& PONDS

Background

Existing Conditions 35

Analysis $\quad 36$

Lake \& Pond Locus Map $\quad 37$

Lake \& Pond Descriptions and Recommendations 41

Beaman Pond 41

Lake Dennison $\quad 43$

Dunn Pond $\quad 44$

Laurel Lake $\quad \cdot \quad 46$

Sheomet Lake 48

Ruggles Pond $\quad 49$

Wickett. Pond 50

Regional Recommendations . 51

Swimming Suitability Assessment 51

Richards Reservoir \& Riceville Pord 52

RECREATION

Background $\quad 53$

Existing Opportunities $\quad 54$

GOALS Visitor Surveys

Sandler Associates Survey $\quad 56$

Visitor Attendance $\quad 57$

Attendance Graphs $\quad 58$

SCORP $\quad 60$

Management Goals \& Objectives 60

Recommendations 61

Maps: Erving Campground \& Wendell Cabins 62 
TRAILS

Background

Management Goals \& Objectives

Recommendations

Long-Distance Trail Map

Bed \& Breakfast List

STAFF ORGANIZATION

Current (FY 96) Staffing

Recommended Organization with Current Staffing Level

Enhanced Staffing Organization

Park Rangers

CAPITAL REHABILITATION \& IMPROVEMENTS BY PARK

Vehicles \& Equipment

Otter River

Lake Dennison

Birch Hill

Federated

Ware River Rail Trail

Gardner Heritage V.C.

Dunn Pond

Erving

Mt Grace

Warwick

Wendell

M\&M·Trail

Potential Long-range Recreation Improvements

ACKNOWLEDGEMENTS

REFERENCES \& SOURCES FOR ADDITIONAL INFORMATION

APPENDICES

A: Mass. State Forest Road Classification System

B: Fisheries Supplemental Information

C: Carrying Capacity

D: Gap Analysis Explanation

E: Park Visitor Survey Results

F: Millers River Recreation

G: Massachusetts Heritage Discovery Network

H: Greenway \& Trails - 1996 DEM Grants Recipients

I: Dam Descriptions \& Recommendations. 


\section{EXECUTIVE SUMMARY - ACTION PLAN}

This management plan is a first for the Department of Environmental Management (DEM) because, rather than covering a single facility as they have in the past, this plan examines all state forests and parks in eastern Franklin county and northwestern Worcester County. The planning area is mainly within the Millers River watershed, located in the state's central highlands, running northward from the Quabbin Reservoir to the New Hampshire border. The many forested hills and small mountains, the beautiful lakes and reservoirs, the brooks and rivers, and integrated areas of rural settlement, comprise an important scenic and recreational resource.

The state forests \& parks in the planning area provide a variety of rustic recreation facilities and large areas of scenic public conservation land. These are invaluable resources for a visitor's physical and mental well-being. Several ponds within the parks provide excellent opportunities for swimming, fishing and boating, for both day users and campers. Extensive trail systems within the parks connect to a regional long-distance trail, and conditions for winter recreation are exceptional. The parks covered in this planning area are relatively unknown treasures only an hour to an hour-and-a-half from Boston.

DEM plays an important role in the maintenance of biodiversity in Massachusetts due to the large amount of conservation land managed by the agency. There are more occurrences of rare species within the state forests and parks than are found with any other landowner, and the parks are also a stronghold for unfragmented interior forest habitat with viable. populations of native plants and animals. DEM forests and parks are therefore a foundation for ecosystem stewardship in this region. The regional planning focus is conducive to assessing ecosystem health as it is affected by continuity of habitat. Also, the regional focus of this plan supports the commonwealth's Watershed Initiative. Under the guidelines of the Watershed Initiative, a river basin or watershed is used as the fundamental planning area for integrated natural resource management. A watershed is defined as the geographic area within which surface and ground water flows to a common point. This forest \& park management plan will be one important component in the overall Watershed Initiative inventory and assessment for the Millers River basin.

The regional focus is effective for the assessment of various aspects of recreation such as the potential for longdistance trail connections, and efficient delivery of visitor services and the variety of associated management issues within a cluster of forests and parks. The parks within this study area are related to each other by proximity and by aspects of their natural, cultural and recreational resources. 
Otter River state Forest was the first state forest and campground, established by the Department of Conservation in 1915. The forest offers rustic facilities for family or group camping and water-based recreation at Beaman Pond. DEM leases the nearby Lake Dennison Recreation Area from the Army Corps of Engineers, providing opportunities for families or gatherings of friends to stay at one of 150 large wooded campsites. The scenic lake has good water quality and provides excellent opportunities for swimming, fishing and boating. Federated Women's club state Forest abuts the northeastern portion of the Metropolitan District Commission's Quabbin Reservation. This forest has several primitive camping sites, and is one of the most popular areas in the state for deer and turkey hunters. Scenic natural areas in this forest include the Fever Brook with surrounding wetlands and geologic features, and 140 acres set aside by deed restriction as a wildlife sanctuary.

Gardner Heritage state Park includes a visitor center in the heart of the city, located in a historic fire station. This is one of the state's most popular heritage parks, highlighting the history of the furniture and manufacturing industry and the city's cultural diversity. Dunn Pond state Park is located only a mile to the east, providing day use visitors with opportunities for swimming, fishing, boating and ice skating in a scenic setting. A major water quality improvement project was recently conducted for Dunn Pond by DEM working with the City of Gardner and a grant from the federal government.

Erving state Forest dates back to 1921 and was originally used as a nursery. The work of the Civilian Conservation Corps from 1933 - 1942 is still apparent in the headquarters area, the park roads, and the recreation facilities on Laurel Lake. This forest offers a wonderful opportunity for quiet family camping in 32 wooded sites, and the high quality lake provides the public with opportunities for swimming, fishing and boating. Mount

Grace state Forest in Warwick is important regionally for trail use with a trail system connecting to the 117-mile-long Metacomet - Monadnock Trail. The picnic area and playing field along Route 78 is also an important recreation resource for the local community. The nearby sheomet Lake in Warwick state Forest is used for fishing and is a scenic area visited mainly by local residents.

Wendell state Forest covers 7500 acres of scenic forested land south of the Millers River and includes an extensive trail system with connection to the Metacomet - Monadnock Trail. The Ruggles Pond swimming and picnic area is low-key, but very popular with local families who have become regular visitors.

The day use visitors come to these parks mostly from local communities or from locations along the Route 2 corridor. More than one-half of the campers are from the greater Boston area and other locations in eastern Massachusetts. They support the local economy through their patronage of grocery stores, restaurants and retail stores. There is a particularly strong connection 
between visitation to Gardner Heritage State Park and the Gardner area furniture outlets. A recent survey conducted for DEM by Richard Sandler Associates indicates that outdoor recreationists in the northeastern United States are seeking facilities with attributes of cleanliness and safety. They are hoping to find rustic yet functional recreation facilities and comfort stations, and the most important service that DEM can offer is a friendly and knowledgeable staff with ample information about the parks. DEM's stewardship of the forests and parks, and provision of recreation services, will continue to support the components of the local economy that are associated with tourism.

The management, improvement of facilities and development of goals is a dynamic process and several important changes occurred while this plan was in progress, including a new day use comfort station at Laurel Lake, a new comfort station for Beaman's campers, a new Clivus composting comfort station at Mt. Grace State Forest, and completion of the Universal Access Facilities project at Dunn Pond.

The GOALS team, working with DEM leadership, hopes that the plan will establish a vision for five to ten years in the future for this cluster of parks, bringing these facilities into the 21st Century and into DEM's 2nd century of land stewardship. The following recommendations are abstracted from the report as a priority action plan. The recommendations are intended to enhance recreation services and environmental protection while maintaining public safety and health, with a minimum of additional staff.

The parks in the focus area can be given a cohesive regional identity by using consistent signage, establishing a unique name for the cluster of parks, and producing a brochure to promote the cluster.

\section{STAFF ORGANIZATION}

One of the most important reasons for studying a cluster of several parks as a single management unit, is to be able to develop strategies for staff coverage and for shared use of vehicles and equipment that will promote the most efficient delivery of visitor services and management of park resources on a regional basis.

The proposed cluster organization would be more apparent in the winter with otter River as the headquarters for the cluster of parks. Erving and Gardner Heritage will be important satellites due to the significance of winter recreation and programs, with Erving covering the western end of the cluster. Crews for specific work projects will be organized out of otter River during the winter. Work projects will be conducted throughout the cluster as needed and will include road grading, trail maintenance, boundary work, structural rehab such as roof 
reshingling, snow plowing, picnic table construction, additional coverage for special events that generate large visitor attendance such as ice skating with bonfires at Dunn Pond, and for special needs such as carpool travel assistance when DEM vehicles require professional service station maintenance, and cleanup of illegal dump sites.

At the beginning of the winter staffing time period, priorities and timetable for work projects will be developed by the Regional \& Assistant Regional F\&P Director in coordination with cluster park supervisors. Priorities and work schedule will be updated at the monthly F\&P Regional staff meeting or as needed.

Addition of 2 Year-round Laborers as floating positions for the west end of the cluster (Erving/Wendell/Warwick), and addition of 2 Year-round Laborers as floating positions for the east end of the cluster (Otter River \& satellites/Gardner

Heritage) would allow:

- Increased ability to conduct road and trail maintenance on a regular basis.

- Strengthen productivtiy and increase scheduling flexibilitiy of proposed winter period work crews.

- The staff based at Otter River state Forest constructs picnic tables and provides signs for all of Region 4. This work is mostly accomplished in the winter. An additional Laborer position during the winter would benefit these regional projects.

- Increased provision of recreation services such as preparation for earlier opening and later closing for campgrounds, reopening the Mt. Grace field as a picnic area or reopening the toboggan - sliding hill, improved maintenance and availability of camping sites at Federated state Forest.

Addition of year-round laborer for Dunn Pond SP to cover additional maintenance responsibilities associated with the new universal access facilities.

Convert seasonal clerk to year-round position to cover campground reservations for Lake Dennison and otter River, and to assist with other work for the cluster.

Addition of 2 seasonal positions, summer workers or laborers, for each park that offers camping services would allow for overnight contact station coverage. ( 2 for Beaman/Dennison, 2 for Erving)

Addition of laborer for coverage of Mt Grace. Mt Grace is a locally important recreation area, which can not be adequately covered at the current staffing level. This would allow coverage for the picnic area and playing field in the summer and autumn, and for ice skating (playing field flooded in winter). 


\section{VEHICLE REPLACEMENT}

West end of cluster (Erving/Warwick/Wendell):

- Rack truck with snow plow

- Large tractor with all attachments

- Small vehicle (golf cart size) for comfort station maintenance

East end of cluster (Ot.ter River \& satellites/Gardner Heritage):

- Light truck with plow for GHSP

- Large tractor with all attachments

- Small vehicle (golf cart size) for maintenance of Dunn Pond universal access trail

- New industrial grade planer for sign construction

\section{CAPITAL REHABILTATION \& IMPROVEMENTS}

Facility rehabilitation and improvement is intended to enhance opportunities for visitors, while improving health and safety factors, and maintaining protection of natural and cultural resources. Priority projects include:

- Grading of park roads on a regular basis to ensure adequate access related to public safety and resource management is a priority of Forest \& Park and Bureau of Forest Development staff. Implementation would depend on establishment of dedicated funding for road grading materials from local gravel operations.

- Erving SF - Campground comfort station, power line and removal of vault toilet.

- Erving SF - Campground expansion (20+ sites).

- Otter River SF - Replace remaining vault toilet.

- Otter River SF - Rehab bathhouse - install 200 amp service, ADA upgrades.

- Otter River SF - Beaman Pond water quality improvement study \& implementation.

- Lake Dennison - Replace beach area bathhouse.

- Lake Dennison - Comfort stations upgrade.

- Wendell SF - Clivus composting toilets to replace vault toilets.

- Wendell SF - Cabin/yurt development.

- Wendell SF - Nordic ski center development.

- Wendell SF - Ruggles Pond water quality improvement project. 


\section{RECREATION}

DEM's management objective is to provide visitors with modern yet rustic facilities, and to enhance trail and other recreation opportunities in a safe, clean environment.

- Determine best alternative for enhancement of water-based recreation opportunities, to meet future increased demand.

- Establish nordic ski center and construct cabins/yurts for year-round use at Wendell SF, the most popular park in this cluster for nordic.skiing.

- Establish Adopt-a-Trail groups to work with each Forest Supervisor to establish more loop trails or improve existing loop trails within DEM properties.

- Trail maintenance \& volunteer coordination.

- Plan and implement small volunteer maintenance and construction projects to bring together the different user groups.

- Provide guides for trail etiquette on multiple use trails and for construction and maintenance that include the needs of various trail users to promote cooperation by helping user groups learn more about each other.

- Promote formation of advisory committees / friends groups for these forests \& parks.

- Provide support for trail interest groups (see Appendix H).

- Establish a long distance trail network to connect DEM and other conservation properties in this area, utilizing protected open space and unimproved town and county roads wherever possible. Focus on east-west trail connections.

- Increased demand for camping opportunities can be accommodated by expanding the Erving SF campground.

\section{REGIONAL OPEN SPACE CONSERVATION}

DEM's objective is to maintain a diversity of habitats within the forest \& park system, to sustain native plant and animal

diversity in Massachusetts, and to promote stewardship of public, private and nonprofit open space in support of this same goal.

- Determine if there is an interest in combining the efforts of EOEA agencies, Mount Grace Land Conservation Trust, Millers River Watershed Council, Athol-Orange Greenway Committee, Trustees of Reservations, Mass. Audubon, Army Corps of Engineers and the Harvard Forest to form a regional open space council. 
ENVIRONMENTAL EDUCATION \& COMMUNICATION

Environmental education is an important aspect of DEM's mission. The following text and recommendations are compiled from several portions of the plan to highlight the educational and interpretive components associated with the management of this cluster of parks.

A summary of the Sandler recreation survey indicates that historic appreciation and nature study are very popular activities in Massachusetts, having been mentioned by one-quarter to one-half of the respondents.

- FY 96 staff included Interpreters assigned during the summer months to Dunn Pond State Park, \& Lake Dennison Recreation Area.

- Otter River currently uses the services of the seasonal Park Interpreter assigned to Lake Dennison, but level of use justifies two separate seasonal Interpreter positions.

- Seasonal Park Interpreters should also be considered for Erving and Wendell in the future if additional positions become available.

- Interpretive trail(s) through recent timber operation sites can demonstrate Best Management Practices (BMPs) used in forest management. The harvesting site near the Wendell state Forest headquarters is one ideal area to establish this type of trail.

- DEM will coordinate with Northeast Utilities and DFW in the development of a forestry and wildlife management demonstration area at Northfield Mountain in Erving on 180 acres of property owned by Northeast Utilities and an abutting portion of Erving State Forest.

Forest management in the demonstration area will be aimed at supporting a diversity of native wildlife species.

Composition goals to support this objective are:

$5-15 \%$ seedling forest (trees <1" dbh),

30-40\% sapling-pole forest (trees 1-8" dbh),

40-50\% sawtimber forest (trees $>9 " \mathrm{dbh}$ ),

$5-10 \%$ large sawtimber forest (trees $>15 " \mathrm{dbh}$ ).

- All parks should consider installation of a short, self-guided interpretive trail.

- Place signs at trail intersections with a numbering system. Update trail map brochures with trail intersection numbering system, and provide brochures for trail users. Orientation wayside signs ( $\left.3^{\prime} X 5^{\prime}\right)$ should be considered for priority trailhead locations.

- Develop trailhead signs indicating the cooperative nature of the newly acquired Warwick conservation properties (DEM / Mount Grace Land Conservation Trust). Signs can be standardized with new carsonite markers. 
- Enforcement of DEM regulations and state laws will be enhanced through provision of information related to use of the parks:

- DEM will strive to improve communication and promote environmental education for our visitors.

- As of 1996, thirty five Forest \& Park Supervisors were authorized to write non-criminal citations. An additional group will receive the training in 1997. This authority is used in a non-confrontational and educational manner. The Park Rangers also provide educational programs and visitor services such as first aid and technical user information. The primary focus of a Park Ranger, in addition to their park supervisory responsibilities, are patrols for campgrounds, day use areas and trails, and visitor contact for educational purposes.

- Trails and ways may be posted closed to one or more use (s) with signs at trailheads, intersections, or prominent locations such as the forest headquarters or visitor centers.

- All parks should consider 3' X 5' "Welcome to..." orientation wayside signs for all main buildings.

- Install signs at all DEM-managed boat access sites encouraging boaters to remove plant debris before and after boats are launched, to reduce the spread of exotic and nuisance plants. Signs are available from the Public Access Board.

- Prepare a brochure in cooperation with DFW related to fishing opportunities along the Route 2 corridor. See example brochure for Myles Standish State Forest (Appendix B).

- Promote what DEM has to offer with marketing focus on the 'greater Boston area (only one to one-and-a-half hours away), thereby stimulating and strengthening the tourism aspect of the local economy.

- Communicate with publishers of travel guides (AAA, Mobile, etc.) to expand coverage of state park opportunities.

- Increase availability of brochures and information on special events in Chambers of Commerce, Offices of Travel \& Tourism, and along highway stops in neighboring states.

- Promote the excellent trail opportunities and scenic / interesting stops along trails.

- Coordinate with the Millers River Watershed Council to promote and provide more public access to the river. The Route 2 corridor westward from Wendell can be promoted as a canoe route with access to the Millers River from Wendell State Forest or other points. With a portage at the Turners Falls Dam, canoeists can access Connecticut River Greenway State Park and canoe path. A list and map of river access sites from the 1983 Millers River Management Plan is included in Appendix F. 
- Historic and cultural sites within the state forests might be appropriate for interpretive programs that could be marketed in the region or statewide. Potential sites within this cluster of parks include:

- Native American sites such as prehistoric villages, a Colonial Period tribal council meeting location, camp locations.

- Mill, tannery and house sites from the Colonial through Industrial Periods (late-1500s thru early-1900s).

- Civilian Conservation Corps sites.

Note: A professional determination of the significance and integrity for any historical or cultural site, with development of a treatment/protection plan, would be required prior to establishing public visitation procedures.

- The Heritage Discovery Network database, developed by DEM's Office of Historic Resources, provides an avenue for DEM to increase the public's awareness of natural, scenic, cultural and historic attractions of Massachusetts. The Network has a unique focus on "second tier" heritage attractions--those sites which are most often missed in conventional tourist promotion. The database includes detailed information on sites in Franklin County along the Mohawk Trail. As additional sites are added to the database, and the data availability becomes more tourist-user friendly, DEM should take full advantage of this new tool to promote recreation opportunities for this cluster of parks. The database is accessible at the Great Falls Discovery Center in Turners Falls. The sites that are currently covered in the database are listed in Appendix G.

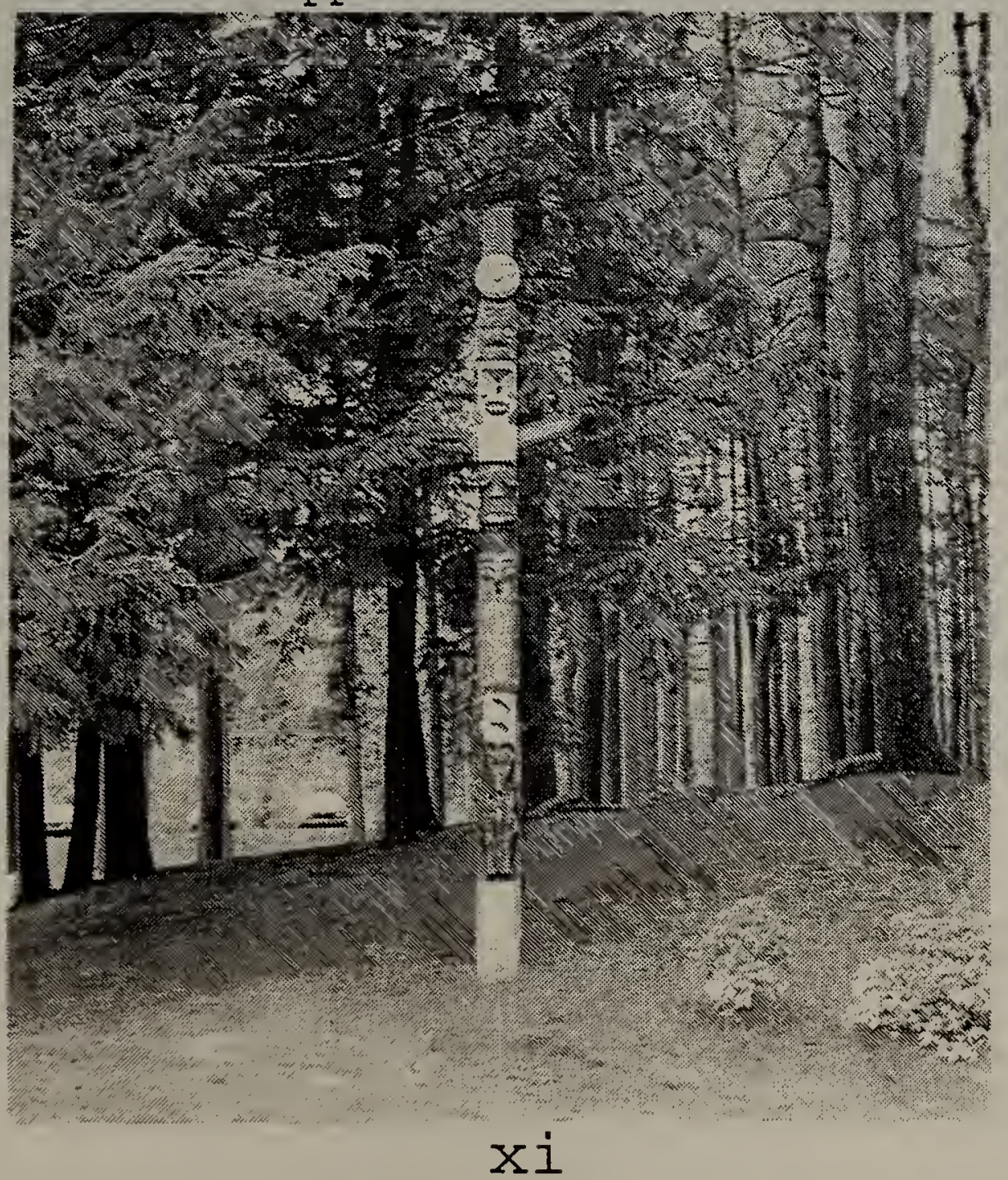




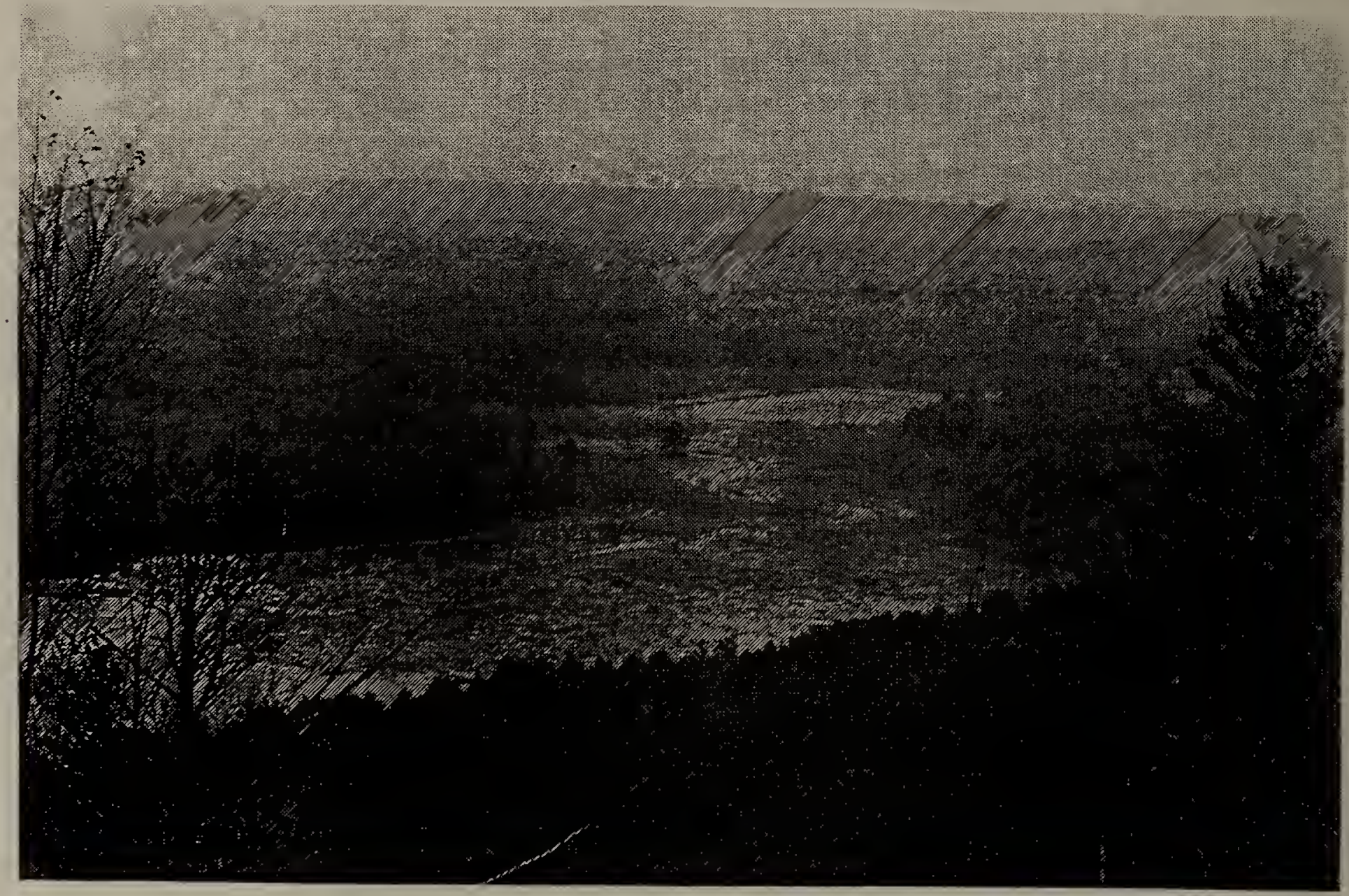




\section{INTRODUCTION}

\section{MISSION}

The Department of Environmental Management (DEM) exercises care and oversight for the natural and cultural resources of the Commonwealth, and provides quality public recreational

opportunities in the state forests \& parks. DEM's GOALS Program (Guidelines for Operations And Land Stewardship) provides the means for DEM to develop management plans that cover all aspects of recreation and resource management for the state's parks.

The GOALS planning process brings together a primary team of individuals made up of the Park Supervisors, Assistant Regional and Regional Forest \& Park Directors, Management Foresters and GOALS Program Planners. A secondary team is often composed of individuals from within DEM, and also professionals from other state agencies, who contribute their expertise. Public input is also a very important component in the GOALS planning process. Over the past ten years GOALS management plans have been completed for 20 parks across the.Commonwealth, covering over 100,000 acres of public land, addressing parks with a great deal of diversity related to size of the facilities, the variety of natural and cultural resources, and elements of visitor use.

This GOALS plan is a first for DEM because, rather than covering a single facility as they have in the past, this plan examines all state forests and parks in the northern portion of DEM's administrative Region 4 (eastern Franklin County and northwestern Worcester County). This cluster of parks is chosen because of the potential for enhanced delivery of recreation services and resource stewardship, resulting from the cooperative use of the management capabilities of several related facilities. DEM's Division of Forests \& Parks and the Division of Resource Conservation are working together on th pilot regional planning initiative covering nine state forests and parks and their associated satellite properties; Otter River state Forest, Lake. Dennison Recreation Area, Federated Women's Club of America state Forest, Gardner Heritage State Park, Dunn Pond State Park, Erving State Forest, Mount Grace State Forest, Warwick state Forest and Wendell state Forest. The GOALS plan describes existing conditions for a variety of resources that are associated with this cluster of parks. The descriptions include an examination of management concerns and opportunities, which helps to clarify issues, leading to the development of action recommendations.

\section{MANAGEMENT PLANNING OBJECTIVES}

The new regional planning orientation is intended to provide DEM more effective ways to address the delivery of visitor services and a variety of associated management issues within several forests and parks. These parks are related to each other 
by proximity, and by aspects of their natural, cultural and recreational resources. The regional perspective will also allow DEM to work with nonprofits, municipalities, state and federal agencies, to enhance the continuity and protection of open space, and identify long-distance trail connections.

Regional planning activities of the Commonwealth are being conducted with focus at the watershed or river basin level, under the guidelines of the Watershed Initiative. A watershed is a geographic area within which surface and ground water flows to a common point. By making the watershed the context for decision making, regional aspects of natural resource management can be considered in environmental assessment and planning, and implementation of conservation and restoration strategies.

The focus region for this plan drains to the connecticut River via three major tributaries, but is mainly within the Millers River watershed (see watershed boundary - page 119). The northwestern portion of this region is in the Ashuelot River basin, which joins the Connecticut River in New Hampshire, and the southern portion of the region is within the Chicopee River basin. The focus region can be described as the state's central highlands, located in an area north of the Quabbin Reservoir and south of the New Hampshire border. The many forested hills and small mountains, the beautiful lakes and reservoirs, the brooks and rivers, and the integrated areas of rural settlement, comprise an important scenic and recreational resource only an hour to an hour-and-a-half from Boston, and one-half to one hour from Springfield. The more densely populated communities in this region include Orange, Athol and Gardner.

Although this region was hit quite hard by the recent recession, the residents are proud of a hard working, productive heritage in a variety of mills, manufacturing, and natural resource-related industries. A promising direction for sustainable economic growth in the area is in the recreation and tourist industry, balanced with the importance of conserving and enhancing natural and cultural resources which define the region.

\section{REGIONAL CONTEXT}

The landscape is characterized by the most rugged terrain of the state's central upland. Elevations range from 200 to 1500 feet above sea level. Residual hills composed of erosion resistant rocks, also known as "monadnocks", are an important component of the landscape in this region, and northward into the southern portion of New Hampshire.

The bedrock in this region is overlain in most areas by shallow to deep glacial deposits, and the soils derived from this glacial parent material are generally acidic and range from rocky, well-drained sandy, gravelly loams, to poorly drained 
mucks rear the water table. The presettlement forest was probably composed of a variety of transition hardwoods including oak, hickory, chestnut, beech, birch, maple, ash and cherry, with white pine and hemlock adding to the variety of cover types.

Recent research indicates that variation in vegetation cover type over large regions is most strongly affected by climate. Effects of surficial geology, topography and disturbance history are also important factors influencing vegetation diversity.

Native Americans settled mainly along the water courses including the Millers River where salmon and trout were abundant. These original settlers also hunted and trapped the variety of wildlife that was present in the rich ecosystem, and later established an agricultural society utilizing the deep floodplain soils near the river. The Nipmuck Tribe was displaced from this region by the European settlers. The first permanent white settlement was established in 1735 in what is now Athol.

Much of the forest land was cleared during the mid- to late1700s and early-1800s so that the area could be used for pasture and crops. The lumber was used for building materials and firewood. The river provided power for small mills and then for industries that became established during the 1800s, shifting the residents' livelihoods from agriculture to manufacturing. The region has gradually reforested since that time. The variety of soils, topography and historic land use provides a mosaic of site conditions that is revealed in the current pattern of vegetation cover types.

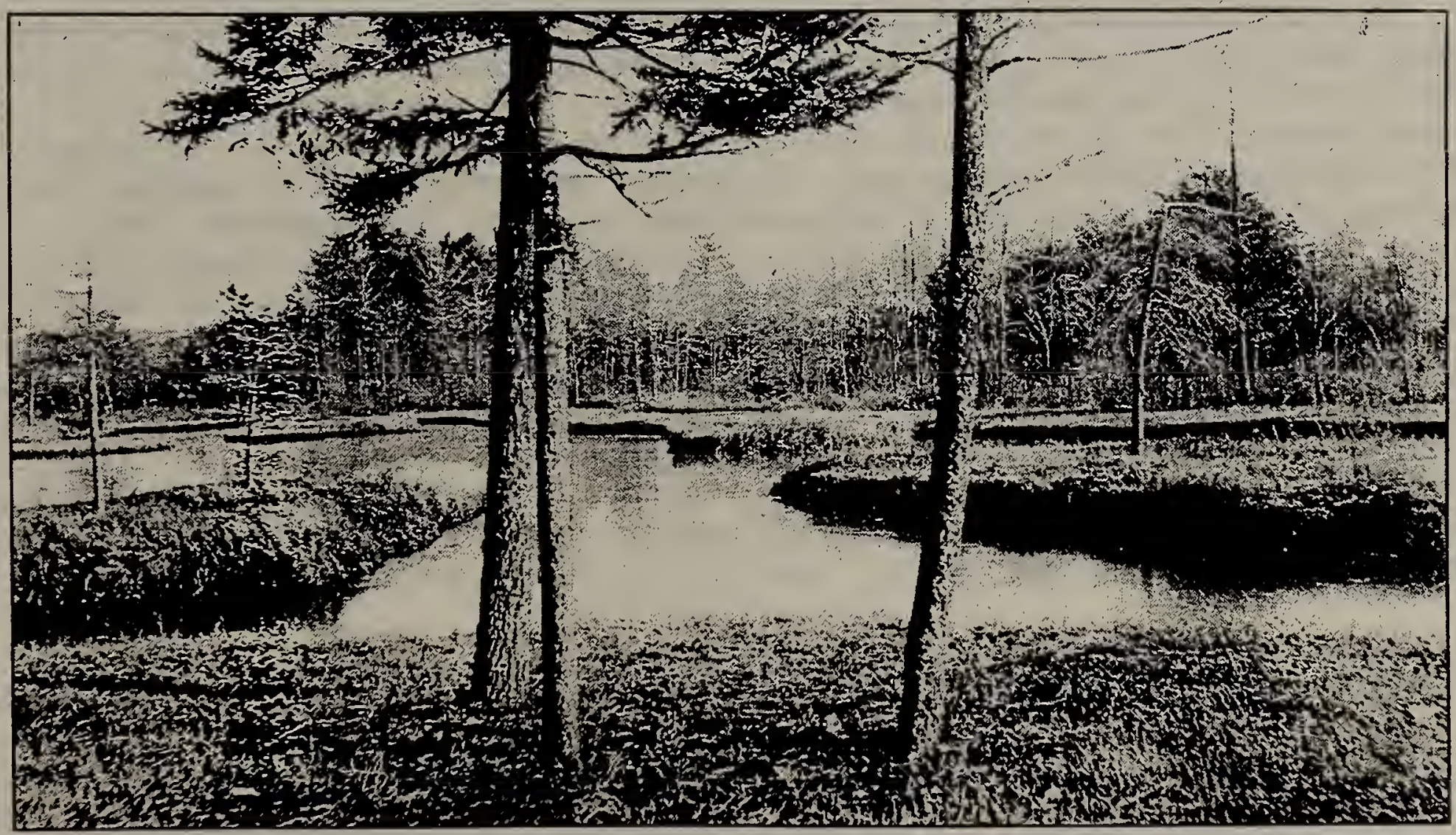

DUNN PARK - This photo taken in 1917 for postcard use depicts Dunn Park as it appeared at that time. 
Otter River state Forest (ORSF), acquired by the Commonwealth in 1915, was the first state forest and the first campground established by DEM, at that time known as the Department of Conservation. The state forest is located in Templeton and Winchendon and covers approximately 1220 acres. Recreation facilities include 100 campsites, three group sites, two swimming beaches, a pavilion, and a ball field, all located next to Beaman Pond. The otter River headquarters, garage and maintenance facilities are located within this state forest just off of Route 202, in Baldwinville within the Town of Templeton, near the Winchendon town line. DEM's Bureau of Fire Control District 8 is partially headquartered in the ORSF management unit.

The U.S. Army Corps of Engineers (ACOE) owns a substantial acreage of floodplain and wetlands surrounding otter River, known as the Birch Hill Flood Control Area. The primary purpose of Lake Dennison, located just to the north of ORSF in Winchendon, is flood control, but DEM has a 50-year lease (current lease expires in 2026) to use Lake Dennison for recreation and fish \& wildlife management purposes. DEM leases 4221 acres from ACOE at this site, and in turn DEM leases about 4000 acres of that to the Massachusetts Department of Fisheries and Wildlife (DFW) for purposes of fish and wildlife management. DEM manages the $200+$ acre Lake Dennison Recreation Area day use and camping areas, including 150 campsites, a swimming beach and picnic area.

The several square miles of open space covered by the state forest and ACOE lands provides the public with wonderful opportunities for dispersed recreation. The abundance of undeveloped, forested land also provides vital habitat for game and nongame wildlife species. Hunting is a popular activity in season, and an extensive trail system is used throughout the year. The park staff maintains many mles of forest roads for dog sledders, nordic skiers and snowmobilers. The trails are also maintained for warm weather uses such as hiking, horseback riding and mountain biking. Lake Dennison has $\mathrm{pH}$, oxygen and temperature conditions that allow for a put-and-take trout stocking program administered by Division of Fisheries and Wildlife. Fishing is popular throughout the year. Also, the DEM staff organizes a smaller scale fishing program for children camping at Beaman Pond. 
There are several areas of public open space, either with primitive facilities or without any type of developed facilities, that are managed by the ORSF staff.

The 984 acre Federated Women's Club state Forest

(Federated), located mostly in Petersham with some acreage in New Salem, abuts the northeastern portion of MDC's Quabbin watershed

Reservation. A 140-acre block within the forest is set aside by deed restriction as a wildlife sanctuary where hunting and trapping are prohibited. Federated is an extremely popular site for deer and turkey hunters. Throughout the summer and fall, six primitive camp sites are available for people who enjoy camping in uncrowded natural conditions. Campers are required to check in at the otter River headquarters prior to setting up camp.

State Forest land totaling approximately 4500 acres, or about seven square miles of open space, is located in many separate parcels including Winchendon state Forest, Templeton State Forest, Petersham State Forest and Riceville Pond, Hubbardston State Forest, Royalston State Forest, Athol State Forest and Lawton State Forest in Athol. The areas comprise a valuable resource for a variety of trail uses, hunting, trapping and fishing, and are also important habitat areas for wildlife, natural filters that improve the quality of surface and groundwater, and sources of forest products. Natural areas such as the Fever Brook Gorge in Federated, Riceville Pond. in Petersham State Forest, and the many streams, wetlands and diversity of upland sites dispersed throughout the blocks of state forest land are important components of the region's outstanding scenic attributes.

The ware River Rail Trail is a 15-mile-long corridor, which runs north-south along a former railroad Row through portions of Templeton, Phillipston, Hubbardston and Barre. The Rail Trail is an undeveloped multi-use trail managed by the ORSF staff.

Gardner Heritage state Park is made up of two separate facility components, along with a variety of educational and cultural programs. The Heritage state Park visitors Center, located in the center of the city in an historic fire station, highlights the history of the furniture manufacturing industry and the city's cultural diversity through exhibits, displays and programs. The Heritage state Park has contributed to the area's economic stability by providing information and thereby increasing interest in local furniture outlets and other businesses. The staff has also organized a series of band concerts and helps to maintain flower planters located around the downtown area.

Dunn Pond state Park was a city-managed recreation area for many decades. In the early- to mid-1980s, DEM with the City of Gardner and a grant from the federal government, conducted a major rehabilitation project that included lake improvement through dredging and filter dam construction, and constructing new headquarters / meeting space / comfort station facilities. A large parking area has recently been paved to improve access to 
the site. This day use facility has a very popular swimming area, large wooded picnic sites, and an exercise trail around the perimeter of the pond. The Park is an important recreational site year-round because the staff clears snow from a portion of the pond for ice skaters and organizes cultural events such as Native American programs, and outdoor activities such as bonfire skating parties and ice fishing derbies. The Division of Fisheries and Wildlife stocks the pond with trout. The deed for Dunn Pond has recently been transferred from the city to DEM, and DEM has completed a universal access improvement project at the site. Additional site improvements are upcoming. Funding comes in part from the federal Land \& Water Conservation Fund (LWCF) Program via the Commonwealth's Division of Conservation Services.

Erving state Forest (ESF) and the contiguous Northfield state Forest cover over ten square miles in Erving, Northfield, Orange and Warwick. The ESF headquarters and a central office for District. 9 Fire Control are located just south of Route 2 in Erving. Most of the state forest land, including the beautiful Laurel Lake camping and day use area, runs northward from Route 2 nearly to the New Hampshire border. The Laurel Lake recreation area within ESF is located in Erving and Warwick and includes a 32-site camping area, picnic sites and the most popular public swimming beach in the area. Laurel Lake is also popular for boating and fishing, enhanced by the DFW trout stocking program. The large area of rugged forested land that comprises the remainder of these state forests is used for hunting, trapping, fishing and a variety of trail activities during all seasons.

Just to the north of Warwick center along the western side of Route 78, the headquarters for Mt. Grace state Forest is located next to a picnic area and playing field. A trail system originating at the headquarters and field area traverses the steep topography of this 1690-acre state forest, with pathways connecting to the Metacomet - Monadnock Trail and leading to the top of Mt. Grace - elevation 1625' ASL.

The Metacomet - Monadnock Trail is a 117-mile-long hiking trail, stretching from Mt. Monadnock in New Hampshire to its southern terminus in Connecticut. The trail corridor provides a link between several of the state forests covered in this plan. Hikers passing through eastern Franklin County traverse portions of Wendell, Erving, Northfield, Mt. Grace and Warwick state

Forests. The significant amount of trail mileage located within state forest. properties has generated a close working relationship between DEM staff and Appalachian Mountain Club ( $A M C$ ) volunteers and other groups who help maintain the trail.

Several parcels of state forest land are located within the Town of Warwick. Totaling over 7000 acres, they are known collectively as warwick state Forest. This Forest includes Sheomet Lake, a high quality impoundment that is stocked by DFW, 
with potential for recreation area development in the future. The Warwick Carpentry Shop is also located within the state forest. In recent years, the carpentry shop supplied the Forests \& Parks in Region 4 with signs, picnic tables and other facility needs. A Correctional Camp was formerly associated with DEM's carpentry shop, supplying staff for various construction and work projects.

A recent land acquisition effort, conducted by DEM in partnership with Mount Grace Land Conservation Trust (MGLCT), has conserved an additional 492 acres of open space, linking a large tract of Warwick state Forest with MGLCT's Arthur Iversen Conservation Area. Acquisition of the Earle, Maynard and Zellmer properties was completed in June 1995. Please refer to Figure 1 related to the following description. DEM acquired, in fee, the southern 108 acres, which is adjacent to a portion of Warwick State Forest, and includes Gales Pond. DEM purchased a conservation restriction on the remaining 384 acres owned by MGLCT, and MGLCT granted a conservation restriction to DEM over 128 acres of the Arthur Iversen Conservation Area. The project is part of a larger effort by DEM and MGLCT to link several parcels of Warwick state Forest with other protected land in the area.

The newly acquired property is quite diverse with narrow valleys, steep slopes, and a variety of water resources including the 11-acre Gales Pond, portions of Hodge and Rum Brooks and their substantial associated wetland systems, an outstanding black spruce bog, several vernal pools, and a seasonal cascade known as the Devil's Washbowl. Wildlife and vegetation surveys were recently completed by professional natural resources consultants.

The current uses of conservation land in this area include trail activities, hunting and forestry. Snowmobiling is the most popular trail activity in the DEM properties in Warwick, and the state forest land is also used for horseback riding. People using the trails on foot are mainly residents of Warwick who live near the properties. Trails in the Arthur Iversen Conservation Area are used mainly for hiking, and the northwestern portion of the new property is less than a mile from the Metacomet-Monadnock Trail. The DEM-managed parcels are also used extensively for hunting. This use is particularly prevalent in the Allen Road area.

DEM has conducted two recent timber sales, an oak leaf tier salvage cut in the Allen Road area, and a shelterwood cut in the Beach Hill Area. Land acquired by MGLCT in 1990-93 is available for timber harvesting, but there is not much merchantable timber on the properties at this time. MGLCT has a cutting plan for these areas. MGLCT will restrict timber harvesting on a portion of their land, including the Devil's Washbowl area and all sensitive areas that are identified in the wildlife inventory report. 


\section{FIGURE}

Mt Grace Land Conservation Trust/Dept of Environmental Mgmt Public/Private Partnership Project Arthur Iversen Conservation Area/Warwick State Forest

Gale Road, Warwick

$\square$ Owned \& Managed by MGLCT/Conservation Restriction Held By DEM Conservation Restriction Held by MGLCT/Privately Owned

Department of Environmental Management Warwick State Forest

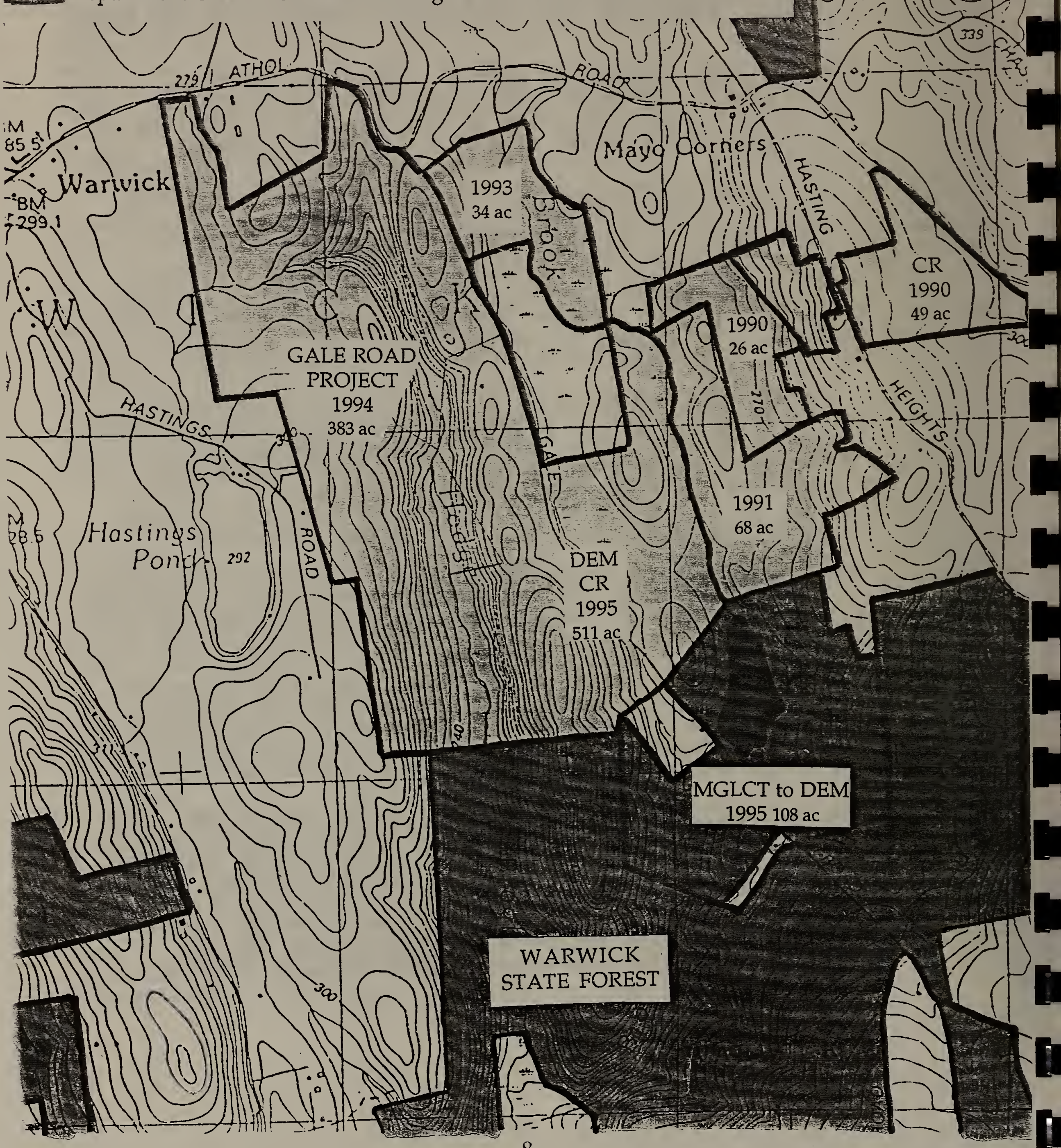


Management concerns for both DEM and MGLCT include trash dumping and restriction of ORV and 4WD access. DEM will continue to work with MGLCT to clarify and address management issues that can be addressed cooperatively. Recommendations related to trail connections between DEM and MGLCT properties and other trail considerations are included in the Trails section of this plan.

South of the Millers River and the Route 2 corridor, mostly within the Town of Wendell, Wendell state Forest covers over 7500 acres of forested hills, with streams, ponds and wetlands, and includes an extensive trail system. The park headquarters is located on Montague Road. The park entrance next to the headquarters leads the visitor down a short hill to the scenic Ruggles Pond day use area. The water is clean, but tea colored due to humic acids from the organic sediments and runoff from the surrounding forest. The swimming and picnic area is low-key and quiet, but very popular with local families who have become regular visitors. There is also a ballfield with a pavilion located nearby along another portion of the pond's shoreline. A boat access for car top boats is located on Wickett Pond, a scenic natural pond about a mile east of Ruggles Pond, also accessible through state forest roads from Montague Road.

DEM and Mount Grace Land Conservation Trust have been working together to expand Wendell state Forest. In June, 1996 an acquisition was completed for several parcels totaling 346 acres. In a separate transaction a 57-acre conservation restriction was acquired, linking the newly acquired 346 acres to Wendell state Forest. The property includes a large section of Bear Mountain with valuable forest land, excellent wildlife habitat, and several streams including a brook with a cascading waterfall. The entire piece is within the viewshed of the Millers River and includes some steep slopes adjacent to the river. The area is noted for its interesting geologic features such as an impressive $30+$ foot cave near the highest elevation. The many woods roads will add to the state forest trail system.

Similar to the eastern end, the western end of this central highland grouping of state parks has several blocks of state forest land without any developed facilites. These blocks include Orange State Forest (59 acres), Shutesbury state Forest (845 acres), and additional DEM-managed land in New Salem, Leverett and Montague. These areas of open space provide continuity of habitat for wildlife, and opportunities for dispersed recreation. 


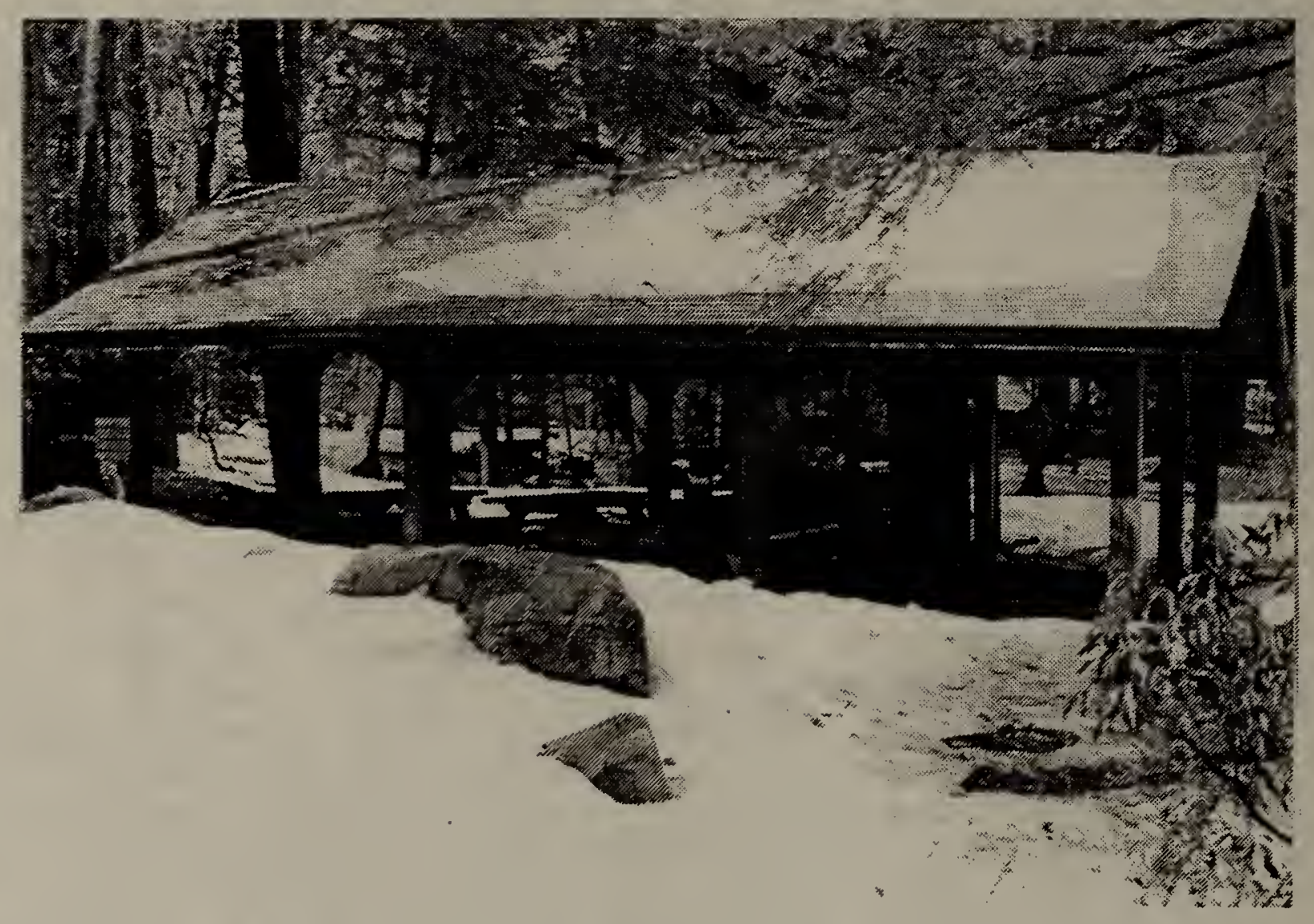




\section{NATURAL RESOURCE MANAGEMENT}

\section{FORESTRY \& WILDLIFE MANAGEMENT}

DEM's forestry activity within the state forests and parks is intended to provide marketable forest products while enhancing habitat for the widest possible variety of native wildlife species. Spin-off benefits, such as road grading accomplished by the loggers, improve access for park management and emergency vehicles, and improve opportunities for dispersed recreation (Appendix A - forest roads classification).

The forest products industry is an important component of the economic stability in the north-Quabbin region. In support of this industry, DEM Management Foresters market up to 500,000 board feet of timber per year from the state forests and parks covered in this plan. Also, under DEM's Home Fuelwood Program, the state forests provide more than 200 cords/year used for heating local homes. This Program allows people to bid on lots for a supply of fuelwood for personal use.

Wildlife management for multiple species (nongame and game) requires consideration of local landscape conditions in combination with special features that require specific management such as spring seeps, vernal pools and other wetlands, den and cavity trees, abandoned orchards, and deer wintering areas. The forest cutting plans developed by DEM foresters take these factors into account in order to maintain and enhance the variety of wildlife habitat. The importance of this land stewardship ethic is represented by a recent publication produced by the Principal Research Wildlife Biologist from the Northeastern Forest Experiment station located at UMass-Amherst, in cooperation with one of DEM's north-Quabbin area Management Foresters. The publication, Forest Wildlife of Massachusetts: Cover Type, Size Class, and Special Habitat Requirements, by Richard M. DeGraaf and David M. Richard, identifies habitats utilized by Massachusetts wildlife, and is intended for foresters and landowners interested in improving the diversity of wildlife through forest management. The publication is available through the Cooperative Extension Service at UMass.

DEM and the Department of Environmental Protection Division of Wetlands \& Waterways recently cooperated to revise the Massachusetts Forest Cutting Practices regulations ( $\mathrm{Ch} .132$ ) and the forestry section of the Wetlands Protection Act regulations (Ch. 131). The revisions are intended to enhance the protection of wetlands during timber harvesting operations through the use of Best Management Practices. Public interests that are positively affected by the revised regulations include conservation of water quality and quantity, prevention of floods and soil erosion, improving habitat for wildlife and conditions for recreation. 
DEM Management Foresters use the Field Manual for Silvicultural Prescription, a system derived from A Forest Land Classification System for Massachusetts by Mawson, Rivers and Fischer, to assemble information about forest characteristics of the DEM forests and parks, in order to prescibe site-specific management and silvicultural treatment recommendations. Information on stand analyses and silvicultural recommendations is available at DEM's Regional Forest \& Park headquarters in Amherst. DEM Foresters also have a key role in the long-term research of the Continuing Forest Inventory (CFI). As funding becomes available, the permanent plots in Massachusetts will be resampled and the inventory will be used to set management guidelines such as the planning of allowable cut.

The state forests \& parks in the north-Quabbin region are an important resource for hunters, trappers, and people interested in wildlife viewing. DEM cooperates with the Mass. Division of Fisheries \& Wildlife (DFW) reiated to the DFW Licensing and Permit Program for hunting and trapping and the DFW stocking program for game birds. Hubbardston state Forest was the original release site for turkey reintroduction east of the Connecticut River. This program has been very successful, with a healthy turkey population now established in northern worcester county and statewide.

Staff from Shade Tree Management \& Insect Pest Control within the Bureau of Forest Development periodically conduct a hazardous tree survey in the parks high use areas, and remove branches or trees that present a public safety hazard. The regional STM\&IPC crew also monitors trends in insect populations such as gypsy moth, which can adversely effect the forest in this area by defoliating and weakening the trees.

Members of the Massachusets Legislature, working with forest resource specialists, have established a proactive agenda for efficient utilization and conservation of forest resources. Senator Wetmore lead the way by successfully proposing legislation that initiated a Special Commission on Forestry Management Practices. The Commission is charged with seeking ways to better utilize "under-utilized" wood currently found in abundance in the Commonwealth's forests, while at the same time creating healthier and more valuable public and private forest land, and improving wildlife habitat.

Intitial recommendations include:

- A call for the Legislature to fund an updated Continuous Forest Inventory (CFI). The CFI provides vital data on the state's 285,000-acre public forest and park system, including the volume of timber by species, and the health and growth rate of the timber. CFI had its beginnings in the mid-1950s with a collaboration between the Department of Conservation (now DEM), the USDA Forest Service, and the University of Massachusetts Department of Forestry \& Wildlife Management. The plots have 
been measured on three occasions, but the most recent survey was $1977-78$.

- The Commission drafted legislation, which directs the purchasing agent of the Commonwealth to establish a preference, whenever possible, in favor of electricity produced by "woodfired" electric generation facilities. The Commission recommends that the Legislature adopt this legislation to encourage more state involvement with woud energy. The timing of the ongoing electric power industry deregulation increases the opportunity to promote the importance of wood as a source of energy.

- The Commission was instrumental in initiation of a large-scale wood energy pilot project at Mt. Wachusett Community College in Gardner. A Forest Products Education and Development Center has been established at the college to provide support for the pilot project and to promote wood products information marketing, education and training. The Commission is also hoping to initiate a wood energy pilot project to convert the energy system for the Athol-Royalston high school.

- The Legislature has included \$5 million in the Transportation Bond Bill for a Wood in Transportation Pilot Project, which will utilize DEM \& MDC properties as demonstration sites to promote wood utilization for vehicular and pedestrian bridges, guard rails, sign posts and retaining walls. The ultimate goal of this pilot project is to improve access for recreation, park management and harvesting of under-utilized wood resources. - The Commission is researching the protection of old growth forests. The vehicle for this could potentially be legislation to amend the state's Endangered Species Act.

- The Commission has several important issues on the agenda for continuing study and work, including manufacturing applications for under-utilized wood, the potential for redirecting state and local revenue streams to encourage a heightened degree of forest management activity, legislation to provide incentives for private landowners to undertake forest management activities, and research related to long-term sustainability of forest resources. 
Recommendations:

- DEM will coordinate with Northeast Utilities and DFW in the development of a forestry and wildlife management demonstration area at Northfield Mountain in Erving on 180 acres of property owned by Northeast Utilities and an abutting portion of Erving state Forest.

Forest management in the demonstration area will be aimed at supporting a diversity of native wildlife species. Composition goals to support this objective are: $5-15 \%$ seedling forest (trees <I" dbh) 30-40\% sapling-pole forest (trees 1-8" dbh), 40-50\% sawtimber forest (trees $>9 " \mathrm{dbh}$ ), $5-10 \%$ large sawtimber forest (trees $>15 " \mathrm{dbh}$ ).

- Silvicultural recommendations to increase land area at either end of the successional spectrum.

- Suitable areas for bird and lepidoptera species that require open field habitat are in short supply in Massachusetts. A variety in the distribution of successional stages across the landscape, including a greater acreage in open field and early sucessional forest, can be established by rotating clearcuts up to 40 acres in size in selected areas of the state forests. This treatment would be applied to stands with low timber value, such as beech and low quality oak. A few large patches rather than a lot of small patches would be more beneficial for these wildlife species. Coarse woody debris should be maintained as ground cover in the clearcuts to provide wetter, cooler refuge areas for amphibians.

Patches should be located so that continuity of interior forest habitat can also be maintained. Increase in cutting would also improve economic opportunities for local timber harvesters.

- A recent study indicates that there is very little old growth forest in Massachusetts. Selected late-successional forest stands should be allowed to progress toward longer rotations to simulate old growth conditions.

- The Federated Women's Club purchased land from the Diamond Match Company and donated the nearly 1000-acre Federated State Forest to the Commonwealth in 1933. A deed restriction exists for a 140-acre wildlife sanctuary within Federated, which is one of the most popular DEM forests for hunting. Coordination with DFW is needed to ensure that hunting and trapping at Federated occurs only outside the boundaries of the wildlife sanctuary. 


\section{FISHERIES}

The lakes and ponds within the state forests and parks in the north-Quabbin area support natural fish populations with a variety of species including largemouth and smallmouth bass, chain pickerel, pumpkinseed, bluegill, yellow perch, golden shiner, brown bullhead, banded killifish, and American eel. These species are important in the stability of the lake ecosystems and also help sustain the sport fish that are stocked by the Division of Fisheries and Wildlife (DFW).

DFW fisheries management focuses on a catchable trout stocking program for Dunn Pond, Lake Dennison, Laurel Lake and Sheomet lake. These lakes and ponds along the Route 2 corridor make up one of the most important fishing resources in the Commonwealth. Boat, shoreline and ice fishing are popular activities in these recreation areas. Fishing derbies held at Dunn Pond have attracted as many as 1000 visitors.

Dunn Pond is annually stocked with over 1000 brook trout. In addition, about 1200 trout averaging six inches in length were recently released to relieve overcrowding at the fish hatchery. Lake Dennison is stocked with about 1200 brook, brown and rainbow trout in the spring and about 500 rainbows in the fall. Over the past ten years, Laurel Lake has been annually stocked with 1500 to 5000 rainbow, brook and brown trout, although brook trout have not been stocked since 1992. Sheomet Lake has also been stocked with rainbow, brook and brown trout. 1300 to 2600 fish have been annually stocked, but brook trout have not been part of the mix since 1990. DFW collects data on $\mathrm{pH}$ level and acid neutralizing capacity on an annual basis as part of the trout stocking program.

Wickett Pond in Wendell state Forest is not stocked by DFW, but it is a popular fishing site, particularly for ice fishing. opportunities to catch bass and perch bring visitors to wickett.

Recommendations:

- Continue cooperation with DFW Central and CT Valley District stocking programs. Stocking to occur at or near current (1995) levels unless water quality or demand changes.

- Continue to survey the fish communities and water quality parameters in the lakes and ponds in order to gather information needed to guide management decisions.

- Coordinate'with DFW and DEP for use of lime to maintain pH at a level to sustain healthy populations of trout and other fish species.

- Encourage harvest of warmwater species to increase the health of stocked fish.

- Prepare a brochure in cooperation with DFW related to fishing opportunities along the Route 2 corridor. See example brochure for Myles Standish State Forest (Appendix B). 
Franklin County is ranked second among Massachusetts counties related to diversity of rare species. Although most of the rare species are clustered around the connecticut River, there are also important rare species habitat areas located within the state forests throughout the north-Quabbin region. Due to the large amount of conservation land managed by DEM, there are more occurrences of rare species within the state forests and parks than are found with any other land managing agency or landowner. This translates to a very important stewardship role for DEM related to protection of the state's rare natural resources.

For DEM forests and parks in the north-Quabbin area, detailed information on occurrence of rare species or community types, location of habitat, and specific management guidelines are kept on hand at the local forest \& park headquarters and the regional forest \& park headquarters in Amherst.

DEM staff will continue to coordinate with the DFW Natural Heritage \& Endangered Species Program to protect rare and endangered species habitat and unique communities within the state forests \& parks. Sensitive habitat areas will be managed under the guidelines of the Environmental Protection Zone from the Land Stewardship Zoning system which is explained in detail in the following text.

\section{LAND STEWARDSHIP ZONING}

A Land Stewardship Zoning system has been developed by all the land managing agencies within the Executive office of Environmental Affairs, $i . e$. the Department of Food \& Agriculture; the Department of Fisheries and Wildlife; the Metropolitan District Commission; and the Department of Environmental Management. The system is intended te increase the consistency of management across all state-owned conservation land, and to improve interagency cooperation, especially in areas where two or more state agencies manage closely related properties.

The zoning classification system guidelines make it possible to regulate activities within certain areas so that sensitive and significant resources are protected. In addition, it is possible to guide future development and improvements to sites that can tolerate intensive use. 
ENVIRONMENTAL PROTECTION ZONE: Highly sensitive areas requiring a high degree of protection, such as steep erodible slopes, unique wetland areas, or fragile archeological sites are within this zone.

\section{Recreation}

- Only low impact activities permitted in this zone, including dispersed and normotorized recreation.

- Intensive, development-dependent recreation not permitted.

- New trail construction permitted if limited to stable areas and located to avoid adverse impacts to rare species, and known or potential archaeological sites.

Visual Resources

o Retain area in natural state or preserve and enhance existing natural or cultural landscape.

- Minimal cutting to maintain or enhance vistas permitted. Vegetation \& Wildlife Habitat

o Intensive habitat manipulation not permitted except as recommended under the following guidelines.

- Natural Heritage \& Endangered Species Program recommendations used to restore, maintain and enhance habitat of rare and endangered species, and rare exemplary communities.

- Research which causes no adverse impact to sensitive resources will be permitted through a formal written proposal. process, approved in advance by the Director of Forests \& Parks or his designee.

- Vegetation management allowed: Under habitat management plan utilizing native species to control erosion, for stabilization of dunes, enhancement of ecosystem diversity, and achieving other objectives consistent with protection of existing resources; or under historic landscape restoration plan.

- Cutting of vegetation allowed for maintenance of trails and existing roads.

Water Resources

- Sensitive wetland resource areas and associated buffers will be managed to protect and enhance habitat and water quality.

Silviculture

- No conventional timber sales allowed. Areas in Environmental Protection Zone are excluded from allowable harvest calculations.

Forest Protection

o Spread of major forest pathogens will be controlled with procedures compatible with existing sensitive resources.

o Research stations for monitoring forest health may be established.

- Wildfires will be extinguished by Bureau of Fire Control personnel and Forest \& Park staff, coordinating with municipal fire departments.

- Fire breaks may be maintained in fire prone types of vegetation. 


\section{Transportation}

o No new roads will be constructed.

- Passage through zone allowed on existing stable roadbeds or trails.

Facilities

o No new construction except for small scale, low impact facilities such as interpretive exhibits, handicapped ramps, and boardwalks.

- No new construction in historic or cultural resource areas unless part of a formal protection or restoration plan.

CONSERVATION zONE: Areas in this zone are moderately sensitive, and may include managed woodlands, water resources, wildlife habitats, and agricultural resources. Opportunities for dispersed recreation are provided within this zone.

\section{Recreation}

o Opportunities for appropriate dispersed recreation will be provided.

Visual Resources

o Vistas will be opened in appropriate locations and open fields will be maintained.

- At least $50 \%$ shade will be maintained in a buffer strip along public access corridors.

Vegetation \& Wildlife Habitat

o A high priority will be given to enhancing ecosystem diversity.

o Wildlife nesting and den habitat areas will be encouraged.

- Activities adjacent to wetlands will be undertaken with adherence to regulations developed under the Wetlands Protection Act in order to avoid adverse impacts.

Water Resources

o Emphasis will be on maintaining and enhancing surface and ground water quality.

Agriculture

o Suitable agricultural uses will be encouraged where appropriate.

Silviculture

o Forest lands are divided into productivity classes (high yield and standard) with only high yield sites managed intensively.

- Management systems will be utilized to secure adequate natural regeneration and age class diversity.

- Timber Stand Improvement operations will be used to improve the quality and vigor of stands.

- Upon completion of operation, skid roads and landings will be stabilized. 
Forest Protection

o Spread of major forest pathogens will be controlled through environmentally sound programs.

- Research stations for monitoring forest health may be established.

- Wildfires will be extinguished by Bureau of Fire Control personnel and Forest \& Park staff, coordinating with municipal fire departments.

- Fire breaks will be maintained in fire prone types of vegetation.

- Research plots for prescribed burning and other techniques of fuel management may be established in this zone.

Transportation

- New road construction permitted in stable areas.

- Skid roads and truck roads will be carefully laid out by the forester considering grades, drainage and stream integrity.

Facilities

o Small scale facilities are permitted such as gravel parking areas, picnic areas, boardwalks, 2-4 stall comfort stations, and viewing platforms.

- Visitor centers, bathhouses, maintenance facilities, playfields, intensive camping areas, and major developments are not appropriate in this zone.

- Utility corridors are permitted.

- Adaptive reuse of historic structures is permitted in conjunction with a historic restoration plan.

- New construction in a historic or cultural resource area must be recommended as part of a formal protection or restoration plan, or historic landscape restoration plan.

INTENSIVE USE ZONE: Areas where resources can accommodate high levels of visitor use, and associated structures or maintenance facilities.

\section{Recreation}

- Legitimate recreational activities recognized by DEM, including intensive development-dependent recreation, are permitted in appropriate locations.

- Hunting will generally be excluded for safety reasons. MGL Ch.90B prohibits the discharge of firearms within 500 feet of occupied structures.

Visual Resources

- New structures and landscape treatments will be designed to blend in with natural or cultural surroundings, including use of trees and shrubs to screen utility buildings from view.

- Existing vistas will be maintained, and additional vistas may be cleared. 
Vegetation \& Wildlife Habitat

o Vegetation in natural resource areas will be managed by clearing out exotic species wherever possible, and maintaining trees and shrubs when their presence does not adversely impact public safety or access.

- Emphasis will be on maintaining vegetation with value to nongame wildlife species.

- Small scale wildlife habitat improvements may be conducted.

- Landscape plantings will consist of native materials in natural resource areas and historically compatible species in cultural resource areas.

Water Resources

o Surface water resources may be used for recreation within constraints of maintaining public safety and water quality.

- Surface water and associated wetland vegetation will be managed following guidelines established in the Wetlands Protection Act.

- Ground water resources may be utilized for day use and camping facilities.

Silviculture

o Acreage in this zone is excluded from allowable harvest calculations.

- Treatments will be conducted to improve public safety related to hazard trees and fire suppression, and improve access for recreation and education programs.

Forest Protection

o Spread.of major forest pathogens will be controlled through environmentally sound programs.

- Wildfires will be extinguished by Bureau of Fire Control personnel coordinating with municipal fire departments.

Transportation

- All main roads and bridges will be constructed or maintained to support a 75,000 pound load.

- Use of roads by logging trucks may be restricted during periods of high visitor use.

Facilities

o Construction directly related to appropriate forms of recreation will be allowed, and will conform to state health, building and environmental codes.

- Administration buildings, maintenance areas, storage facilities, parking lots, operational structures, visitors centers, bathhouses, playfields, and intensive day use and camping areas will be located in this zone.

- Utility corridors will be permitted.

- Historic restoration, rehabilitation or reconstruction for interpretation or adaptive reuse of historic structures is permitted in conjunction with an historic restoration plan. 
In addition to these zones that are based on the sensitivity of the natural and cultural resources, some resources are noted on federal, state, regional or local lists and registers, such as endangered species lists and historical registers. These significant resources are identified under the Land Stewardship Zoning systems and will be managed according to guidelines and recommendations from the associated or listing agency.

Important resource areas in DEM-managed forests \& parks are protected via a combination of environmental education and enforcement. Please refer to page $X$. in the Executive Summary for a more detailed explanation.

\section{Zoning for north-Quabbin area Forests \& Parks}

Most of the land within these forests and parks will be managed under the guidelines of the Conservation zone. The Conservation zone is shown in dark green on Figure 2 with no cross-hatching or other symbols.

Due to the scale of the map, the areas and zones outlined on Figure 2 represent only the approximate location of natural and cultural resources.

Two types of significance overlay areas are identified within the Conservation Zone and indicated on the accompanying map.

- Priority habitat areas recognized in the Natural Heritage Program Atlas in Warwick State Forest, Wendell State Forest,

- Orange State Forest, Templeton State Forest and Petersham State Forest will be managed under the Conservation Zone with additional guidelines obtained from the Natural Heritage staff. - Historical / cultural sites to be managed under the guidelines of the Conservation Zone with additional management guidelines established in coordination with the Massachusetts Historical Commission including determination of site integrity and significance.

DEM's Cultural Resources Inventory lists:

- Prehistoric village site in Federated state Forest.

- Native American burial ground in Montague State Forest.

- Native American camp sites in Northfield and Warwick State Forests.

- Family cemeteries in Northfield \& Warwick State Forests.

Large wetland areas, stream and river buffers will be managed under the guidelines of the Conservation Zone, with the additional protection afforded by the Wetlands Protection Act, Forest Cutting Practices regulations and all additional applicable legislation. 
The existing beach, picnic, camping and maintenance/headquarters and associated parking areas will be managed under the guidelines of the Intensive Use Zone.

Sites identified for potential expansion or development of intensive recreation facilities will be classified under the Intensive Use Zone - Reserved, including;

- area proposed for Erving SF campground expansion

- area proposed for Lake Dennison upper picnic area expansion

- area proposed for cabin/yurt construction in Wendell SF

- any potential swimming area upgrade or development

- new location comfort stations and other structural sites

A detailed analysis of natural and cultural resources at these devlopment sites must be conducted to ensure that sensitive resources will not be adversely affected. A methodology for determining whether or not a site is suitable for expansion or development of intensive recreation facilities is provided in the following section.

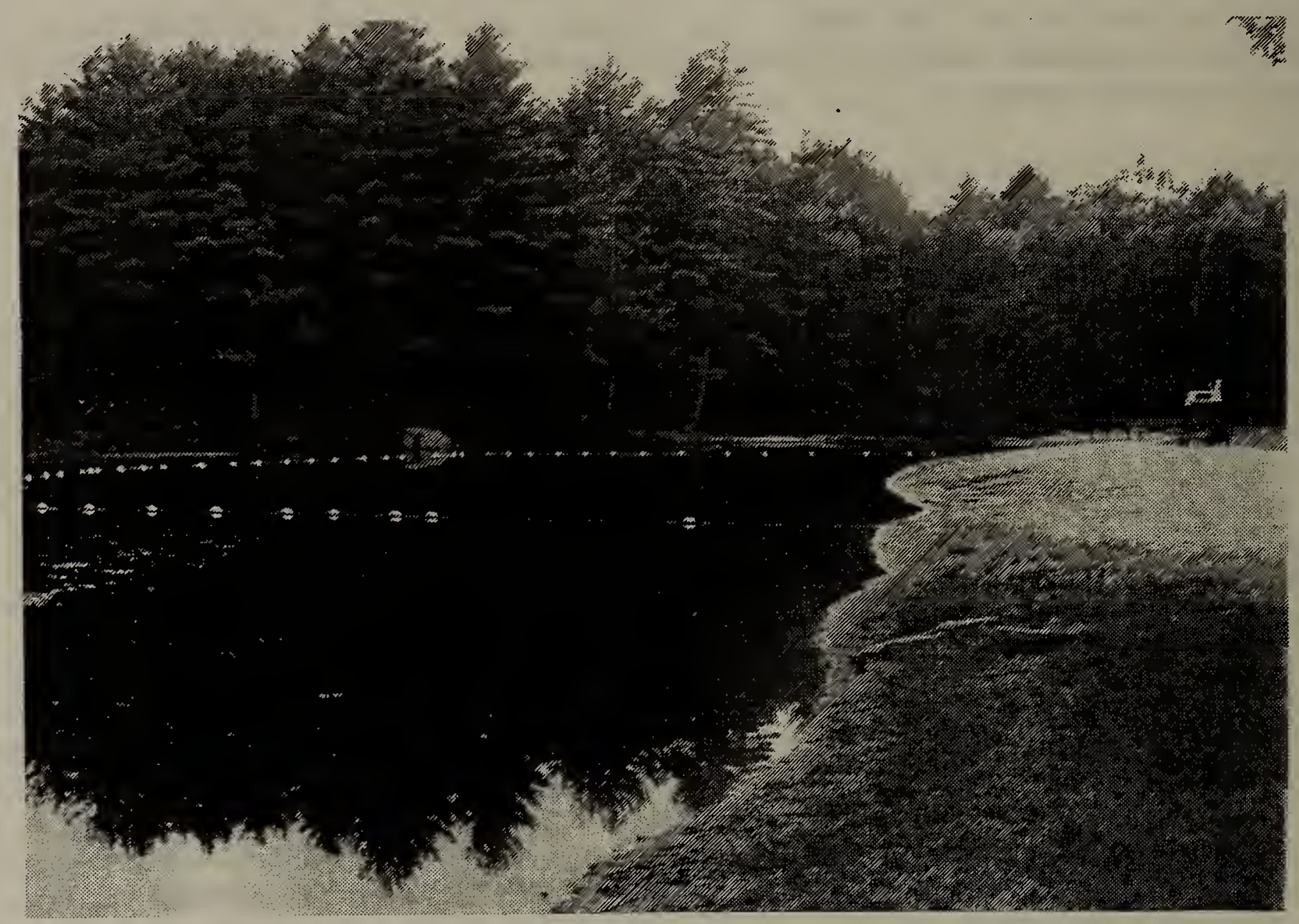

Ruggles Pond day use area in Wendell state Forest. 

Carrying capacity is the level of activity an area can support without causing unacceptable degradation of resources or unacceptable change to the recreation environment. Determining the carrying capacity of an area requires considering both descriptive and evaluative elements. Description examines and describes how the amount and distribution of visitors affects both the condition of the environment and the recreation experience. Evaluation depends on the ultimate goal for an area. This component incorporates value judgments about the acceptability of various impacts. This combination of description of impacts and evaluation of how acceptable those impacts are leads to a determination of how many visitors an area can support. Carrying capacity then becomes an important factor in developing management guidelines.

The descriptive component requires quantification of the relationship between uses and impacts. Impacts occur to both environmental and social systems. Adverse effects to resources can occur in a variety of ways and at a variety of different disturbance levels. The type of recreation activity, the season of use, short term weather conditions, the mix of species present, and physical parameters such as soil type and topography are all important aspects of the disturbance regime. Hikers, mountain bikers, horseback riders and ATV users can all cause varying amounts of soil compaction and erosion. The ecology and water quality of lakes and ponds can be altered through boating activities that inadvertently introduce pollutants or aggressive, exotic species. Rare or endangered plants are sometimes trampled if their habitat is located close to intensive recreation areas such as pondshores, camping areas, trails and playing fields. These are just a few examples of the myriad ways people can affect the ecology or recreation environment of an area while intending only to enjoy it.

Adverse effects on natural and cultural resources caused by recreation must be weighed against the many positive aspects of recreation. Outdoor activities are a vital part of maintaining physical and mental health. In addition, there are other social impacts, both positive and negative, to consider. Public access for recreation activities provides educational opportunities. It allows people to gain an appreciation of the great variety of natural and cultural resources in the Commonwealth, particularly when visits are supplemented with informational signs or interpretive programming. The appreciation gained will hopefully translate into improved stewardship for resources as more people realize the importance of all ecosystem components. Other social aspects of the visitor's recreation experience, such as the perception of crowding and management considerations related to the facilities and staff capabilities, must be considered in the determination of an area's carrying capacity. 
An objective analysis of the benefits and adverse effects of recreation is critical for an agency that must conserve resources while managing for public access. It is important to set reasonable threshhold levels. What level of change to the resources or recreation environment is acceptable? The end result should be an objective determination of how many users should be permitted in an area within the constraints of conserving sensitive natural and cultural resources.

\section{Laurel Lake Example of Determining Carrying Capacity}

The following case study, for boating on Laurel Lake, is provided as an example of how to use one method for determining carrying capacity. We have applied a method from Guidelines for Understanding \& Determining Optimum Recreation Carrying Capacity (see Appendix C).

This is an essential analysis for Laurel Lake because expansion of the parking area for the boat ramp is being considered as a long-term capital recommendation. However, there are concerns about conflicts between motor boats and other uses of the lake, and we should first determine a reasonable carrying capacity for these uses. In a similar way, carrying capacity analyses must be conducted prior to implementation of proposed capital improvements such as Erving campground expansion, Lake Dennison picnic area expansion, or development of new swimming area facilities.

- Laurel Lake has a surface area of approximately 50 acres.

- The functional power boating area is less, because a buffer area along the margin of the pond and for the swimming area must be considered. The buffer area will be estimated as 100 feet times the perimeter of the lake, which is approx. 8500 feet.

- Using these figures, the buffer area is approx. 20 acres, leaving 30 acres of the pond available for power boats. Approximately 45 acres of the pond is available for non-motorized boats when the swimming area and shallow pond margins are subtracted from the 50 acre total.

The information on the following two pages is based on excerpts from Guidelines for Understanding \& Determining Optimum Recreation Carrying Capacity: Additional information from this source is provided in Appendix C.

Optimum carrying capacities vary from place to place because of variable physical site conditions and participant situations. The carrying capacities presented here are descriptions of impacts at different levels of use and are shown as a range of possible optimum capacities from which a recreation administrator or planner can choose. The suggested range indicates suggested low and high optimum capacity limits. A "base" capacity figure 
is also given within the range; this base figure represents an optimum capacity level from the results of the state standards Inventory, the Participant Survey, and the Administrator/Planner Survey. This base level assumes that the recreation activity is being conducted under the most normal and typical site conditions and participant situations for that activity.

The suggested ranges of optimum carrying capacity are based largely on the results of the Participant Survey and the Park Administrator/Planner Survey. The professional survey team that conducted the interviews reviewed and evaluated the low, high and average optimum capacity responses resulting from the surveys. The Survey Team then reached a consensus concerning an appropriate optimum capacity range for each outdoor recreation activity.

Factors that affect carrying capacity for boats:

1) Location of recreation activity - Visitors in an urban area will generally expect, tolerate, and accept more crowded conditions than visitors who travel to remote locations.

2) Quality of site amenities - The number and quality of site amenities affects a person's willingness to tolerate and accept higher levels of capacity; therefore, recreation sites with amenities such as scenic natural features, views or vistas can generally. be operated at a higher capacity.

3) Multiple use of the water - The number of boats per acre should be lower if other activities such as swimming are also occurring.

4) Shoreline configuration - Water areas with very irregular shorelines should, on the basis of safety, accommodate fewer boats per acre than areas with regular, even shorelines.

5) Circulation patterns, horse power or speed limits - Water bodies with defined ski lanes can safely accommodate more boats per acre than unmarked water bodies which allow a random pattern of tow paths.

6) Degree of policing or supervision - Policed or supervised areas can support more boats per acre than unsupervised areas. Boating regulations can also allow for a greater use level.

7) Types of aquatic life - Certain types of aquatic and pondshore life, under certain circumstances, are sensitive to large volumes of boat traffic.

8) Depth of water - Water areas that are shallow should accommodate fewer boats per acre. 
9) Rate of water turnover - The faster water is circulated through the system, the more boats the water area can accommodate related to eventual dissipation of oil and gas contamination.

Factors allowing a greater number of boats on Laurel Lake:

2) Laurel Lake and the surrounding landscape can be considered a very scenic area.

4) The shoreline has a fairly even and regular configuration.

6) The area is supervised, there are DEM CMRs related to speed limit and time of day when water skiing is permitted, and there is also a 10 horse power limit on the portion of the lake that lies within the Town of Warwick. However, greater law enforcment support is needed.

8) The lake is fairly deep with a maximum depth of approx. $30 \mathrm{ft}$.

Factors allowing a lesser number of boats on Laurel Lake:

1) The lake is located in a rural, fairly remote area.

3) The lake is used for swimming, fishing, motorized and nonmotorized boating.

5) There are no established boating circulation patterns at this time.

9) The Living Lakes report indicates that the hydraulic retention time is 1.5 years, a fairly slow turnover.

Factor that will not be used as a plus or minus:

7) Rare or endangered species are not a factor, but DFW stocks the lake with trout that require clean, cold, well oxygenated conditions.

Positive and negative carrying capacity factors for boating on Laurel Lake are fairly even. This would suggest an optimum capacity at the base level shown on the following graphs.

SKIING, WATER

Suggested Optimum Capacity Range

ACRES OF WATER/BOAT LOW $\quad 20 \quad 12 \frac{\text { High }}{7}$

BOATING, UNLTMITED POWER

Suggested Optimum Capacity Range

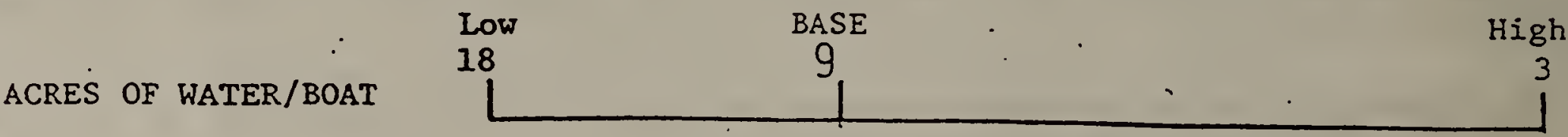


BOATING, NON-POWER FLAT WATER

Suggested Optimum Capacity Range

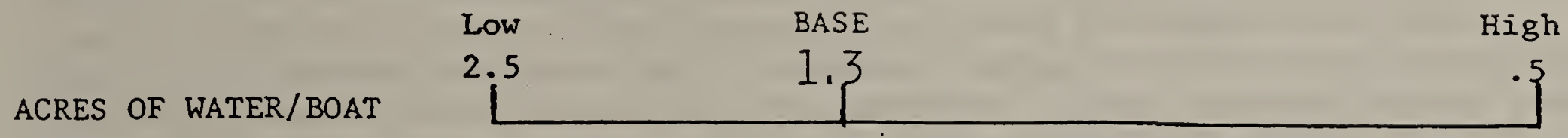

Given the 30 acres available for power boats, and 45 acres available for non-motorized or electric motor boats, this would set a base level of only 2 or 3 water skiers at one time, or three power boats without skiers, or about 30 non-motorized or low-power electric motor (fishing) boats. On a crowded weekend during the summer, the current use of the lake easily exceeds this estimated capacity.

Carrying Capacity and Management

The purpose of this paper analysis is to provide a starting point to define a safe and enjoyable level for use of boats on Laurel Lake. This initial analysis must be improved with refinements from the on-site experience of park staff, public input, and adjustments after implementation (if we are able to increase enforcement capabilities).

The preceding carrying capacity analysis is visitor oriented rather than resource oriented due to the issue of water

recreation safety at Laurel Lake. However, this general type of analysis is flexible enough for determination of appropriate visitor use levels that will allow for protection of sensitive natural and cultural resources. For example, It would be beneficial to conduct an analysis related to the potential construction and use of cabins in Wendell state Forest near Ruggles Pond. A Special Concern species, the Four-toed Salamander has been found to inhabit a wetland area located to the northeast of Ruggles Pond. Construction and use of cabins would have to meet the criteria of causing no degradation of the swamp habitat. Thresholds for siting potential cabins could be evaluated via site inspections in coordination with the DFW Natural Heritage \& Endangered Species Program to determine; -width of upland buffer where no disturbance is acceptable, -width of additional buffer where minimal visitor impacts are acceptable,

- suitable site for potential cabins,

-management methods to direct visitor use.

DEM is initiating a research program to address a variety of topics that are directly applicable to DEM management concerns. Topics may include ecological restoration, insect/pest management, and impacts to resources from various types of recreation. In addition, several parks have established a monitoring program to determine impacts of trail use. Research of this nature, and analyses similar to the one described above will increase DEM's knowledge of carrying capacity, enhancing stewardship of the forests \& park.s. 
DEM is steward of over one-quarter million acres of conservation land in Massachusetts. DEM's objective is to maintain a diversity of habitats within the forest \& park system, including relatively undisturbed inner forest areas, supporting an important component of plant and animal diversity in Massachusetts. Other public agencies, nonprofits and private landowners are also responsible for stewardship of a considerable diversity of habitats across the state. Long-term conservation of biodiversity will also rely on management decisions and actions of these landowners.

The north-Quabbin region is unusual relative to most of Massachusetts because it still has considerable continuity of forested land, notwithstanding the substantial road network and patchy residential/commercial/industrial development. Maintaining continuity of inner forest habitat is important related to overall diversity of plants and animals in an ecosystem because habitat fragmentation caused by development adversely affects some forest species. The effects include;

- a reduction in species that thrive in large tracts of undisturbed forest, such as the wood Thrush and other songbirds, the River Otter and Fisher..

- an increase in opportunistic omnivores such as Blue Jays, Crows, Raccoons, and Opossums, and an increase in Cowbird parasitism of songbird nests.

- a reduction in large predators such as owls and hawks, which would normally tend to keep the opportunistic omnivores in check.

- disruption of migratory routes that tend to isolate populations.

- an increase in the likelihood of aggressive non-native plant species becoming established.

Due to these factors, the gradual loss of inner forest habitat in Massachusetts is adversely affecting biological diversity.

The natural diversity of an ecosystem provides a region with stability to recover from onslaughts of pests, diseases, fires and storms. The species of plants and animals in this region also have recreational and esthetic value for the many people who enjoy bird watching, identifying plants or other aspects of nature appreciation. Managing an area to maintain species diversity is sensible because many species have potential to provide biochemicals for medicine or have other economic values.

Maintenance of biodiversity at the landscape level requires conservation of large areas that include the most diverse ecosystems. The provision of greenway corridor connections and buffers for these areas allows for species migration and protection of inner forest habitat. The pattern of forest ownership and use is the key factor in any land protection strategy that attempts to maintain continuity and biodiversity at the landscape or ecosystem level. In Massachusetts, the 
objectives of private landowners are the most important consideration in developing this type of conservation plan. Considering the number and size of privately-owned forest parcels, a workable strategy to manage or conserve open space is not easy to achieve for a large region or river basin. area. However, planning can be positively influenced by public education, landowner incentives, and government support of local initiatives.

The Forest Legacy Program is an example of federal, state and local coordination for the conservation of open space and forest resources in this region. The Program was established as part of the federal 1990 Farm Bill. The purpose is to "identify and protect environmentally important privately-owned forest lands threatened with conversion to non-forest uses, and to authorize USDA Forest Service purchase of conservation easements of forest land as a way of slowing such conversions." By retaining these lands in traditional forest uses, such as timber harvesting and dispersed recreation, these lands can yield positive future benefits in economic stability and employment, and support tourism which depends on the aesthetics of the Massachusetts landscape.

The Program required Massachusetts to prepare an assessment of need for the state, and to delineate boundaries of forest areas that meet eligibility requirements for designation as Forest Legacy Areas. Mount Grace Land Conservation Trust (MGLCT) has taken the vital role as sponsor for the Forest Legacy Program in the north-Quabbin region. MGLCT has identified two important contiguous forest areas that meet the Forest Legacy criteria (see "accompanying maps). Both areas are part of a 50-mile corridor of protected land spanning 10 towns and 80,000 acres. A 490-acre portion of the region has been protected with a conservation restriction funded by the USDA Forest Service, and additional land protection efforts are in progress.

The Forest Stewardship Program, which is administered by DEM, is a good example of an incentive program for owners of large forested parcels who are interested in practicing long-tèrm guardianship of their woodlands. Under the guidelines of this Program, landowners develop and implement stewardship plans to improve wildlife habitat and forest esthetics, to protect soil and water resources and to ensure a renewable supply of high quality wood products.

A "stewardship neighborhood" has been initiated in North Orange. Eight abutting landowners with land holdings totaling more than 650 acres, were organized together by a consulting forester, and are developing a cooperative approach for management of their private forested parcels. The consulting forester requested funding from the Forest stewardship Program to review and coordinate the management plans. This is a good example of the potential for an ecosystem based approach to forest management across private ownerships. The success could be publicized and promoted by regional nonprofits such as MGLCT and the Millers River Watershed Council. 


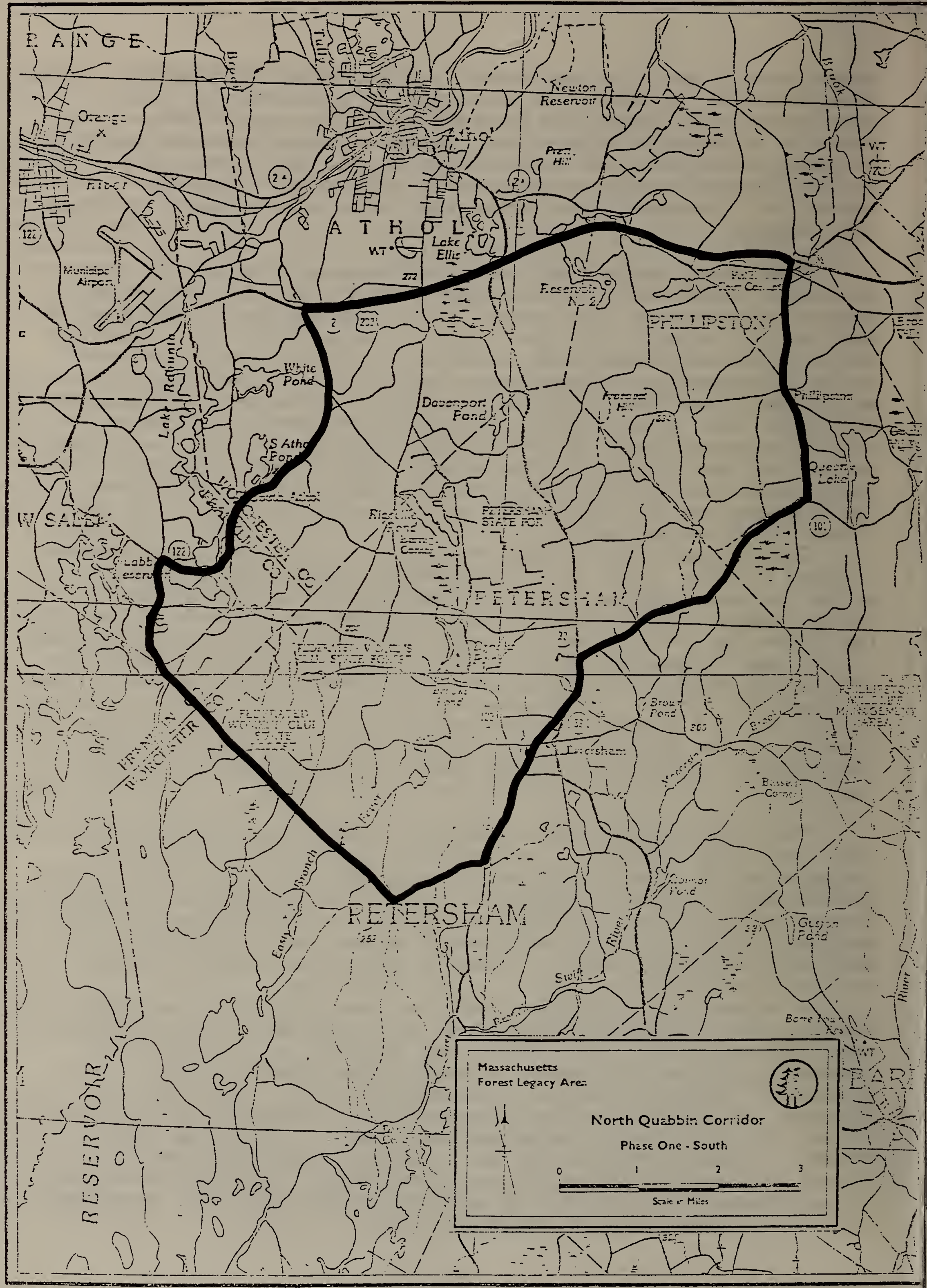


Assessment of wildlife habitat requirements, native plant and animal population viability, and other aspects of ecosystem health is best conducted at the local to landscape scale (hundreds to hundreds of thousands of acres). Gap analysis is one method for this type of assessment, using remote sensing technology combined with field checks for verification. The principle of gap analysis is to identify where there are gaps in protection of cover types or ecosystems, and hot spots of species diversity. A description of several modified gap analyses conducted or ongoing in Massachusetts is provided in Appendix $D$.

Using the EOEA's ARC-INFO Geographic Information System, a modified gap analysis was conducted for a small portion of the north-Quabbin region. The intention is to highlight important ecological areas and inner forest habitat that are unprotected, and also to highlight viable greenway corridors that could potentially connect existing open space. The initial results indicate that the analysis has good potential as an acquisition planning tool for DEM. Also, the perspective obtained from this type of analysis could be used for prioritization of conservation strategies, by the environmental organizations that work with private landowners in this region. These groups include: the Mount Grace Land Conservation Trust, which has protected thousands of acres of land with cooperative projects, including several with DEM; the Millers River Watershed Council; the AtholOrange Greenway Committee; Trustees of Reservations;

Massachusetts Audubon Society; Army Corps of Engineers; EOEA agencies; the Harvard. Forest; and considering the importance of the Millers River basin as a subbasin of the Connecticut River, the working groups associated with the Conte Refuge and the

- Connecticut River Valley Open Space Planning.

\section{Recommendations}

- Expand coverage of gap analysis and supplement with detailed cover type data from the USFWS/UMass analysis, and combine with detailed land ownership information where feasible. Field checking of areas identified by the analysis is an important aspect of this evaluation.

- Determine if there is interest in combining efforts of the diversified groups listed above to form a regional Greenway Council., in order to facilitate the cooperative identification and acquisition of priority inner forest habitat and corridor connector sites.

- The analysis also shows important habitat areas that are already managed for conservation purposes by public and nonprofit agencies. DEM should take maintenance of interior forest habitat (or biodiversity) into account in making management decisions within the forests \& parks of this region. DEM will objectively review Wildlands Program (Backcountry Areas \& Representative Natural Areas) nominations for the forests \& parks in this region. Nominations can come from within the agency, or from conservation groups and individuals.

- Actively participate in the Commonwealth's Watershed

Initiative, as contributing member of Millers River basin team, to promote and implement planning strategies for long-term conservation of biodiversity in the river basin. 


\section{LAKES \& PONDS}

\section{$\underline{\text { BACKGROUND }}$}

An important component of the natural resources found in the landscape north of the Quabbin Reservoir are the lakes and ponds. Lakes and ponds have significant values for the people who treasure them for their scenic and recreational uses. The open bodies of water provide an important role in the habitat for many species of plants and animals.

Seven lakes and ponds located within the state forests and parks (Figure 3) are covered in depth in this study. Data gathered from previous studies, and samples taken under DEM's Lakes \& Ponds Program in the late-summer 1994, have been assessed to develop recommendations for stewardship of these lakes and ponds. The physical features of each lake and pond are described below (Table 1) and lake/pond bottom sediment is described on the following page (Table 2). A variety of water quality factors and key indicators are reviewed to determine the health of each waterbody and its suitability for various uses.

\section{EXISTING CONDITIONS}

Table 1. Lake Morphometry (approximate values).

\begin{tabular}{|lccccc|}
\hline Lake / Pond & $\begin{array}{c}\text { Drainage } \\
\text { Area } \\
\text { (Acres) }\end{array}$ & $\begin{array}{c}\text { Average } \\
\text { Depth } \\
\text { (Feet) }\end{array}$ & $\begin{array}{c}\text { Maximum } \\
\text { Depth } \\
\text { (Feet) }\end{array}$ & $\begin{array}{c}\text { Lake } \\
\text { Area } \\
\text { (Acres) }\end{array}$ & (Acre-feet) \\
Beaman Pond & 475 & 4 & 10 & 2.25 & 9 \\
Lake Dennison & 2061 & 8 & 15 & 85 & 680 \\
Dunn Pond & 550 & 11 & 24 & 20 & 220 \\
Laurel Lake & 486 & 10 & 30 & 51 & 510 \\
Sheomet Lake & 3400 & 6 & 13 & 33 & 198 \\
Ruggles Pond & 787 & 3.5 & 6 & 19 & 66 \\
Wickett Pond & 275 & 4 & 10 & 25 & 100 \\
\hline \hline
\end{tabular}


Table 2. Sediment Description

Lake/Pond

Lake/Pond Bottom Description

Beaman Pond

Mineral soil predominates, with a shallow layer of algal lake mud in some locations, especially near the inlets and towards the middle of the pond.

Lake Dennison

Dunn Pond

Laurel Lake

The shoreline and coves contain sand and gravel overlain by up to 5 feet of algal lake mud with sand and gravel on the shore.

Post-glacial mineral deposits were exposed by dredging associated with the mid-1980's restoration project. Mineral bottom is gradually being covered by a shallow layer of algal lake mud.

Laurel Lake

Sheomet Lake

The bottom is mostly gravel, except the shallow coves at the western and eastern ends that contain as much as 3.5 feet of algal lake mud.

The bottom is characterized by muck and gravel with rock outcroppings and several islands.

Ruggles Pond There is a uniform layer of mud 3.5 to 4 feet deep. The stumps and forest soils were not removed prior to impoundment of this man-made pond.

Wickett Pond Glacial gravel is overlain by up to 20 feet of algal lake mud.

\section{ANALYSIS}

Water quality is an important factor in the ecology and recreational use of a lake or pond. Pollution can have direct impacts on water quality and recreation, and it can lead to other water quality problems, such as weed infestation that reduce recreational values. Leaking septic systems can introduce viruses and unhealthful bacteria directly into a water body. Runoff may bring excess nutrients to the lake system, causing algal blooms, fish kills, unpleasant taste and odor, and reducing water clarity. All of these factors can lessen the potential for swimming, fishing, and boating. The overall integrity of the lake ecosystem relative to types and numbers of aquatic species may also be impacted. 


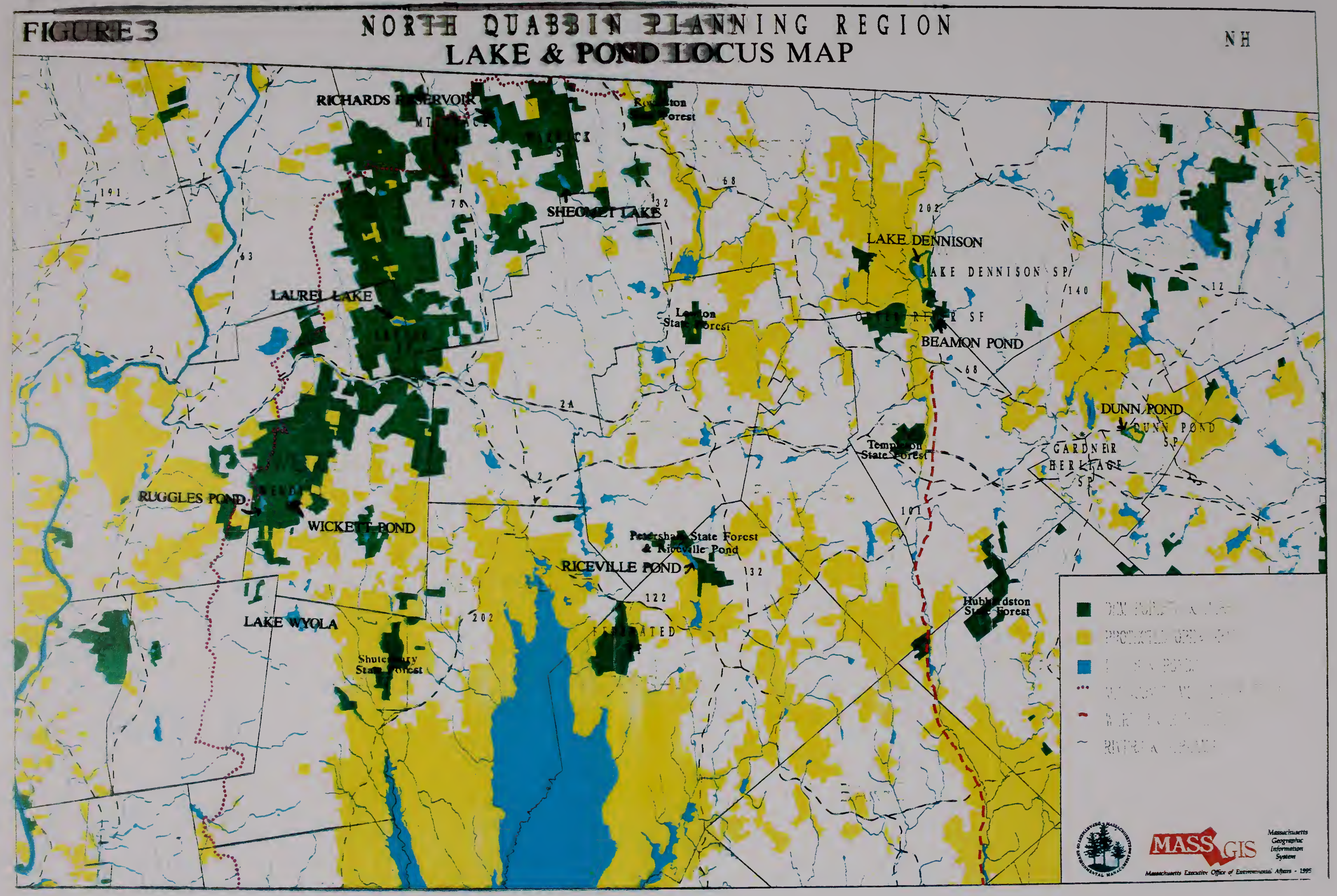



Several indicators are used to measure the water quality and health of a lake or pond. Important water quality measurements include:

- Clarity or transparency, which is affected by suspended solids including microorganisms from within the lake ecosystem, and by organic acids and other sources of sediment from the watershed,

- Temperature level throughout the water column, which is affected by the depth of the lake, and by factors such as wind and spring and fall overturn of the water column,

- Dissolved oxygen level throughout the water column is strongly affected by temperature conditions,

- Acidity coming into the lake system from a forested watershed or from acid precipitation, and the lake's natural buffering capacity that might allow for fairly stable pH conditions in spite of acidic input,

- Conductivity measures the abundance of ions such as chloride that might come into the lake system after originating with the application of salt on nearby roadways,

- Coliform bacteria levels, used to estimate potential for fecal contamination that could be accompanied by other pathogens,

- Nutrient levels, such as phosphorus and nitrogen, possibly originating from land use activities or septic systems, and which strongly affect aquatic plant growth. A lake or pond is classified as to its trophic status, i.e. oligotrophic, mesotrophic, or eutrophic, based on the amount of phytoplankton and macrophyte growth, which is highly dependent on availability of nutrients, especially phosphorus. An oligotrophic lake generally has a low phosphorus level with minimal plant growth and very high clarity, usually making it an excellent resource for water-based recreation. A eutrophic lake is at the other end of the spectrum with high nutrient levels, which is usually conducive to an abundance of suspended and rooted plants.

- Aquatic animals and plants - types and abundance (including phytoplakton and floating or emergent macrophytes). 
Table 3 describes the distribution of aquatic plants found in the study area lakes and ponds. The following macrophyte species, which may have an adverse affect on recreation activities, occur in Massachusetts lakes and ponds:
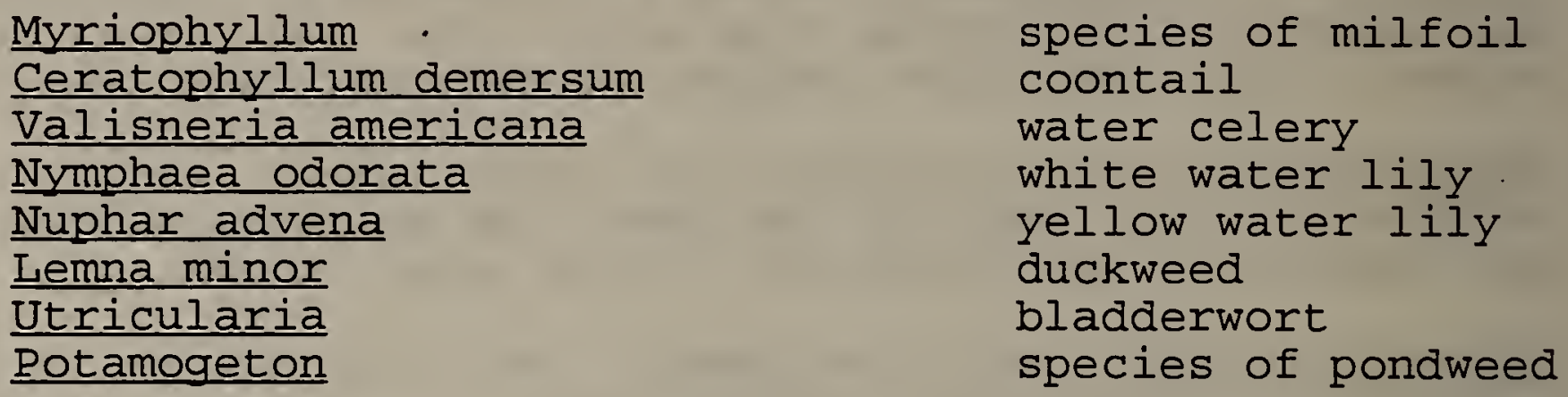

Table 3 .

\begin{tabular}{|c|c|c|c|c|c|}
\hline \multirow[b]{2}{*}{ Lake / Pond } & \multicolumn{5}{|c|}{$\begin{array}{l}\text { Distribution of Aquatic Vegetation } \\
\text { Percent Cover for Each Sampling Station }\end{array}$} \\
\hline & $\begin{array}{r}\text { Sparse } \\
0-25 \%\end{array}$ & $\begin{array}{l}\text { Moderate } \\
25 .-50 \%\end{array}$ & $\begin{array}{l}\text { Dense } \\
50-75 \%\end{array}$ & $\begin{array}{l}\text { Very Dense } \\
75-100 \%\end{array}$ & $\begin{array}{l}\text { Total } \\
\text { Stations }\end{array}$ \\
\hline Beaman Pond & 6 & 2 & 0 & 0 & 8 \\
\hline Sheomet Lake & 12 & 3 & 1 & 1 & 17 \\
\hline \multirow[t]{2}{*}{ Wickett Pond } & 1 & 2 & 1 & 16 & 20 \\
\hline & \multicolumn{5}{|c|}{ Description of Aquatic Vegetation } \\
\hline Lake Dennison & \multicolumn{5}{|c|}{$\begin{array}{l}\text { Moderate problem with shoreline vegetation, } \\
\text { but growth was generally sparse }\end{array}$} \\
\hline Ruggles Pond & \multicolumn{5}{|c|}{ Severe problem overall } \\
\hline
\end{tabular}


Beaman Pond is located in the Otter River state Forest in the Town of Winchendon. It is part of one of the oldest public campsites in Massachusetts. The Pond is a popular recreation site for swimming by day-users and campers from the adjacent campsites. There are two beaches to accommodate both day-users and the one hundred campsites at the Pond. There are many picnic tables and a pavilion along the shore.

Beaman has two tributaries, one from Mill Glen Pond, and the other from a small pond in a forested upland. A CCC dam, constructed in the 1930's, impounds the Pond. Water flows through two dam outlets eventually leading to the otter River and the Millers River.

The clarity of Beaman Pond is marginal related to regulations for public swimming. The transparency of the water, measured by the secchi depth in late-summer 1994 was 1.1 meters (less than 4 feet) with a tea color. The color and lack of clarity is probably due to the abundant population of phytoplankton in the pond ecosystem, and humic acids flowing in from wetlands in the watershed.

There were very few macrophytes when the Pond was sampled by DEM staff in late-summer 1994. However, a small amount of the exotic nuisance species Elodea was found during the 1994 sampling. Despite the lack of aquatic plants, the Chlorophyll-a level indicates that the pond is borderline between mesotrophic and eutrophic.

A comparison of phosphorus and nitrogen levels at the stream inlets versus the dam outflow point highlights a separate origin for these two elemental nutrients. The streams seem to be bringing in phosphorus from upstream sources in the watershed, while there may be a source of nitrogen in the area immediately surrounding the pond.

There is a small decrease in dissolved oxygen with depth, but the pond is too shallow to be subject to seasonal stratification. The oxygen levels are suitable for the pan fish population, that is annually supplemented by a park staff stocking program, intended for the benefit of young fishing enthusiasts from the campground. The pond was mildly acidic measuring in the low 6 range for $\mathrm{pH}$. Measurements at the inlets were $\mathrm{pH}$ 6.5. Although this level of acidity is very reasonable, most of the pond's acid neutralizing capacity has been expended. The natural buffering capacity is determined by the amount of calcium carbonate and other sources of alkalinity present per volume of water.

A moderately high specific conductance in the pond may have come from road salt and/or wastewater in the inlet streams that pass under Route 202. 
Recommendations

- The cause(s) of Beaman's marginal water clarity must be assessed and remediated so that the pond can be maintained as a viable swimming resource. The following two items could be related to the pond's water quality.

- Additional study is needed to determine the origin of nitrogen, phosphorus, and salts that are reaching the pond. This could potentially be accomplished through shoreline surveys organized as educational programs by park interpreters.

- Work with MHD District Office to consider reduced road salt use.

- The impacts on Beaman Pond from the annual drawdown of Mill Glen Lake should also be determined.

- pH and acid neutralizing capacity should be measured annually due to the marginal remaining buffering capacity of this pond. Remedial treatment should be considered if the pH drops below 5 .

- Replace vault toilets with Clivus composters.

- Regular drawdowns of Beaman Pond have been effective for control of aquatic vegetation and dam safety inspections and should continue pursuant to the Order of Conditions issued by the Winchendon Conservation Commission (DEP File \# 345-170). DEM must apply for an Order of Conditions extension every three years. Contact Winchendon Conservation Comm in late-fall 1997.

- Dam rehabilitation work as prioritized by the Dam Safety Program in coordination with Division of Forests \& Parks.

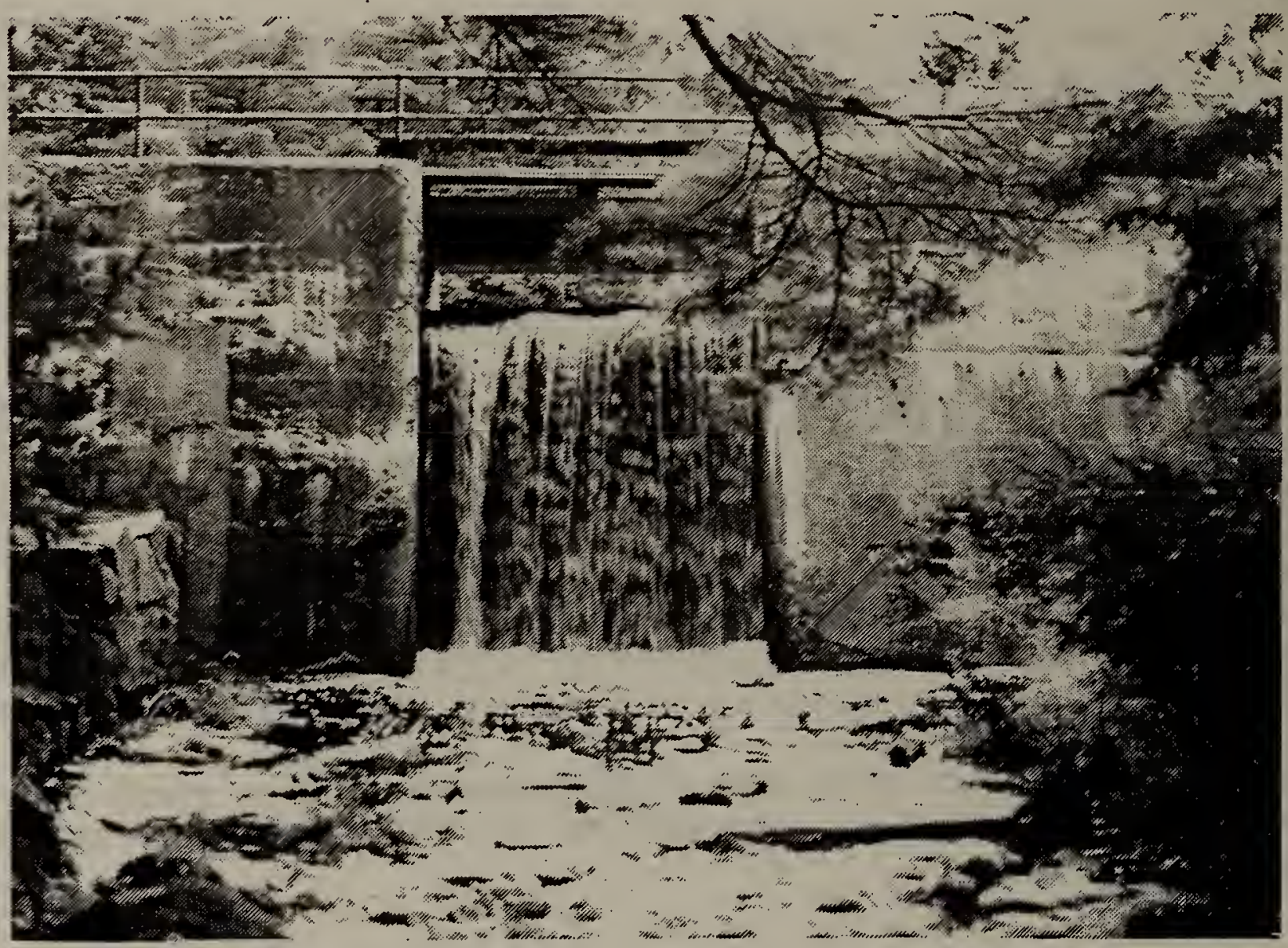

Outflow from the Beaman Pond dam. 
Lake Dennison is located within a flood control facility operated by the Army Corp of Engineers (ACOE). The lake has a surface area of 83 acres and a maximum depth of 15 feet. The watershed drains over 2,000 acres.

The primary objective of Lake Dennison is flood control and the water level is controlled by the ACOE. DEM manages the lake and surrounding recreation area and forested land under a 50-year lease with the ACOE. Recreation is supervised by Otter River State Forest. The two agencies therefore provide multiple functions with this reservoir, with flood control as the primary function.

The North and East Dennsion Camping Areas provide 150 campsites at the Lake. In addition, there is a large parking area, boat ramp, beach, pavilion, and dam. In addition to summer recreation such as swimming and non-motorized boating, there are many winter recreational opportunities including snowmobiling and $\mathrm{x}$-country skiing. Fishing is a popular activity at Lake Dennison year-round. DFW stocks the lake with trout on an annual basis.

Lake Dennison has a moderate problem with planktonic algae and a moderate problem with shoreline weeds and water color. The lake did have some shoreline vegetation, including pickerelweed. The lake experienced some thermal stratification with markedly lower dissolved oxygen at its greatest depth. One of the two inlets had a much higher amount of total solids and a much higher specific conductance. This northern inlet also had a greater amount of chloride, and a relatively lower level of nitrogen. Evidence suggested that phosphorus did not come from the sediments. The low acid neutralizing capacity of the Lake made it susceptible to acidification. Water clarity was marginal but acceptable. Phosphorus levels were also acceptable. Total coliform was recorded at 100 and 200, within the EPA limit of 1,000 per $100 \mathrm{ml}$. There is erosion in isolated locations within the campground along the northern and eastern shores.

Recommendations

- Conduct initial check of septic systems and rehabilitate as necessary. Pump annually in Fall after recreation season.

- The level of boating activity warrants special precautions to prevent the introduction of exotic macrophytes such as milfoil.

- Erosion control measures should be implemented on steep slopes in the campgrounds to prevent excess siltation.

- Shoreline survey of inlets, especially northern inlet, including check of highway garage location as possible source of excess chloride.

- Coordination with DFW related to annual pH testing associated with stocking program, and development of recommendations for remedial treatment with DFW if necessary, to maintain the lake as a fishing resource. 
Dunn Pond is part of the Gardner Heritage state Park located about a mile from the center of Gardner. This roughly 20 acre pond is a glacial kettle hole with a dam increasing the pond's depth. Dunn Pond was subject to a natural succession that was exacerbated by human impacts. Following an extensive cooperative effort to restore Dunn Pond, it is once again a high quality waterbody and a center of recreation. Visitor usage has increased over 200 percent, clearly demonstrating the success of these efforts.

Dunn Pond was severely affected by pollution from its watershed, which caused eutrophication. The pond was filling with sediment and was characterized by dense growth of aquatic vegetations. When the City and DEM cooperated to bring the pond under DEM management as part of Gardner Heritage state Park, plans were made for the pond's cleanup and revitalization, which included complete drawdown and dredging of sediment. The work was done as a cooperative restoration effort by local, state, and federal agencies. The restoration was guided by the Department of Environmental Protection's Division of Water Pollution Control. Funding came from the U.S. EPA, the Massachusetts Chapter 628 Clean Lakes and Great Ponds Program, and the Chapter 798 Urban Heritage State Park. Work began in January, 1984, and was completed in March, 1985. The project included excavation of the adjacent stump Pond, the construction of a filter dike at Stump Pond, and the diversion of stormwater through stump Pond. Stump Pond is now used as a detention basin, greatly reducing the amount of sediment, runoff, and road salt that reaches Dunn Pond. A 1996 rehabilitation project addressed several ongoing maintenance issues that effect water quality in Dunn Pond. The work included restructuring, cleaning and replenishing filter sand for the stump Pond filter dike, redressing of the dam spillway, and the removal of old blacktop and stabilization of eroding banks where the lakeshore closely parallels Pearl street. The expenditures have paid off with the successful restoration and protection of Dunn Pond. It has become a much cleaner, and popular center for recreation and enjoyment near the urban center of Gardner. Rehabilitation and improvements have been conducted to allow for maximum accessibility, following ADA guidelines. Dunn Pond state Park is considered the model DEM property related to accessibility standards. Swimming, nonmotorized boating, and ice skating are some of the water recreation opportunities at Dunn Pond today. The shore has a picnic area, a large visitor center, beach, and lights for the skating area. The pond is stocked by DFW and is a very popular fishing resource.

Measurements made after Dunn Pond was refilled indicate areas of potential concern related to water quality. The seasonal temperature stratification causes low oxygen conditions in the deeper water during the summer, which could potentially have adverse effects on fish populations. The water is also quite acidic, although the $\mathrm{pH}$ has recovered somewhat from the low level measured at the time the pond was refilled. Finally, conductivity measurements indicate that road salts and other ions 
are entering the pond in fairly large quantities. The conductivity of Dunn Pond is twice that of Stump Pond's tributaries, demonstrating that the source of pollution is probably runoff from roads and other watershed sources immediately surrounding Dunn Pond.

Macrophytes are generally no longer a problem at Dunn Pond, although aquatic plants do exist in a fairly dense coverage near the inflow from stump Pond, partially along the island, and in a cove near the dam. Macrophytes growth also occurs at the end of the Pond near the dam, and scattered along the shoreline.

\section{Recommendations}

- Considering the successful cooperative effort and expenditure of funds, the water quality of the Dunn and Stump Ponds, and the integrity of the filter dike need to be monitored and maintained.

- Immediate steps have been taken to reduce the erosion at the northeast and northwest corners of Dunn Pond, such as hay bales or silt screen barriers. This should be followed by more permanent measures.

- DEM will work cooperatively with Gardner for the transfer of deed to stump Pond from the City to the Commonwealth so that DEM can actively maintain this key element for the protection of Dunn Pond.

- Catch basins on Pearl street and Betty Spring Road need to be regularly cleaned.

- The riser pipe spillway elevation needs to be maintained 1106.0 feet, to prevent unfiltered water and pollutants from entering Dunn Pond.

- Accumulated sand and silt should be removed from storm drain pipe outlets and surrounding pond bottom.

- Clogged 30 inch drain pipes should be flushed, especially at the southeast corner.

- In order to limit the amount of solids from accumulating in the filter system, assistanc might be sought for Gardner's limited street sweeping and cleaning catch basins.

- Inspect the filter dike on a regular basis. Title of Stump Pond parcel transferred from City to DEM.

- All brush and trees should be cleared from the earthen dam located at the south end of the pond.

- Erosion control rehab for existing pond trails.

- Coordinate with DFW related to annual pH testing associated with stocking program, and development of recommendations for remedial treatment with DFW if necessary, to maintain the pond as a fishing resource.

- Implement LWCF Universal Access construction phase with Best Management Practices to maintain water quality parameters.

- Description of the dam and additional recommendations are in Appendix I. 
Laurel Lake straddles the town boundary between Erving and Warwick in Erving state Forest. It covers 51 acres, but is narrow with a maximum width of approximately 700 feet. It has an average depth of 15 feet and a maximum depth of 30 feet. The drainage area is 486 acres. There are seasonal cottages on the opposite shore from the beach and swimming area.

The swimming beach includes a new accessibility ramp that leads into the water. A parking area and boat ramp provide access for motorized and nonmotorized boats. 304 CMR 16.10 permits water skiing only between noon and $6 \mathrm{p} . \mathrm{m}$., speed is limited to $10 \mathrm{~m} . \mathrm{p} . \mathrm{h}$. during all other times. Other facilities at the lake include a concession building, new comfort station, campground, and picnic area. Swimming is especially popular. scenic vista can be reached via a short loop trail. DFW stocks the lake with trout on an annual basis and fishing is a popular activity throughout the year.

Laurel Lake underwent water quality monitoring by Living Lakes, Inc. beginning in 1987. Laurel Lake was found to be slightly acidic, with a marginal buffering capacity. Following recommendations from the Living Lakes Program the lake was limed in October, 1987 and again in May, 1991 because tests conducted after the initial treatment showed that the lake was reacidifying. Subsequent treatment and monitoring suggested that the level of acidity would be sufficient to maintain water quality through 1994. Aluminum may become more concentrated in acidic lakes and can be toxic to fish populations in low concentrations. Although dissolved aluminum concentrations in Laurel Lake were found to be above 60 micrograms per liter, the fish populations did not appear to be stressed. The lack of stress could not be fully explained, but it may be explained by the high levels of calcium.

Other water quality variables monitored by the Living Lakes Program included transparency, temperature, and dissolved oxygen. The transparency of the lake water was good, ranging from 4 to 5.5 meters. Laurel Lake became stratified by water temperature gradient during the summer and dissolved oxygen below the critical level of 3 milligrams per liter for game fish was recorded in the bottom layer during the summer.

Description of the dam and associated recommendations are in Appendix I. 
Recommendations

- Coordinate with DFW related to annual pH testing associated with stocking program, and development of recommendations for remedial treatment with DFW if necessary, to maintain the lake as a fishing resource. This might be the most efficient way to follow-up on Living Lakes Program testing and recommendations.

- Determine funding source for future lime treatments that may be called for under the clean Lakes Program recommendations and as indicated by ongoing $\mathrm{pH}$ testing.

- The narrow configuration of the lake presents a lack of surface area to adequately accommodate the full demand for motorized and nonmotorized recreation uses. A carrying capacity assessment should be conducted, establishing clear recommendations for quantity and timing for various uses.

- Assess whether the speed limit CMR is working to reduce potential user conflicts. Is there a pattern of accidents? Are the park staff receiving complaints? Are boaters complying with the CMR?

- Coordinate with residents, Boards of Health and DEP to use the new Title $V$ guidelines and funding sources to upgrade failing septic systems whenever feasible.

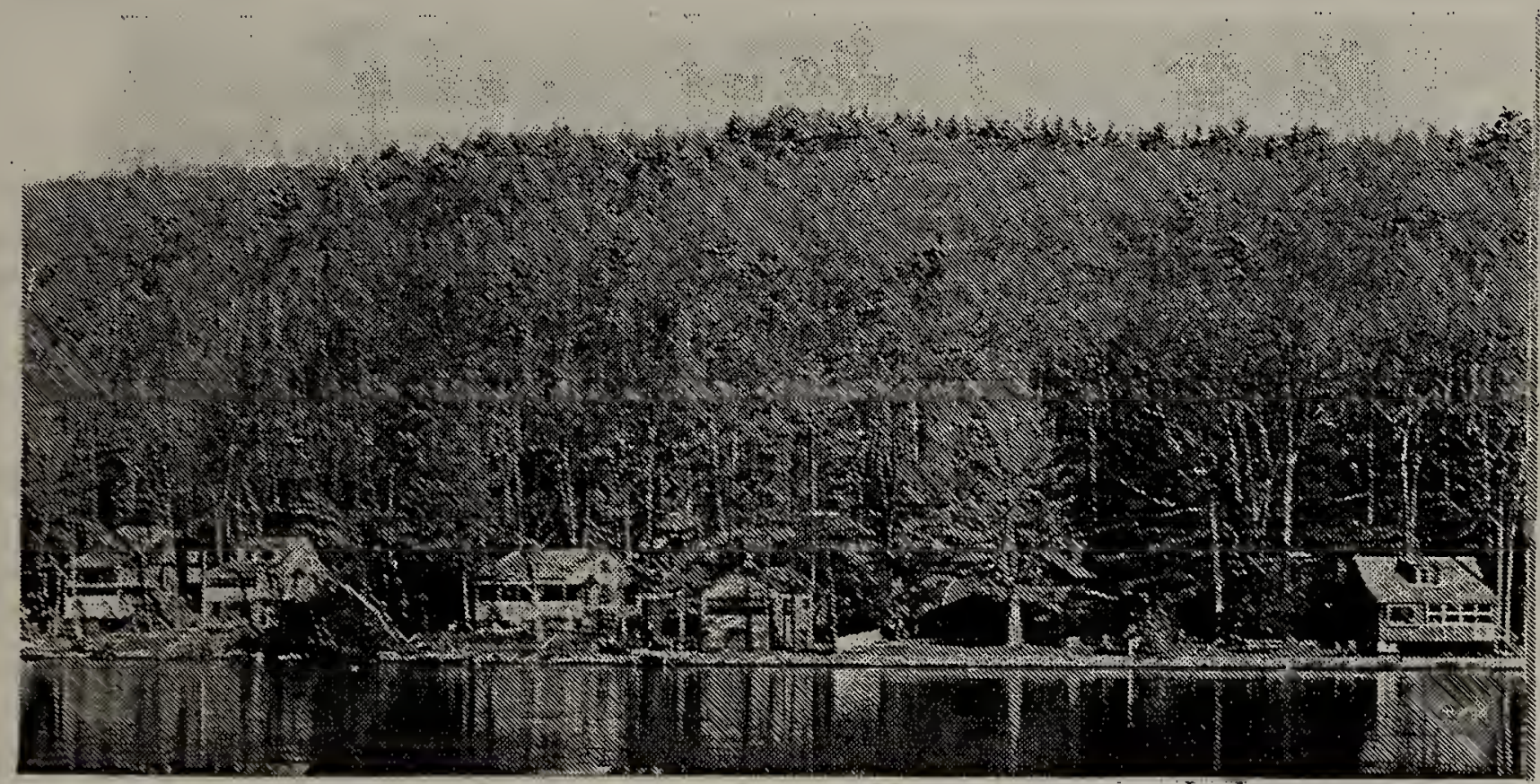

Cottages along the Laurel Lake shoreline. 
A dam across Tully Brook in Warwick impounds about 174 acrefeet of water that is known as sheomet Lake in Warwick State Forest. The lake has a surface area of 33 acres, with a mean depth of 6 feet and a maximum depth of 13 feet. It is also known as "Clubhouse Pond" by some residents. Sheomet Lake's shoreline is undeveloped, except for a gravel launch for trailer boat launching, a parking lot for approximately 20 vehicles, and an area at the southern end where initial beach preparation was conducted in the 1970s. Recreational use of the lake includes fishing, cartop boat access, and unauthorized swimming. The lake is dotted with several small islands, and the surrounding watershed is mostly forested hills located close to the New Hampshire border. Aquatic vegetation is sparse with some dense growth occurring near the north end inlets atop shallow deltas. In the fall of 1994, Sheomet Lake was characterized by eutrophic levels of phytoplankton as measured by an analysis of chlorophyll-a. The phytoplankton in combination with humic acids from the watershed result in only moderate water clarity. The Secchi Disc depth was found to be 1.5 meters with a humic brown water color. This level of water clarity is acceptable but not ideal for contact recreation standards. The phosphorus level of the lake was measured in three locations and ranged from 0.018 to 0.028 , which is also within the eutrophic range. The phosphorus and nitrogen levels are conducive to an abundant population of phytoplankton growth that decreases water clarity. The phosphorus appears to be originating from one of the two tributary streams. The level of dissolved oxygen is high throughout due to the lack of temperature gradient from the surface to bottom waters of this shallow lake. The moderate level of acidity allows for a healthy fish population and contact recreation, but the buffering capacity is low to moderate. The lake had a low to moderate specific conductance indicating that ions such as road salt are not a problem. This is probably due to protection afforded by the forested watershed with few roads near the lake.

A 1980 sample identified eight $\mathrm{f}$ ih species in Sheomet Lake (listed in order of abundance): brown bullhead, pumpkinseed, white sucker, smallmouth bass, gold shiner, eastern brook trout in the deeper waters, killifish, and American eel. The lake receives trout annually under DFW's stocking program.

Recommendations:

- The recommendation under Ruggles Pond for cost / benefit and recreation demand analysis should include analysis of sheomet Lake.

- Water quality data should be sampled again and compared with 1994 values in order to develop specific recommendations for improving water clarity and managing aquatic vegetation.

- The source(s) of phosphorus and nitrogen should be identified and inputs to the lake should be lessened if feasible.

- Recommendations for Sheomet Lake dam are listed in Appendix I. 
The 19-acre Ruggles Pond has a maximum depth of only 6 feet . Ruggles Pond is located in Wendell state Forest. The pond lies behind the state Forest Headquarters. There is a picnic area, walking trails, cartop boat access, and a swimming beach along the lake. The area is heavily used in the winter, with groomed snowmobile trails and sledding. Ruggles Pond is used for fishing and is especially noted for its beauty. The 787 acre drainage area has some roads, homes, and wetlands, but it is mainly state forest land.

Three management problems at Ruggles Pond are geese, beavers, and aquatic vegetation. An abundant goose population can contribute to bacterial water quality problems. The beavers have continued to block the outlet of the dam, despite efforts by the staff. Likewise, lily pads have been encroaching on the swimming area. In addition, the water clarity is below the minimum for swimming due to humic material and algal growth. This very shallow pond is an abandoned field that was filled behind a CCC dam. Stumps and other organic material were left behind, resulting in many of the water quality problems that exist today.

Ruggles Pond has a lack of water clarity and abundant aquatic vegetation. The water is acidic, ranging from a $\mathrm{pH}$ of 4.8 to 5.4 , and the buffering capacity is low.

The pond is eutrophic, characterized by abundant. macrophytes. Swimming quality is lessened by a lack of water clarity. The clarity is affected by humic acids from the. watershed, organic materials from the underlying terrestrial habitat soils, and by phytoplankton. Also, aquatic vegetation such as fragrant waterlily, bladderwort, watershield, and wild celery spread into the swimming area. Leeches also exist in the pond.

\section{Recommendations}

- This pond will only be feasible for long-term beach use if a permanent solution is implemented for water clarity and aquatic weeds. Conduct cost / benefit and recreation demand analysis of improving and maintaining this pond versus development of new facilities on another DEM-managed lake or pond.

- Long-term management of water clarity and aquatic weeds will require drawdown to dredge out the muck and terrestrial soil to the point where glacial sediments are exposed.

- If feasible the beach area should be supplied with its own water source to maintain adequate circulation.

- Coordinate with DFW related to management of local beaver population. 
Wickett Pond, located in Wendell state Forest, is approximately 30 acres in surface area. Somewhat out of the way, the pond can be accessed via an unpaved park road. A beaver dam has increased the depth of the pond, partially flooding the boat ramp and encroaching on a small parking lot. The watershed includes some homes and roads, but is mainly forested upland. It includes some vegetated wetland areas.

Wickett Pond is nearing the end of natural lake succession, making it uniquely beautiful and ecologically dynamic. The pond does not have an overabundance of nitrogen or phosphorus, but aquatic vegetation density varied from sparse to very dense in the late-summer 1994. Despite acidic water and dense growth of macrophytes, there is unauthorized swimming. Visitors also use the access point to put in cartop boats. DFW stocks trout in Mormon Hollow Brook, which flows out of the pond to the Millers River.

Wickett Pond was analyzed in late-summer 1994 as a possible alternative site for swimming in Wendell state Forest, but was found to be unsuitable for intensive water-based recreation. The $\mathrm{pH}$ of Wickett Pond is very acidic (below 5 in the late-summer 1994) with an extremely low buffering capacity. The acidity of the pond was at a level that made it unsuitable for most fish species, and could cause eye discomfort for swimmers. Despite some humic acid discoloration, the transparency of the water is good, as measured by a secchi depth of 2.5 meters. The nitrogen, phosphorus and specific conductance levels in Wickett Pond are very low, indicating that very little pollution is reaching the pond. Dissolved oxygen levels are high throughout the water column due to the lack of temperature gradient from the surface to the bottom of the pond.

Consistent with its successional status, wickett Pond has abundant aquatic vegetation. Some milfoil was found at wickett Pond, but it was a native species rather than an aggressive Asian variety. Bladderwort and pond lily are the most abundant plants. Wickett Pond has been a part of the landscape since the glaciers retreated. It is approaching the final stages of lake succession. Over the millenia the basin has gradually filled in with many meters of lake mud and it will eventually fill in completely unless natural successional trends are actively altered.

Recommendations:

- DEM management for water quality and recreation should allow the continuation of the pond's natural succession.

Regionwide Recommendations:

- All the lakes and ponds should be regularly monitored. The lakes and ponds within this study either are plagued by acidification, or are susceptible to acidification. Many of the lakes and ponds also have some problem with aquatic vegetation. Therefore, annual monitoring is recommended. 
- Coordinated monitoring and remediation can save time and money. Resources can also be shared to increase the efficiency and maintain the health of the lakes and ponds in this region.

- Install signs at all DEM-managed boat access sites encouraging boaters to remove plant debris before and after boats are launched, to reduce the spread of exotic and nuisance plants. Also, signs should alert boaters to properly clean their boats to remove zebra mussels, which may have been picked up in contaminated waters. Signs are available from the Public Access Board.

\section{SWIMMING SUITABILITY ASSESSMENT}

SCORP identifies a demand for water based recreation, particularly swimming, throughout the state. The lake and pond analyses described in this section allow for a swimming suitability assessment.

Current

Status

Authorized

Swimming
Lake / Pond Beaman Pond

Beaman Pond

Lake Dennison - Potential sanitary problem

- Water clarity

- Phytoplankton
Hindrances

Solutions

-Drawdown, monitor, and supplement buffering capacity

- Comfort station rehabilitation \& fall pumping of septic tanks

Dunn Pond

- Eutrophication

-Water clarity

Laurel Lake

-Motorized boat safety

- Leaking septic systems

Unauthorized Swimming

Sheomet Lake

- Phytoplankton

- Chlorophyll

-No facilities

Ruggles Pond

- Water clarity

-Aquatic

vegetation

-Beavers

No Swimming
- Ongoing mainenance of stump Pond

-Speed limit enforcement -Septic upgrades

- Construction of swimming and recreation area if justified by supply and demand

-Draining, dredging to glacial soil, and finding fresh water source for swimming area

-No swimming area development

\author{
Wickett Pond -Aquatic \\ vegetation \\ - Very acidic \\ -Beavers
}


In addition to the preceding detailed lake and pond analyses, the following descriptive information is provided for two important water bodies, which are located within this planning region.

Richards Reservoir is located in Warwick. Approximately 58 acre-feet of water is impounded by the Richards Reservoir Upper Dam, situated on Black Brook in the warwick state Forest. The reservoir is 4,000 feet long and reaches a maximum width of 500 feet, creating a total surface area of 35 acres. The average depth is 1.9 feet, with a maximum depth of less than 10 feet. The reservoir's drainage area is .88 square mile.

The reservoir's primary recreational use is fishing. The reservoir is stocked with game fish by the state Department of Fisheries and Wildlife. There are no beach areas, picnic grounds, campsites, or private homes around the reservoir.

Ricevilie Pond is an impoundment created by a dam across Nelson Brook within Petersham state Forest. The site is a scenic resource enjoyed by occasional hikers. The bulk of the pond lies in Petersham, with a small portion extending into Athol that includes the dam. The shallow pond has a surface area of 68 acres and a volume of approximately 187 acre-feet under normal conditions. The dam is 15 feet in height, and when it was inspected in 1987 was found to be in good condition, and was categorized as low hazard.

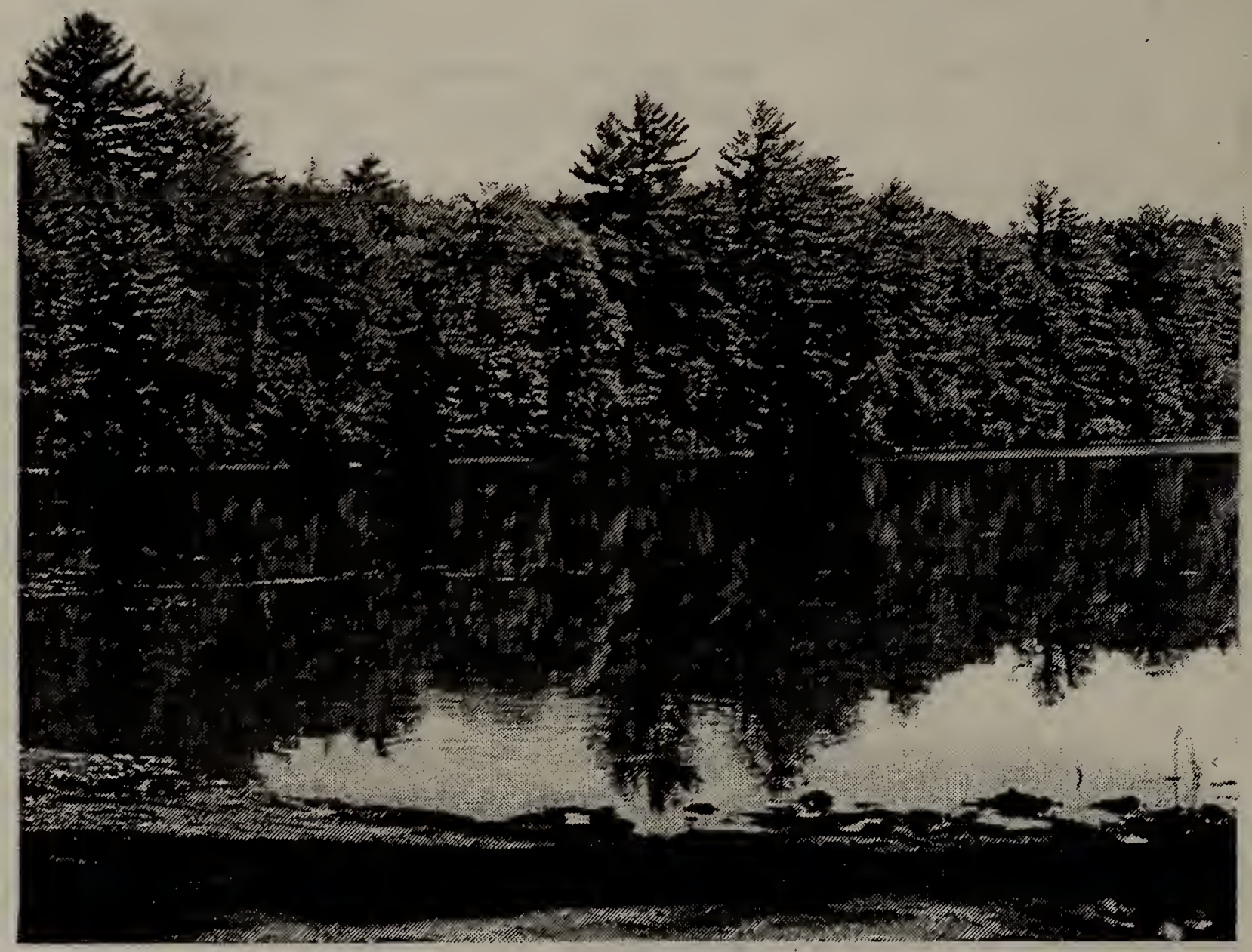




\section{RECREATION}

\section{BACKGROUND}

This cluster of parks has substantial opportunities for swimming, fishing and boating, including the use of Laurel Lake in Erving SF, Dunn Porıd, Lāke Dennison, Beamon Pond in Otter River SF and Ruggles Pond in Wendell SF. Sheomet Lake or Clubhouse Pond in Warwick SF also sustains considerable public use, but on a more informal basis. The formal water-based recreation facilities are all at capacity during the July 4 th and Labor Day weekends if the weather cooperates. Laurel Lake is the closest to capacity on a more regular basis, having to turn away visitors on several nice weather weekends each season. In the winter season Dunn Pond offers an excellent site for ice skating at the eastern end of the cluster.

The camping areas located in Erving State Forest (32 sites), Otter River State Forest (100 sites and three group sites) and Lake Dennison Recreation Area (150 sites) provide large wooded campsites in a scenic setting. Families that camp in these areas tend to enjoy their visit so much that they return year-afteryear. The large tracts of conservation land are characterized by abundant game and nongame wildlife, and are therefore an important resource for hunters and individuals interested in photography or quiet nature observation. Due to its location and topography, the snow conditions, along with the Berkshires and the Mohawk Trail corridor, are the best in Massachusetts. All of these important public recreation resources are located only an hour to an hour-and-a-half from Boston. The chart on the following page highlights the variety of recreation opportunities that are available in these parks.

A substantial percentage of the individuals who attended the initial public meeting for this GOALS plan brought ideas and suggestions related to trail use. This clearly demonstrated the importance of all-season trail opportunities in the north-Quabbin region. A working group to address trail issues was formed from public meeting attendees and other interested people. Trail opportunities and recommendations are covered separately in the following chapter of the plan. 
$\overline{\text { Gardner Heritage State Park }}$

$\overline{\text { Dunn Pond State Park }}$

$\overline{\overline{\text { Otter River State Forest }}}$



Lake Dennison Recreation Area

Federated Women's Club State Forest

\section{Erving State Forest}

$\overline{\text { Wendell State Forest }}$

Mt. Grace State Forest

$\overline{\text { Warwick State Forest }}$

Accessible Restrooms

Bicycling Paths

Boating (motorized)

7 Huning (restrictions)

Interpretive Program

Eig (seasonal)

M. Leashed Pers Allowed

A. Camping

$\overline{F_{F}}$ Picnicking
$A$ Bouting (non-motorizẹd)

$\Longrightarrow$ Boat Ramp

Restrooms

6 i

0.0 Scenic Viewing Area
E⿴囗大国雨

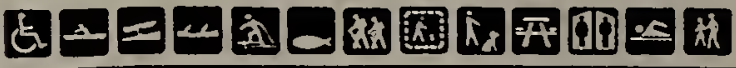

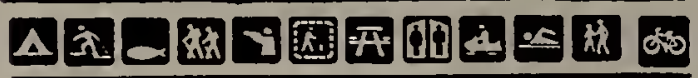

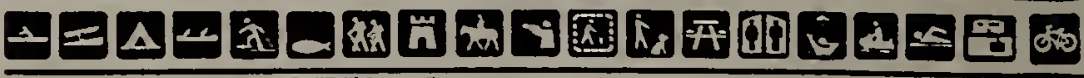

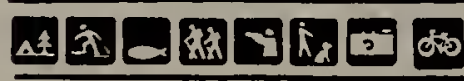

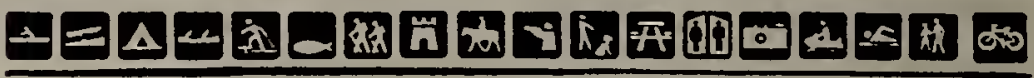

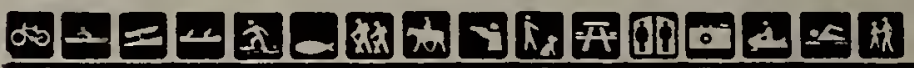

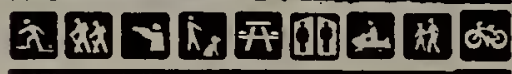

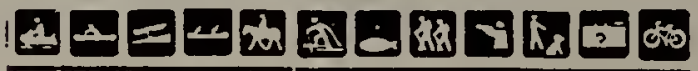




\section{GOALS VISITOR SURVEYS}

During the summer of 1994 a visitor survey was distributed to campers, and also conducted in interview fashion with day users. The parks covered by the survey are Dunn Pond SP, Lake Dennison SP, Otter River SF, Erving SF and Wendell SF. The number of surveys returned does not allow for formulation of quantitative results from full statistical analysis, but does indicate some characteristics of our park visitors that can help DEM gain insights to improve our delivery of visitor services. Along with the following text description, a table summarizing the survey results is provided in Appendix E.

The return rates for the surveys ranged between ten and twenty percent. Most of the visitors had learned of the state park opportunities from family or friends. Road signs and maps, DEM brochures, tourism brochures and local media were less important but consistent sources of information. There was no clear distinction between day users and campers or between parks related to the number of years that visitors had been returning to the DEM facilities. Overall, the visitors were fairly evenly distributed between those who were on their first visit, those who had been coming to the park for one to five years, and people who had been regular visitors for more than five years.

The day users originated mostly from local communities and other locations in central Massachusetts or along the Route 2 corridor. The campers came to the facilities from greater distances. Only one-quarter to one-half of the campers came from local communities. Approximately one-half came from the greater Boston area or other locations in eastern Massachusetts, and ten to fifteen percent came from abutting states.

The day use visitors came to Dunn Pond, Lake Dennison and Ruggles pond mainly to swim and have a picnic, but taking a walk or a hike while they were in the park was an activity enjoyed by more than half of the visitors. Fishing and boating are also popular activities as indicated by a lesser but consistent percentage of the responders. It is interesting to note that ten percent of the visitors who were surveyed at Dunn Pond indicated they had attended outdoor band concerts in the city. The band concerts are organized through the efforts of DEM's Heritage Park staff. Also, more than twenty percent of survey responders indicated skating at the pond as one of their recreation activities. This is a sizable percentage considering that the survey was administered during the summer.

A survey distributed in the Wendell Post sampled a different group of state forest users, people not as likely to be found at the Ruggles Pond day use area. The responders to this local newspaper survey were most interested in non-motorized trail use in DEM forests and parks. Hiking, nordic skiing and bird 
watching were the most popular activities mentioned by two-thirds or more, swimming and picnicking were checked by about half the respondents, and a moderate activity level was indicated for mountain biking, skating, camping, fishing and boating at Wendell state Forest or other DEM parks.

A total of forty eight campers, staying at campgrounds in Erving State Forest, Lake Dennison Recreation Area and Otter River State Forest, responded to the survey. Swimming and picnicking, along with the opportunity to camp, are the primary reasons that people come to these DEM campgrounds. The visitors often walk and hike during their stay, and about one-third indicated that they take advantage of opportunities for fishing and boating.

The campers survey also questioned the park visitors as to what they were doing outside the park, providing a window on products and services they might be purchasing in nearby communities. This allows us to get a sense of tourism related benefits to the local economy, generated as a result of people visiting DEM parks. Survey responses indicate that more than half of DEM park campers in this region patronize grocery stores, restaurants and retail stores. The day use visitors also purchase local services, but not as frequently as the campers. The staff of Gardner Heritage SP in cooperation with the Greater Gardner Area Chamber of Commerce have noticed a particularly strong connection between attendance at the Heritage Visitor Center and visits to the local furniture outlets.

\section{SANDLER ASSOCIATES SURVEY}

In 1995 DEM contracted with Richard Sandler \& Associates to conduct a Recreation Consumer Attitude Survey and a Camping Consumer Attitude Survey. Respectively, the purpose of these surveys was to learn more about the interests and desires of the "outdoor recreation public" in Massachusetts, and to learn more about the habits and preferences of people who regularly go camping in the northeast. The long range objective is for DEM to use the survey results to increase its responsiveness to its potential park visitor market.

A summary of the recreation survey indicates that walking, picnicking, swimming and hiking are popular activities with more than 50\% of the respondents. Historic appreciation, biking, nature study, fishing and camping are also very popular, having been mentioned by one-quarter to one-half of the respondents, perhaps reflecting more specific interest groups. Summer is the dominant season for use of the parks, but spring and fall are not far behind, and about one-third of the respondents use the parks during the winter months. This is particularly significant related to this plan that covers an area with winter conditions that afford excellent cold weather recreation opportunities. 
The recreation survey and the camping survey both indicate that the most important services we can offer to visitors include a knowledgeable and friendly staff, and ample information about the parks.

The camping survey determined that preference between public and private campgrounds is evenly split, autumn and spring camping are surprisingly popular with 4 out of 5 campers likely to go camping at that time of year, weekend trips are more popular than camping vacations, and tent camping is the most popular type of camping. When deciding where to camp, cleanliness, safety and an attractive setting are considered to be the most important criteria. This speaks well for Massachusetts Forests \& Parks, because overall Massachusetts ranked high in the northeast as a popular camping destination, tying with New Hampshire and New York. The following facilities are considered important by more than two-thirds of the camping public; hot showers, fire places, self-guided nature trails, swimming facilities, picnic tables, information/education center, park store, water at the site, play fields, and universal access enhancements. Finally, the camping survey indicates that cabins would be popular if facilities were available. Most campers have never camped in a cabin, but more that 4 out of 5 would like to try it in the future.

Marketing recommendations from the Richard Sandler \& Associates surveys are incorporated with the recommendations at the end of this section.

\section{VISITOR ATTENDANCE}

Using one park (Lake Dennison) from the eastern end of the cluster, and one park (Erving) from the western end, data on numbers of day users and campers in 1984, 1989 and 1994 is shown in the following bar graphs to highlight recent trends in visitor attendance. The greater number of visitors at Lake Dennison is simply a reflection of the capacity of he facility. In this subjective analysis one must also take into account the weather, because overall visitor attendance during a cloudy cool summer will be less than attendance during a year with many warm and sunny weekends.

There is no outstanding trend in number of campers at either of these parks. The graphs reflect camping facilities that maintain a fairly steady attendance rate with both parks at or near capacity for most of the summer. The decrease in number of paid day users in 1994 may reflect the decreased ability to cover and charge a fee for day use facilities due to reduced staff numbers. Although data on number of nonpaid day users is an estimate from park staff, the estimates from both facilities show a trend towards a decrease in attendance. This could be a reflection of weather factors for the years used in this analysis, or it could reflect a trend in public use of these facilities and dispersed recreation activities in general. 


\section{LAKE DENNISON STATE PARK VISITOR ATTENDANCE}

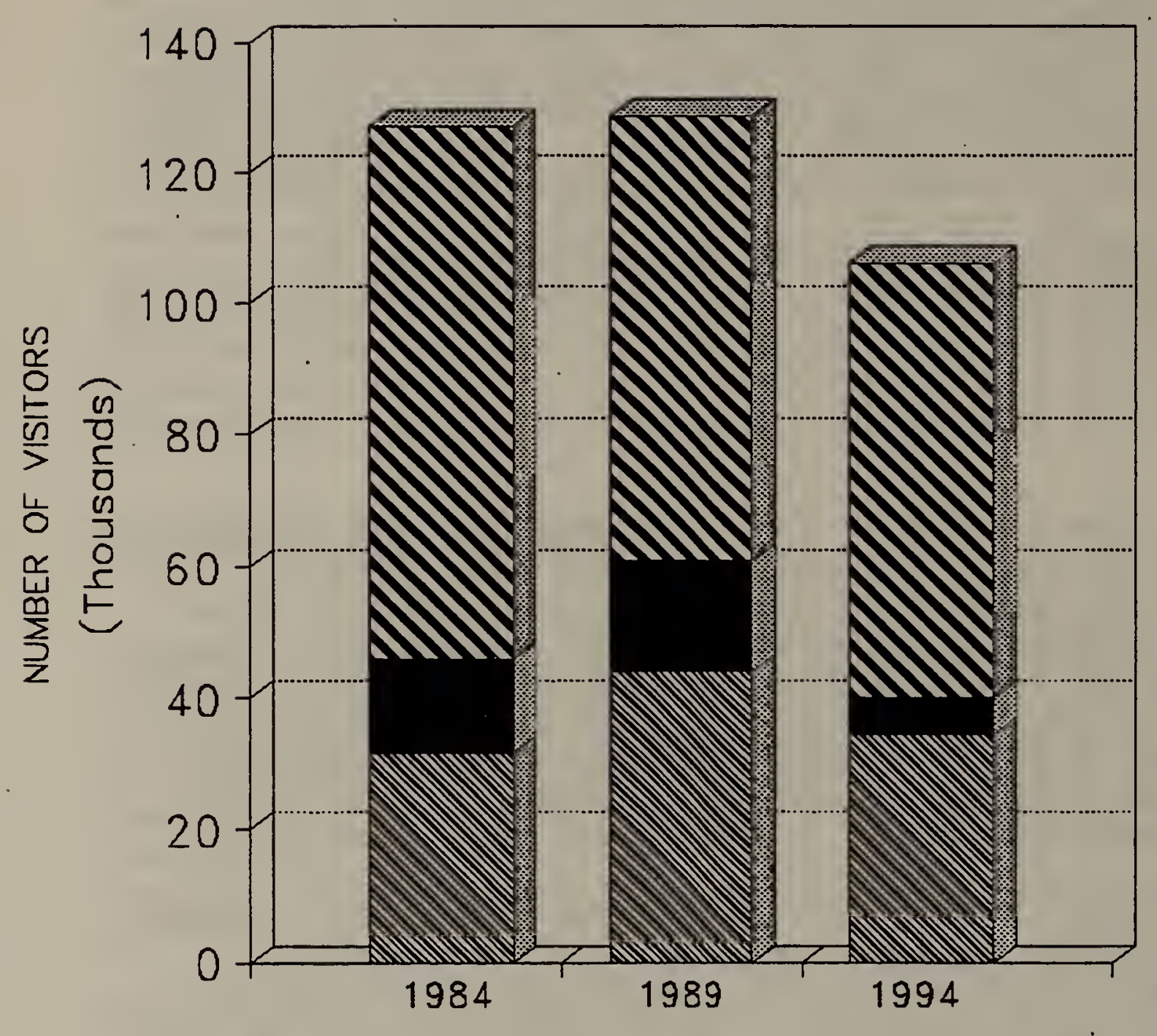

\begin{tabular}{|ll|}
\hline ESTIMATED \\
DAY USERS & (NONPAID) \\
DAY USERS (PAID) \\
CAMPERS
\end{tabular}




\section{ERVING STATE FOREST VISITOR ATTENDANCE}

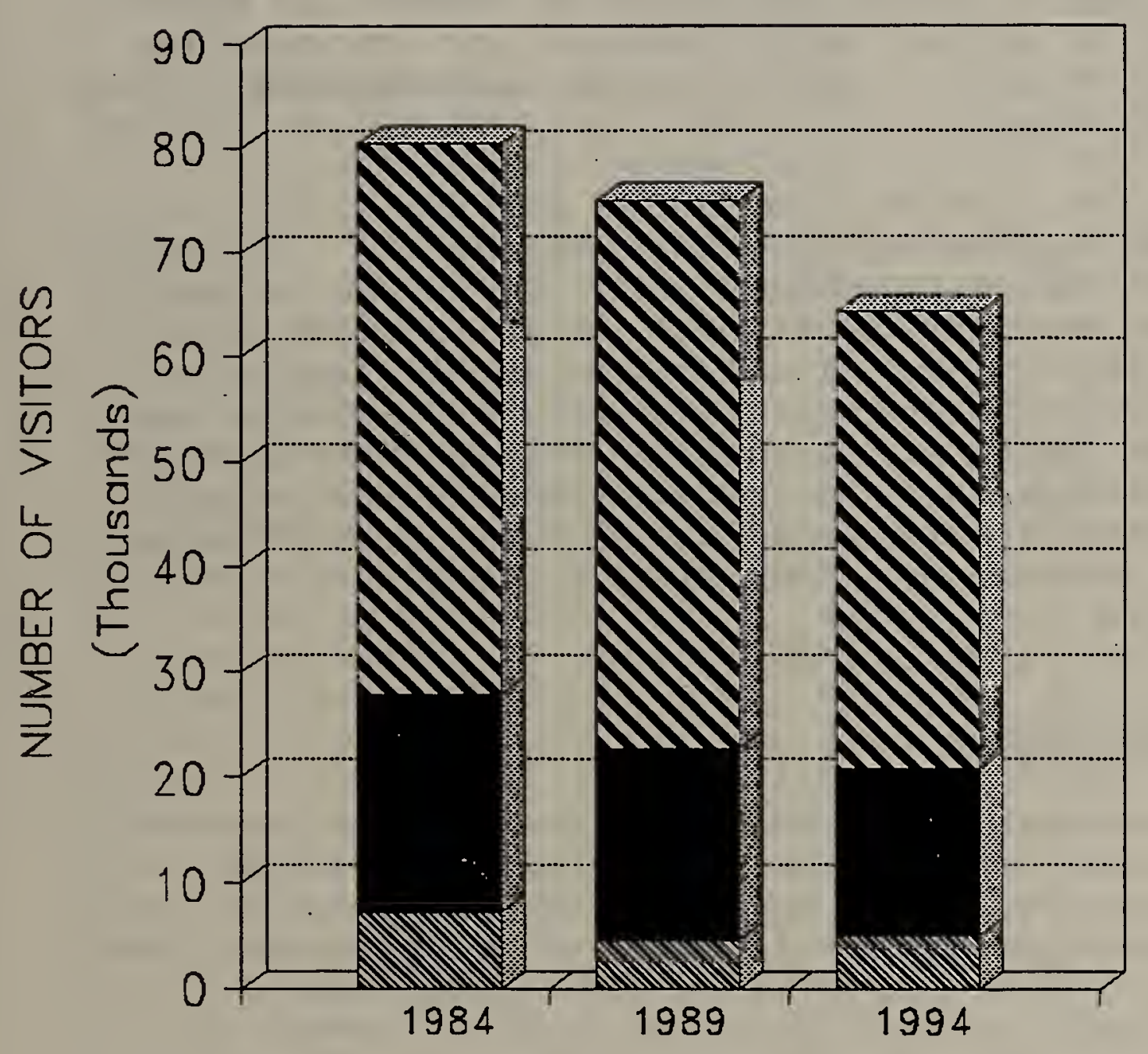

DAY USERS (NONPAID)
DAY USERS (PAID)
CAMPERS


In order to qualify for Federal Land \& Water Conservation Fund allocations, Massachusetts must develop a statewide Comprehensive Outdoor Recreation Plan (SCORP). The plan is renewed on a five-year basis and includes an analysis of recreation supply and demand, with the data separated by regions that are mostly defined by county boundaries. The coverage area of this GOALS plan is a small subregion within the Central Mass. (Worcester County) and Connecticut River Valley (Franklin, Hampshire \& Hampden Counties) SCORP planning regions. SCORP analysis (1988 - 1992) for this coverage area indicates a demand for water-based recreation such as swimming, fishing and boating, and increasing access to waterways. SCORP also recommends expansion of hiking and nordic skiing opportunities, and improving the image and public awareness of state-owned and operated facilities with particular emphasis on facilities which provide picnicking, hiking, fishing and boating. There is also an indication of a need to expand opportunities for ice skating and field-based activities and to actively promote existing opportunities for ice skating.

Initial analyses from a survey conducted for the $1995-2000$ SCORP indicate that, in comparison to other regions in Massachusetts, responders from the Connecticut River Valley and Central Mass. express a need for facilities offering picnicking, camping, swimming, hiking, nordic skiing and mountain biking. The results show that responders from all areas in the state most often become aware of recreational resources either from family and friends, or from newspapers. The recent SCORP survey also reveals that, related to state funding initiatives, individuals are most supportive of maintenance, rehabilitation and improvements for existing facilities.

\section{MANAGEMENT GOALS AND OBJECTIVES}

.8

DEM will strive to provide visitors with modern yet rustic recreation facilities in a safe, clean environment. Visitor services will continue to include a great variety of recreation activities, outdoor educational experiences, and a chance to just find a peaceful place to relax and draw in some fresh air.

In order to effectively provide these services, and to enhance recreation opportunities, DEM will seek advice from organized user groups, individual park visitors, neighbors and the surrounding communities. 
Camping: The Erving state Forest campground has 32 campsites, which do not meet the full demand for camping at this park or on a regional basis.

- Expand campground by 22 sites with corresponding infrastructure improvements. Initial plans for expansion are shown in the accompanying diagram (Figure 4).

- Determine area(s) appropriate for wilderness campsites.

Cabins: The cabins at Savoy Mountain state Forest and Mohawk Trail state Forest are very popular. They are completely booked from April through October, and also full during weekend throughout the year. The suitable site conditions, accessibility from the headquarters area, proximity of Metacomet-Monadnock Trail and popularity of nordic skiing are factors that make Wendell state Forest ideal for addition of cabins/yurts (Figure 5). Final site selection to be reviewed by DFW-NHESP.

Nordic Ski Center: Assess potential for public-private partnership using the trail system in wendell state Forest. Initiate with advertisement and request for letters of interest.

Swimming: Assess options for increasing opportunities for swimming. Criteria for assessment includes water quality, distance to population centers and regional demand for water contact recreation, costs for swimming facility rehab or improvements, and water quality enhancement. The following alternatives are listed in order of priority.

- Acquisition and development of Lake Wyola site in Shutesbury would distribute availability of water-based recreation towards an area where population density is greater and therefore demand. will also be greater.

- Rehabilitation of facilities and water quality improvement for Ruggles Pond in wendell state Forest. This site is fairly close to population centers and the facilities are already present.

However, long-term water quality management would require a major dredging project to remove the forest soils that were not cleared from the site prior to the dam construction that initiated the pond. A project of this scope would require a great deal of environmental review at the local level and through DEP and the MEPA process.

- Development of facilities at Sheomet Lake/Clubhouse Pond. Even though initial beach site preparation was conducted by DEM in the 1970s, this lake is not very close to population centers and would require major capital investment to develop new facilities.

Skating: Establish a skating area to cover public demand at the western end of the cluster. Flooding the Mt. Grace state Forest recreation field is one possible option if staffing levels allow for increased winter coverage. 


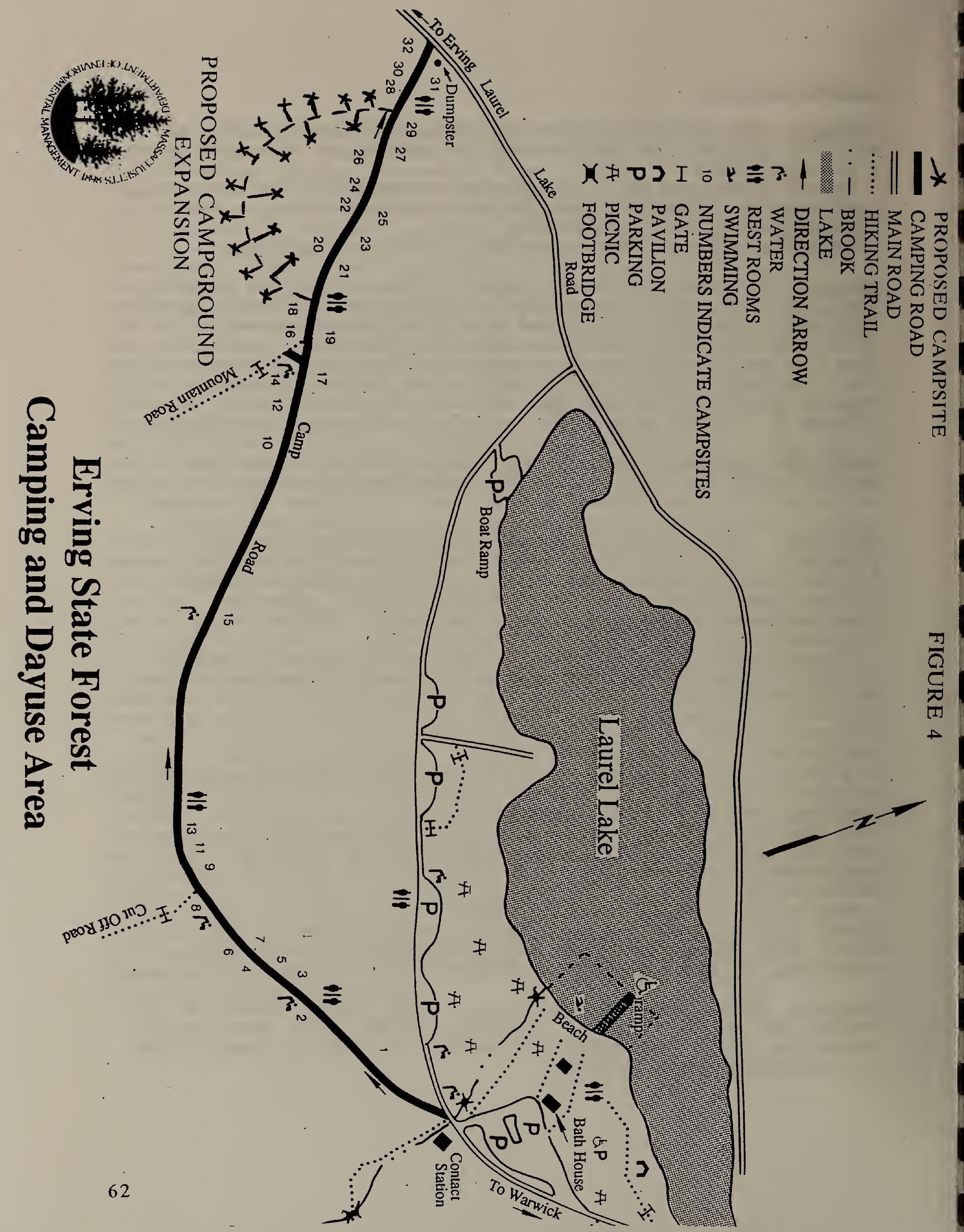


FIGURE 5

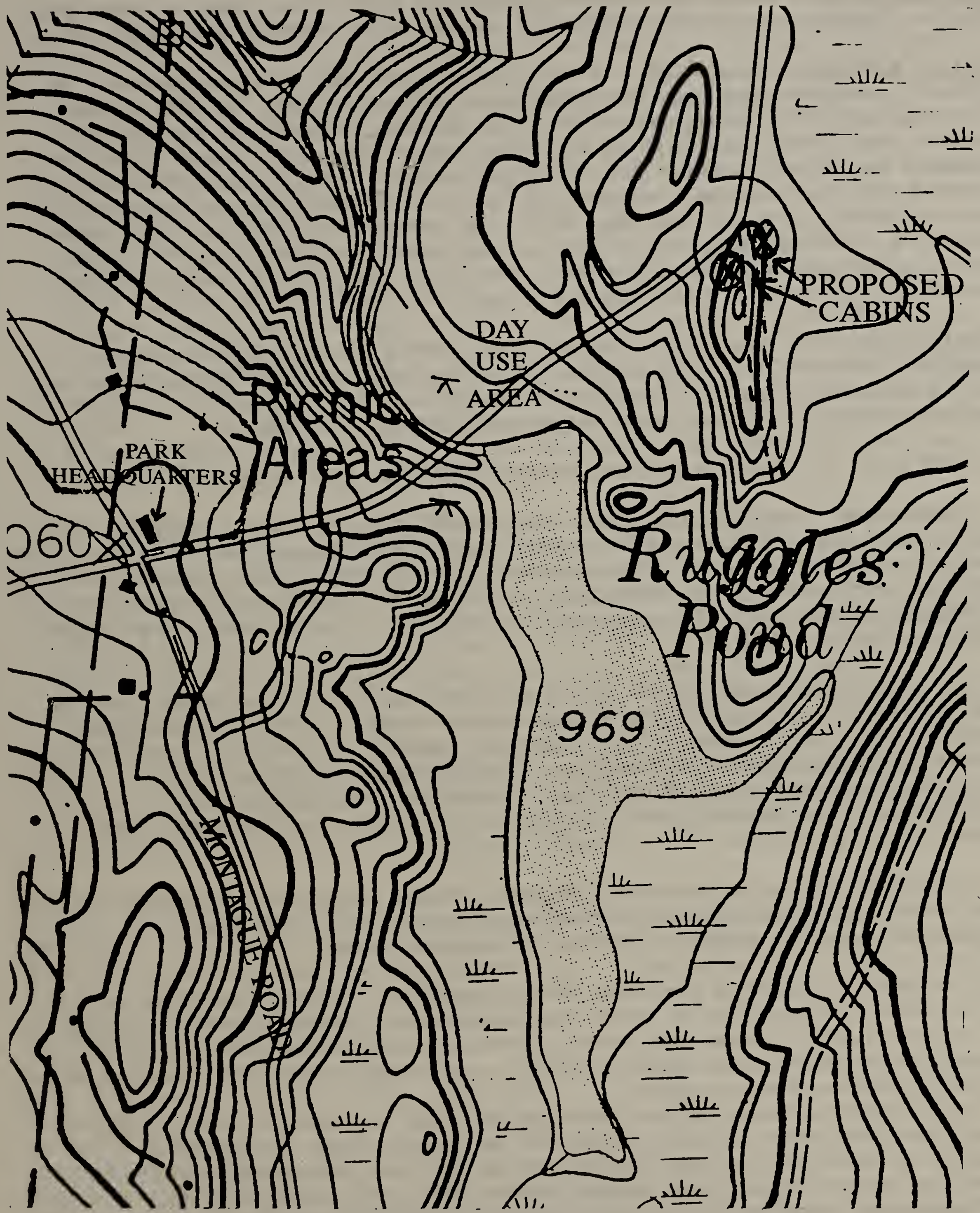

Wendell state Forest cabin development proposal. 
Boat access: Establish boat access at Riceville Pond - Petersham State Forest, combining DEM work and Public Access Board funding.

River access: Coordinate with the Millers River Watershed Council to promote and provide more public access to the river. The Route 2 corridor westward from wendell can be promoted as a canoe route with access to the Millers River from Wendell state Forest or other points. With a portage at the Turners Falls Dam, canoeists can access Connecticut River Greenway State Park and canoe path. A list and map of river access sites from the 1983 Millers River Management Plan is included in Appendix F. Also, detailed canoe access information is included in a canoe guide available from the Watershed Council.

Marketing: To provide, within the limits of the natural and cultural resources, the highest quality recreation experience for the greatest number. An important spin-off can be a strengthening of the local economy through tourism.

- Continue to use interpretive programs as a promotional tool.

- Communicate with publishers of travel guides (AAA, Mobile, etc.) to expand coverage of state park opportunities. Increase availability of brochures and information on. special events in Chambers of Commerce, Offices of Travel \& Tourism, along highway stops in neighboring states, and at sporting goods stores such as EMS.

- Through the Great Falls Discovery Center at the western end of the cluster and Gardner Heritage state Park at the eastern end (contingent on increased programming capability with a Visitor Services Supervisor in Gardner) develop partnerships with regional working groups such as the Greater Gardner 2000 Committee, for events \& interpretive programs, and market the events and programs.

- Continue to upgrade DEM's Internet Home Page for the benefit of Net surfers, providing information related to recreation opportunities in Massachusetts Forests \& Parks.

- The recent surveys provide some insight on ways that DEM can focus marketing efforts to increase visitor attendance. Increase in camping would have the most positive effect on the local economy, because overnight visitors are most likely to purchase local goods and services.

- The GOALS visitor survey indicates that a significant number of campers come to this cluster of parks from the greater Boston area and other locations in eastern Massachusetts, while most of the day users come from local communities. Therefore, marketing in the greater Boston area and eastern Mass. might be the most effective way to increase day use attendance by providing information about winter and summer 
recreation opportunities "only one hour west of Boston", and also increase camper attendance by marketing in a densely populated area where we already know there is strong interest for camping along the Route 2 corridor. The marketing for camping should be focused to increase weekday attendance. - The Sandler Associates recreation survey suggested that there are many "light users", i.e. people who visit recreation facilities only a few times per year. Visitor attendance could be increased significantly if light users would come to the parks just a few more times per year. Sandler Associates recommended marketing specifically for the light users. It is possible that marketing in greater Boston and eastern Mass. might be the most effective way to reach this potential market, because the densely populated nature of the area indicates that there are more people of every variety, including ones who could be considered light users of recreation facilities. The camping survey found that camping is mainly a young person's pursuit. The median age of the camping population is 29 . Only $6 \%$ are over the age of 55. This is useful information for any outreach effort aimed at DEM's campground visitors.

- The Sandler Associates survey indicates strong public interest related to visiting and learning more about historic and cultural sites. Sites within the state forests might be appropriate for interpretive programs that could be marketed in the region or statewide. Potential sites within this cluster of parks include: - Native American sites such as prehistoric villages, a Cólonial Period tribal council meeting location, camp locations. - Mill, tannery and house sites from the colonial through - Industrial Periods (late-1600s thru early-1900s). - Civilian Conservation Corps sites.

Note: A professional determination of the significance and integrity for any historical or cultural site, with development of a treatment/protection plan, would be required prior to establishing public visitation procedures.

- The Heritage Discovery Network database, developed by DEM's Office of Historic Resources, provides an avenue for DEM to increase the public's awareness of natural, scenic, cultural and historic attractions of Massachusetts. The Network has a unique focus on "second tier" heritage attractions-those sites which are most often missed in conventional tourist promotion. The database includes detailed information on sites in Franklin County along the Mohawk Trail. As additional sites are added to the database, and the data availability becomes more tourist-user friendly, DEM should take full advantage of this new tool to promote recreation opportunities for this cluster of parks. The database is accessible at the Great Falls Discovery Center in Turners Falls. The sites that are currently covered in the database are listed in Appendix G. The following is an example of Short Site Detail Reports from the Network database, presented as a customized visitors guide. 


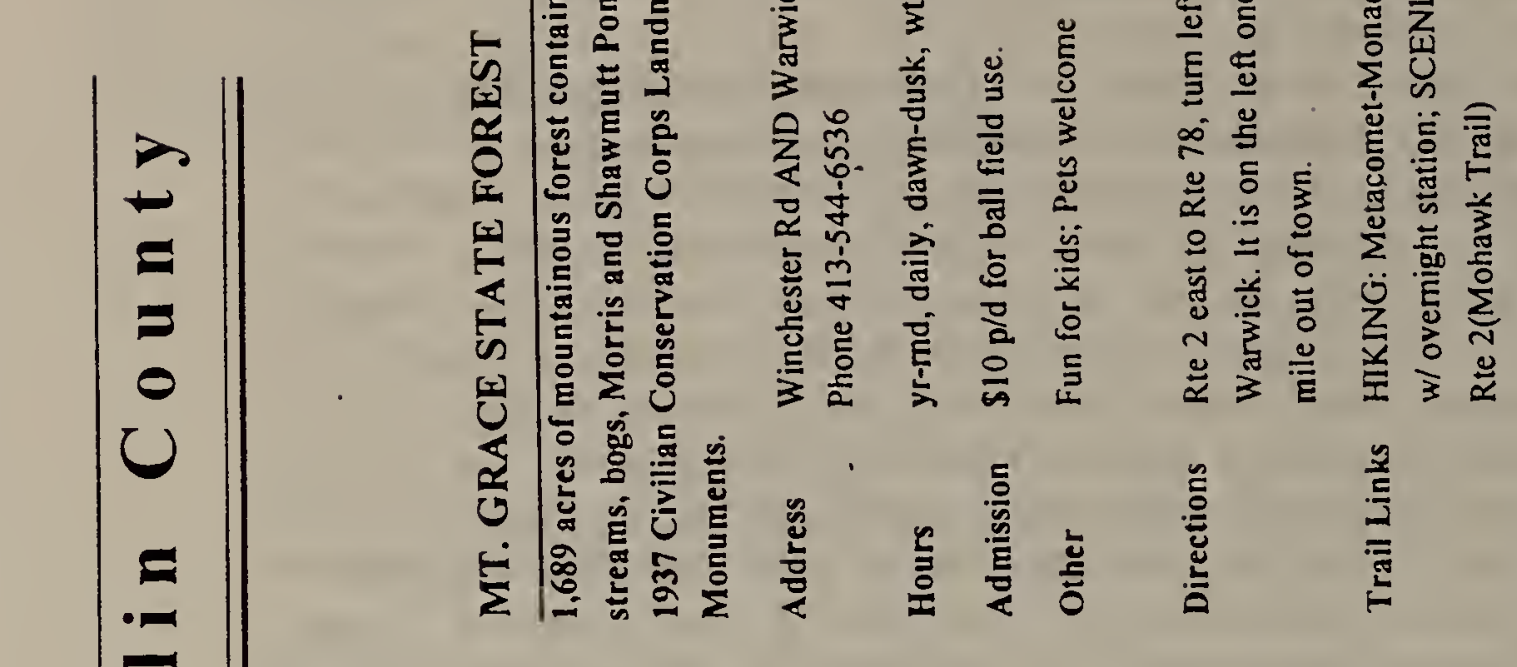

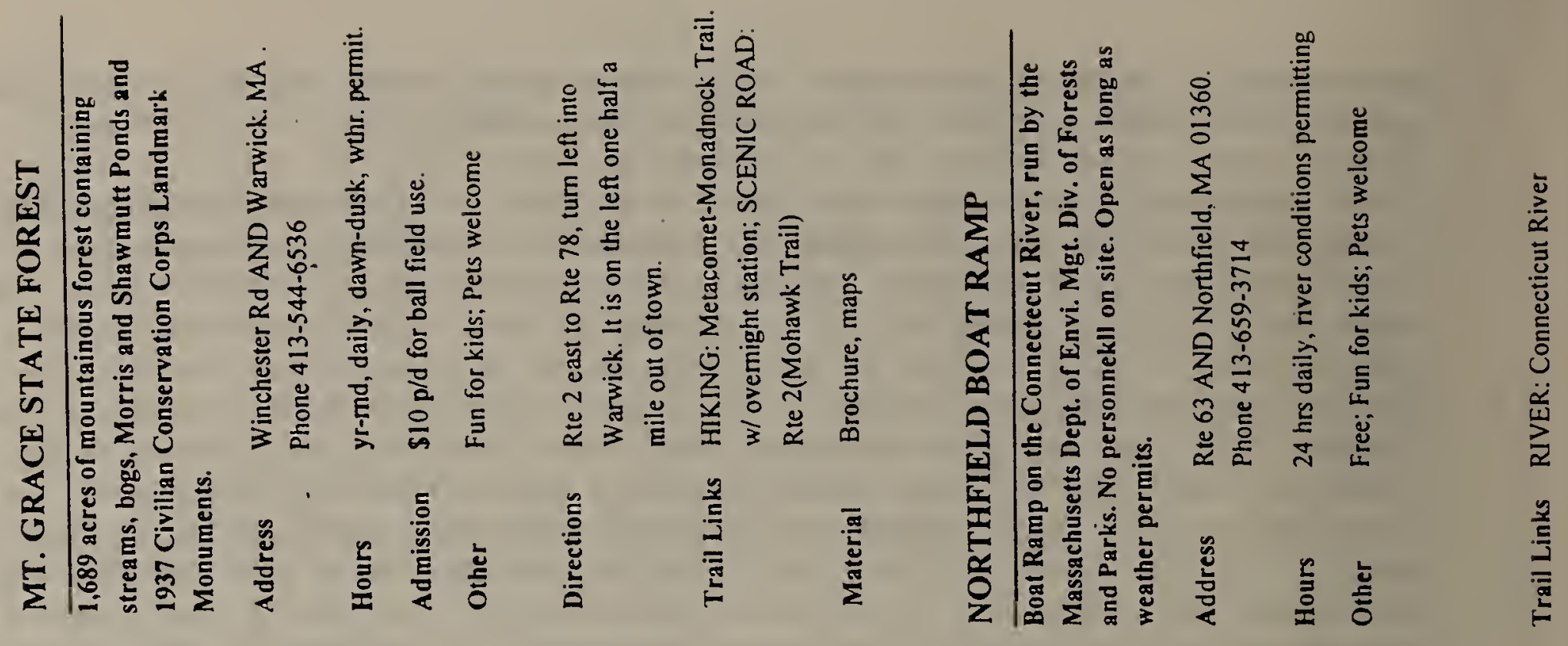
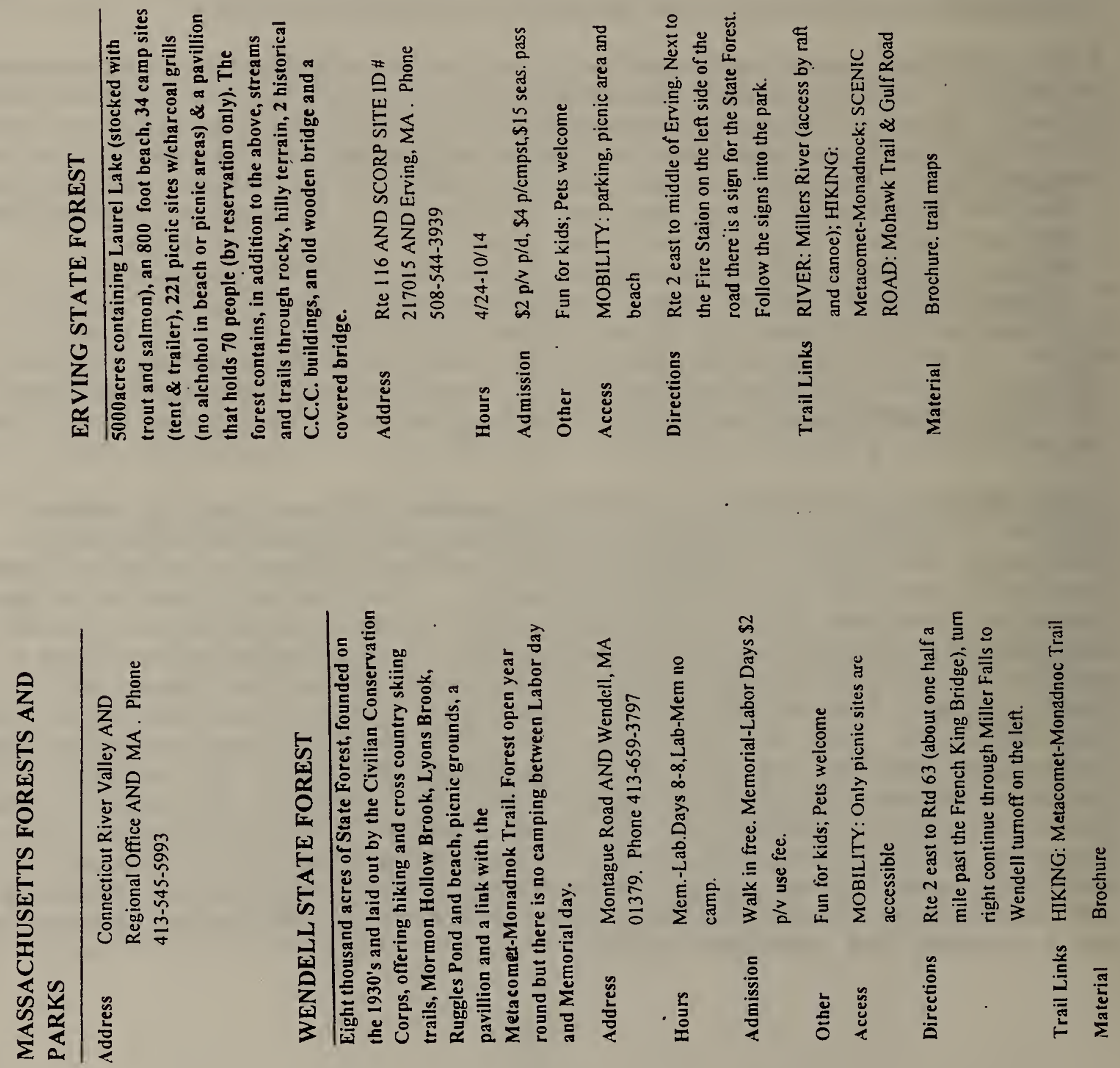


\section{TRAILS}

\section{BACKGROUND}

The trail network within the thousands of acres of DEM forests and parks in eastern Franklin county and northern Worcester county provide people with hundreds of miles of scenic paths for a variety of uses in all seasons. There are substantial public benefits in terms of physical and mental health because the trails are an invaluable resource for exercise, solitude, fun with friends and family, and enjoyment of the outdoors traversing a beautiful landscape.

In addition to the extensive trail mileage located within the forests and parks, the study area is bounded at the eastern and western ends by well-established long-distance trails, and also includes a trail corridor in a former railroad ROW that was recently acquired by DEM. Specifically, at the eastern end of this planning region, the Midstate Trail runs from Mt. Watatic on the New Hampshire border all the way through to Douglas state Forest near the Massachusetts/Connecticut/Rhode Island boundary. The Midstate Trail is maintained by volunteers organized by the Midstate Trail Committee in coordination with DEM - Region 3 Forests \& Parks staff. The Ware River Rail Trail is also a north-south oriented corridor located near the eastern end of the region covered in this plan. It is approximately $15 \mathrm{miles}$ long, extending from the Baldwinville community in Templeton, southward through portions of Phillipston and Hubbardston, with its southern terminus in Barre. The Metacomet-Monadnock Trail traverses a north-south corridor from connecticut to its northern terminus on Mt. Monadnock in New Hampshire. The trail passes through several of the DEM forests along the western end of this planning region. The trail is maintained by Appalachian Mountain Club volunteers, with DEM cooperation being especially important throughout the extensive state forest sections.

The many scenic country roads in this area provide opportunities for bicycles and horseback riding especially in areas where unpaved roads connect with the trail systems in public and nonprofit conservation areas. Snowmobilers and nordic skiers also benefit from these informal trail connections due to the excellent snow conditions in this region.

\section{MANAGEMENT GOALS AND OBJECTIVES}

DEM's primary objective is to maintain a trail system within the forests and parks that provides for public safety and enjoyment without allowing deterioration in conditions of the natural and cultural resources that the Department is also mandated to conserve for future generations. 
Stepping back and looking at the region as a whole, there are opportunities to establish a network of connector trails between DEM forests and parks and other conservation areas with a focus on east-west oriented corridors.

DEM will strive to achieve these goals by seeking advice and working cooperatively with state park visitors, nonprofits, local communities, private landowners and other government agencies.

\section{RECOMMENDATIONS}

- The state forests \& parks within this cluster were evaluated as to suitability for ORV use and, based on the established criteria, all were found to be unsuitable for wheeled-motorized use.

- All non-motorized trail uses and snowmobiles shall be permitted on main trails, trunk trails and connector trails unless posted closed with appropriate signage, or prohibited by special regulation. (CMR)

- Trails and ways may be posted closed to one or more use(s) with signs at trailheads, intersections, or prominent locations such as the forest headquarters or visitor centers. With oversight from the Regional Forest \& Park headquarters, Forest Supervisors will have the authority to temporarily close trails during mud season or during times of extreme fire danger. conditions. (CMR)

- Enforcement of trail regulations will be enhanced in several ways :

- DEM will strive to improve communication and promote environmental education for our visitors.

- DEM will communicate information to DFW Environmental Police Officers' related to trouble spots and specific incidents.

- As of 1996, thirty five Forest \& Park Supervisors were authorized to write non-criminal citations. An additional group will receive the training in 1997. This authority is used in a non-confrontational and educational manner. The Park Rangers also provide educational programs and visitor services such as first aid and technical user information. The primary focus of a Park Ranger, in addition to their park supervisory responsibilities, are patrols for campgrounds, day use areas and trails, and visitor contact for educational purposes.

- DEM's Park Ranger Program training brings supervisors to a higher level of law enforcement capabilities.

- Forest Supervisor with the assistance of trail volunteers should establish more loop trails or improve existing loop trails within the DEM properties. Where possible, work with dog sledders to establish loops with open gates or without gates. Some inner loop trails may be designated for specific uses. 
- All parks should consider installation of a short, self-guided interpretive trail.

- Interpretive trail(s) through recent timber operation sites can demonstrate Best Management Practices (BMPs) used in forest management. The harvesting site near the Wendell state Forest headquarters is one ideal area to establish this type of trail.

- Place signs at trail intersections with a numbering system. Update trail map brochures with trail intersection numbering system, and provide brochures for trail users. Orientation wayside signs $\left(3^{\prime} X 5^{\prime}\right)$ should be considered for priority trailhead locations.

- The northern portion of region 4 can provide good conditions for dog sled training. The regional trails committee suggests that dog sledders may use ATVs to train dog teams after obtaining a Special Use Permit and provided that the motor will not be used for vehicle propulsion.

- Visitor trail use patterns, site location and suitability, point to Wendell state Forest as an ideal location to establish a nordic ski touring center. The closest opportunity for this type of formal nordic skiing is in Northfield, where the popular ski touring center associated with the Northfield Mountain Recreation Center is often inundated with use. Wendell state Forest would be closer to population centers, and due to higher elevation, the snow conditions would be slightly better. To support the nordic ski use, the flatter area around Ruggles Pond could be reserved for skiers, while snowmobilers and skiers would be permitted throughout the remaining majority of the trail system. A ski touring center could be developed as a public-private partnership. There is potential to establish a concession area at an off-road parking site along Montague Road.

- Warwick State Forest - Mount Grace Land Conservation Trust

- Establish trail connections between DEM and MGLCT properties. where feasible. Prior to establishing additional hiking trails, supply and demand for this type of trail mileage should be surveyed.

- Work with the local snowmobile club to extend snowmobile trails into the new 108-acre property that was acquired in fee by DEM.

- Construct bollards or gates in key locations to restrict ORV and 4 WD access.

- Develop trailhead signs indicating the cooperative nature of the newly acquired conservation properties. Trailhead signs should include a list of invited uses. MGLCT signs will not list hunting as an invited use. Trail signs can be standardized with new carsonite markers. 
- Ware River Rail Trail (WRRT)

- Promote implementation of WRRT improvement project.

Phase I - Feasibility study, with input from citizen advisory committee, to make recommendations for trail surface, multi-use orientation, \& investigate problem areas.

Recommendations of the north-Quabbin GOALS Trails

Committee:

- This rail trail does not connect population centers and therefore should not have an alternative transportation focus. It is a very important recreation resource for this region and should be available for snowmobilers, hikers, $\mathrm{x}$-country skiers, horseback riders, mountain bikers.

- The surface should be a non-paved, porous, compactible material such as stone dust.

- Burnshirt River bridge needs safety improvements, including chain link fence along the sides, and measures to prevent access by 4-WD vehicles.

Phase II- Design

(Including Route 2 double tunnel).

Phase II Construction.

(Phases II \& III should also be emphasized in the capital recommendations section of the GOALS plan, approximate cost of double tunnel is one-half to one million dollars)

Assess possibilities for acquisition of New England Power / $B \& M$ railroad ROW extending northward from the end of the Ware River Rail Trail. This includes a crossing of the Otter River where steel beams and decking would be required.

Note: Work activities on portions of the trail are subject to the Wetlands Protection Act, including the new 200-foot stream and river buffer resource area, and will only be conducted following local Conservation Commission and DEP review. Within MDC Watershed Districts, work is also subject to review under Watershed Protection Act regulations 350 CMR 11.00, administered by MDC Division of Watershed Management.

- Potential long-distance trail network (Figure 4).

- Utilize protected open space and unimproved town and county roads wherever possible. Focus on establishing east - west trail connections. Prioritize possible connections with old unimproved roads. Attempt to contact towns related to these specific roads, with information on options to discontinue, while maintaining public access. 
- Emphasize benefits for municipalities by promoting methods for alleviating town maintenance responsibility and liability for unimproved roads, while maintaining the roads as public rights-of-way.

- Work with MHD and Town of Northfield related to options and possible funding sources for widening a sidewalk / shoulder for both warm and cold weather use on the Route 10 bridge to allow trail connections across the connecticut River. Also, work toward legal access for snowmobiles across the French King Bridge.

- Monitor for Route 2 safety upgrade initiatives in the Erving area. This type of project might be used as an opportunity to improve trail connections between wendell and Erving state Forests, and to improve continuity of the Metacomet-Monadnock Trail.

- Contact landowners related to permission to access large private ownership parcels in order to establish linkages in a potential trail network.

- Establish spur connections to Mid-state Trail, MetacometMonadnock Trail, Athol - Orange Greenway, Ware River Rail Trail, and town centers wherever possible.

- Provide advisory support for the North Central Pathway project in Gardner \& Winchendon. This path will link the downtown Heritage state Park visitor center with Dunn Pond, and will be compatible with the Universal Access facilities. Also, the winchendon end of the trail will provide the potential to link with the Ware River Rail Trail and otter River state Forest.

- Potential long-distance trail routes must be thoroughly field checked related to permission to access private, municipal or nonprofit land, and for sensitive resources that could make areas unsuitable for trail use.

- The establishment of long-distance trails that include a variety of ownerships will require a lead-off study phase to determine suitable routes, and an organizing group to direct communications, volunteer etorts, \& implementation. The Conway School of Design (CSD) has expressed interest in undertaking the study phase as one of their school projects. DEM should remind CSD and promote this as a viable and interesting project. The organizing group might be formed from a combination of DEM staff, interested members from the GOALS trails committee, and members from the following groups:

Franklin County Commission trails planning project, Franklin County Bikeway, Millers River Watershed Council, North Central Pathway in Gardner and Winchendon, Millers River Greenway Committee, MDC-Quabbin Recreation Plan Committee, Statewide Greenways \& Trails Plan, Mount Grace Land Conservation Trust, Army Corps of Engineers, \& towns.

- Enhance trail accessibility contingent on limiting site factors, following guidelines of the Americans with Disabilities Act. Bring interested individuals into a public decision process whenever new trails are being considered. 
- Trail maintenance \& volunteer coordination.

- Plan and implement small volunteer maintenance and construction projects to bring together the different user groups.

- Provide guides for trail etiquette on multiple use trails and for construction and maintenance that include the needs of various trail users to promote cooperation by helping user groups learn more about each other.

- Promote formation of advisory committees / friends groups for these forests \& parks.

- Provide support for trail interest groups (see Appendix H).

- Promote the excellent trail opportunities and scenic / interesting stops along trails with marketing options listed in the recommendations of this plan's Recreation section. Develop links between Bed \& Breakfasts and the regional trail system (Figure 6).

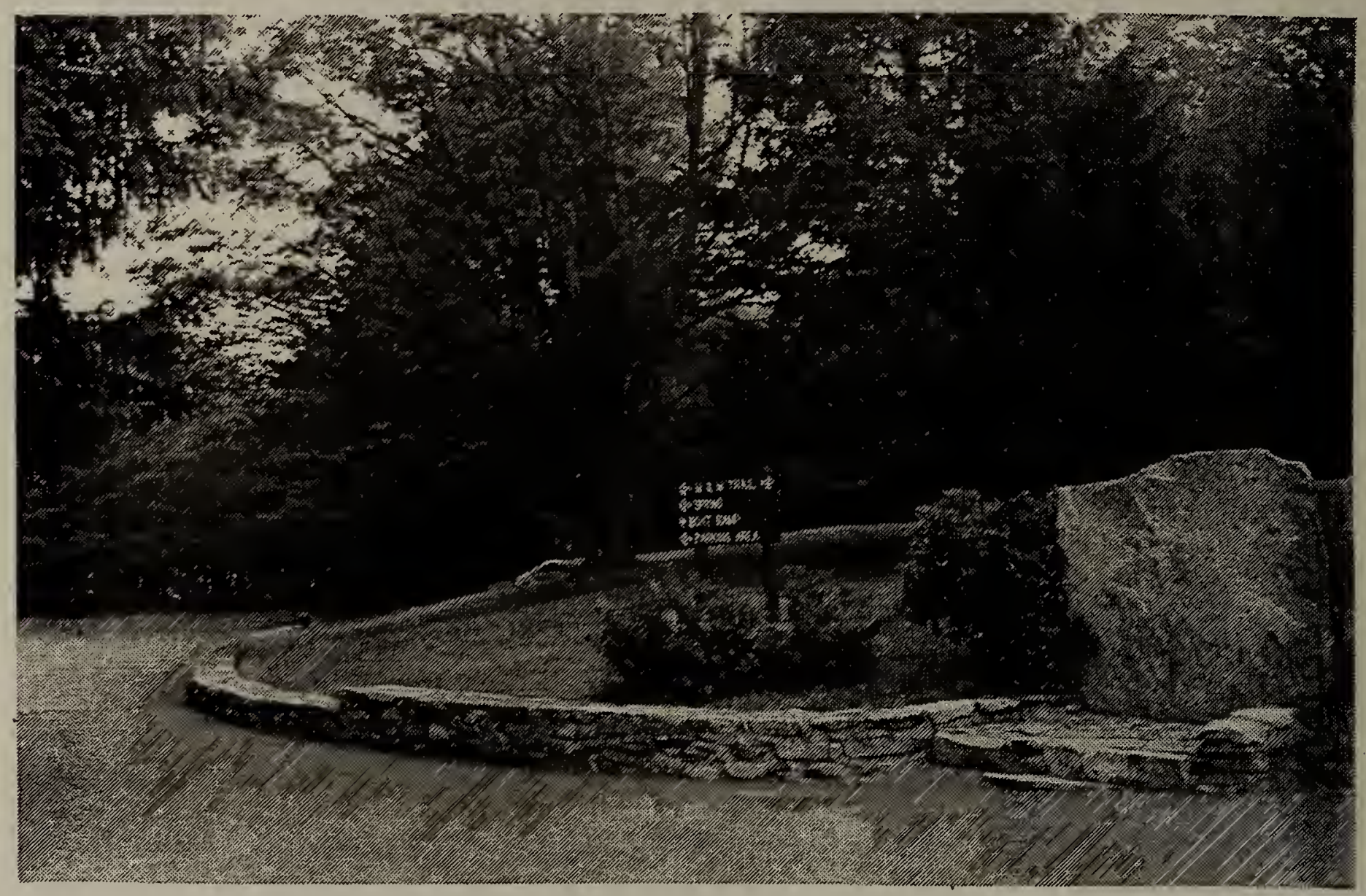

Access to the Metacomet-Monadnock Trail in Wendell state Forest. 


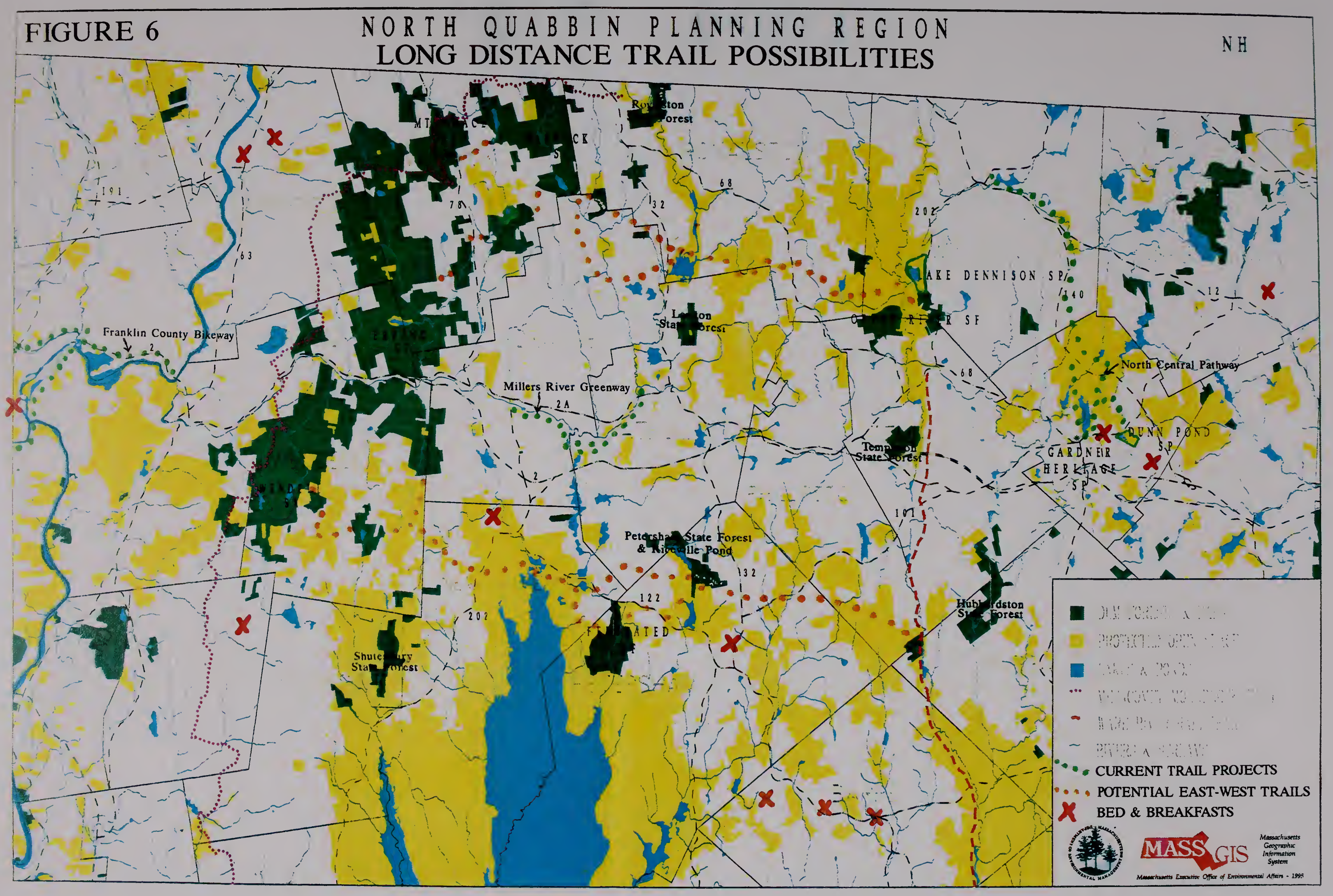


Bed \& Breakfasts and Country Inns shown on the regional trail map.

Ashburnham:

- John Adams Homestead. 287 Russell Hill Rd. (508) 827-5388.

Barre:

- The Old Jenkins House. 7 West St. (508) 355-6444.

- Harding Allen Estate. Route 122. (508) 355-4920.

- Hartman's Herb Farm B\&B. Old Dana Rd. (508) 355-2015.

Gardner :

- Hawke B\&B. 162 Pearl St. (508) 632-5909.

- Colonial B\&B. Betty Spring Rd. (508) 630-2500.

Greenfield:

- Brandt House. 29 Highland Ave. (413) 774-3329.

Leverett :

- Hannah Dudley House. 114 Dudleyville Rd. (413) 367-2323.

Northfield:

- Northfield Country House B\&B. School st. (413) 498-2692.

- Centennial House B\&B. 94 Main St. (413) 498-5921.

North New Salem:

- Bullard Farm B\&B. 89 Elm St. (508) 544-6959.

Petersham:

- Winterwood at Petersham. North Main St. (508) 724-8885. 


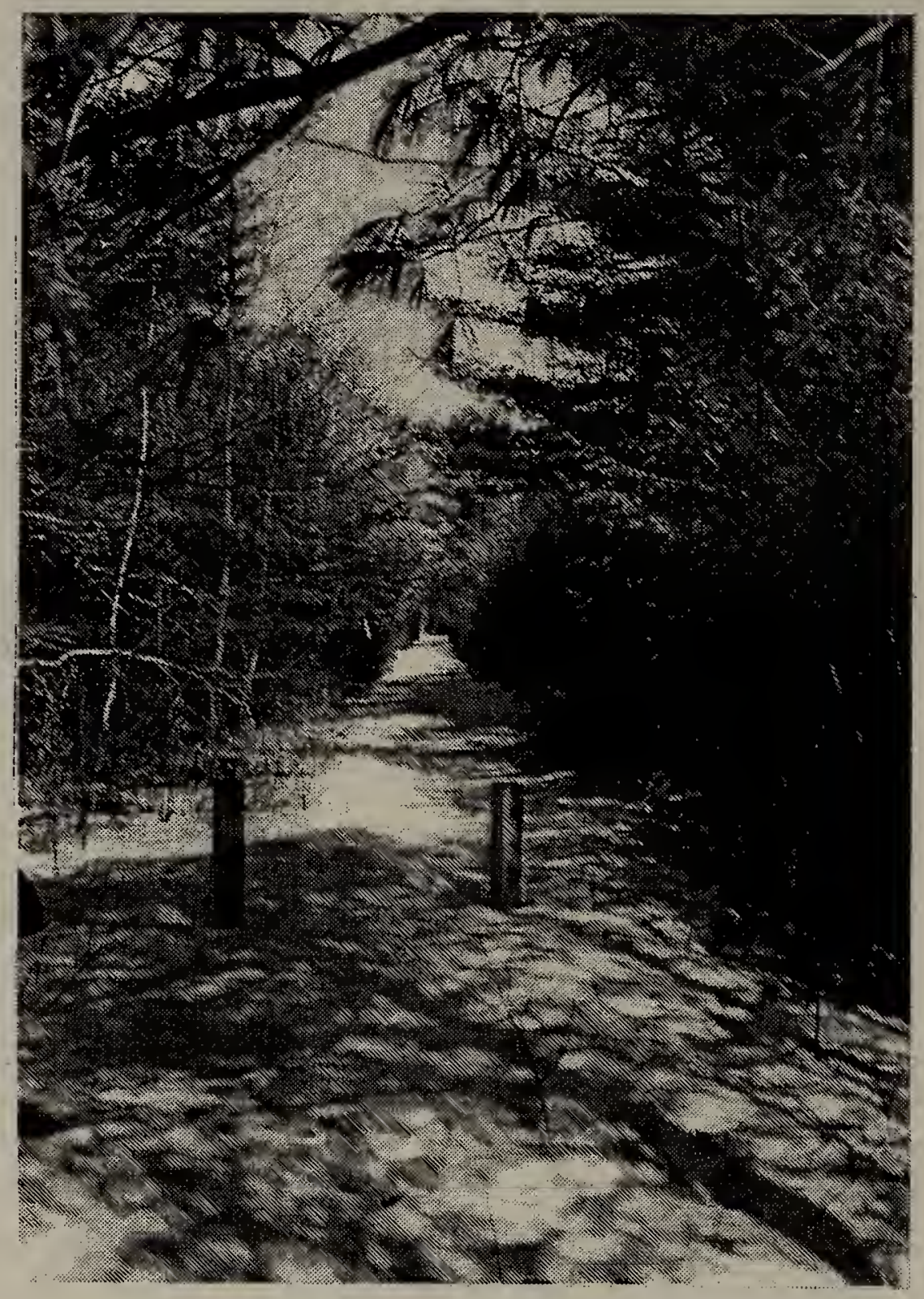

Ware River Rail Trail in Barre. 


\section{STAFF ORGANIZATION}

One of the most important reasons for studying a cluster of several parks as a single management unit, is to be able to develop strategies for staff coverage and for shared use of equipment and vehicles that will promote the most efficient delivery of visitor services and management of park resources on a regional basis.

\section{STAFFING KEY}

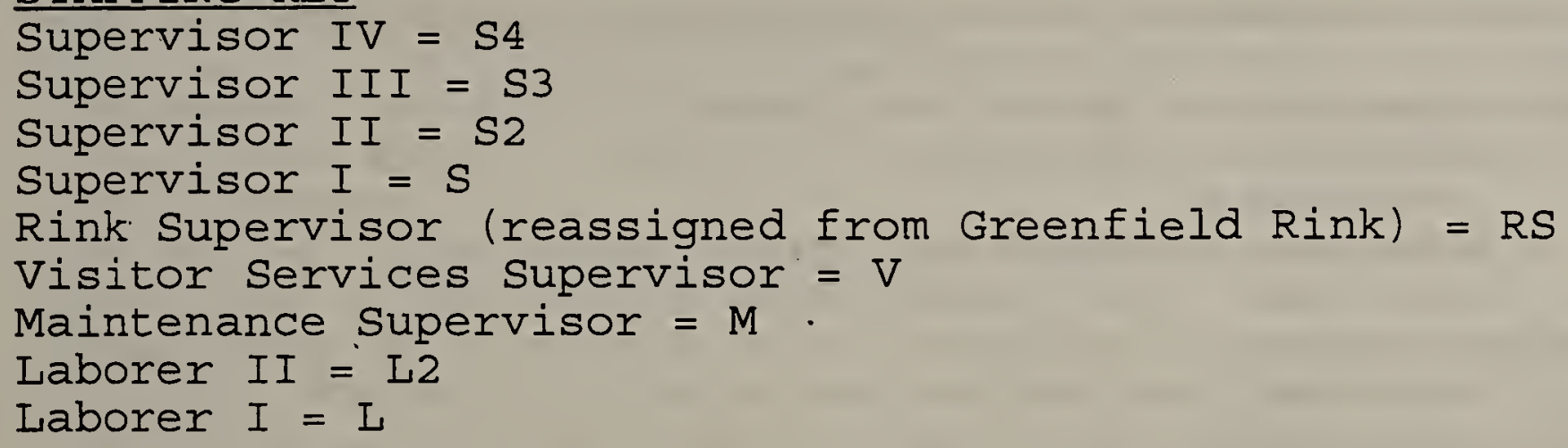

[Seasonal Positions]

Supervisor $=[\mathrm{S}]$

Laborer $=[\mathrm{L}]$

Interpreter $=[I]$

Lifeguard $=[\mathrm{G}]$

Summer Worker $=[\mathrm{W}]$

$\mathrm{Clerk}=[\mathrm{C}]$

\section{CURRENT FY 96 STAFF POSITION ASSIGNMENTS}

Otter River / Lake Denn:

$$
\begin{array}{r}
\text { Year-round - S4, S2, L2, L2, L, L } \\
\text { Long-term seasonal } \\
\text { Otter Riv - [S], 3[L] } \\
\text { Lake Denn - } 2[\mathrm{~S}], 7[\mathrm{~L}],[\mathrm{C}] \\
\text { Short-term seasonal } \\
\text { Otter Riv - } 3[\mathrm{G}], 2[\mathrm{~W}] \\
\text { Lake Denn - [I], } 4[\mathrm{G}], 6[\mathrm{~W}]
\end{array}
$$

Gardner Heritage:

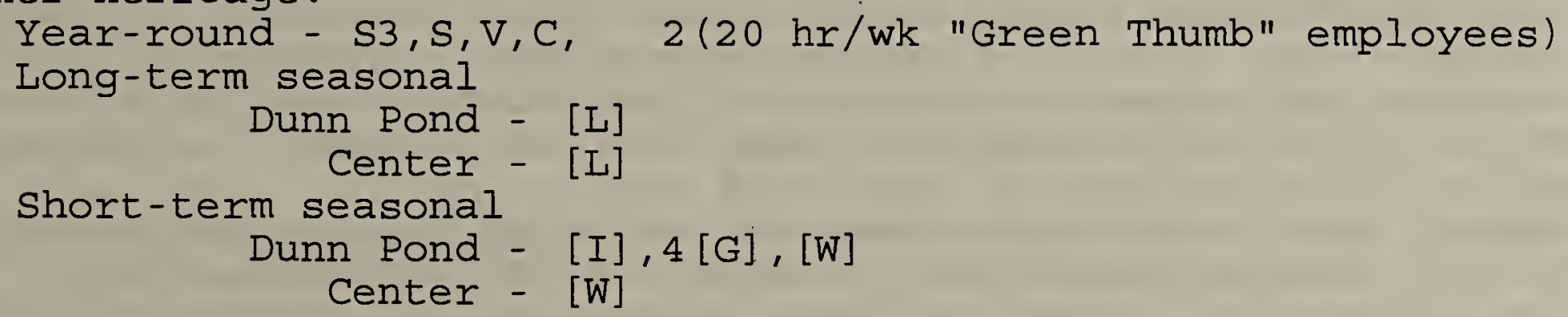

Erving:

Year-round - S3, RS, L2, L Long-term seasonal - $3[\mathrm{~L}]$

Short-term seasonal - $5[\mathrm{G}],[\mathrm{W}]$
Wendell:

Year-round - S2, L, L

Short-term seas. - $2[\mathrm{G}]$ 
RECOMMENDED ORGANIZATION WITH CURRENT STAFFING LEVEL

$\begin{array}{lll}\text { Otter River / Lake Denn } & \text { Summer } & \text { Winter (Oct. - April) } \\ \text { \& Federated: } & \mathrm{S} 4, \mathrm{~S} 2, \mathrm{~L} 2, \mathrm{~L} 2, \mathrm{~L}, \mathrm{~L} & \mathrm{~S} 4, \mathrm{~S} 2, \mathrm{~S} 2, \mathrm{RS}, \mathrm{L} 2, \mathrm{~L} 2, \mathrm{~L}, \mathrm{~L} \\ \text { Gardner Heritage: } & \mathrm{S} 3, \mathrm{~S}, \mathrm{~V}, \mathrm{~L}, \mathrm{C} & \mathrm{S} 3, \mathrm{~S}, \mathrm{~V}, \mathrm{~L}, \mathrm{C} \\ \text { Erving: } & \mathrm{S} 3, \mathrm{RS}, \mathrm{L} 2, \mathrm{~L} & \mathrm{~S} 3, \mathrm{~L} 2, \mathrm{~L}, \mathrm{~L} \text { (includes } \\ \text { Wendell: } & \mathrm{S} 2, \mathrm{~L} & \text { coverage for Wendell } \\ \text { Mt Grace: } & & \text { and Mt. Grace) }\end{array}$

Summer seasonal assignments as indicated above in current FY 96 organization.

Long-term seasonal:

Otter Riv - [S],3 [L]

(Federated)

Lake Denn - $2[\mathrm{~S}], 7[\mathrm{~L}],[\mathrm{C}]$

Dunn Pond - [L]

Gardner Center - [L]

Short-term seasonal:

Erving - 3 [L]

Otter Riv - $3[\mathrm{G}], 2[\mathrm{~W}]$

(Federated)

Lake Denn - [I], $4[\mathrm{G}], 6[\mathrm{~W}]$

Dunn Pond - $[\mathrm{I}], 4[\mathrm{G}],[\mathrm{W}]$

Gardner Center - [W]

Erving - 5[G], [W]

Wendel.1 - 2 [G]

This cluster of parks is being studied as a single management

'unit in order to improve the effectiveness of staff coverage, and shared use of vehicles and equipment. The new cluster

organization will be more apparent in the winter with otter River as the headquarters of the cluster. Erving and Gardner Heritage will be important satellites due to the significance of winter recreation and programs, with Erving covering the western end of the cluster.

Crews for specific work projects will be organzied out of otter River during the winter. Work projects will be conducted throughout the cluster as needed and will include road grading, trail grooming/marking/rerouting/closing/new construction, boundary work, structural rehab such as roof reshingling, snow plowing, picnic table construction, additional coverage for special events that generate large visitor attendance such as ice skating with bonfires at Dunn Pond and for special needs such as carpool travel assistance when DEM vehicles require professional service station maintenance, cleanup of illegal dump sites.

At the beginning of the winter staffing time period, priorities and timetable for work projects will be developed by the Regional \& Assistant Regional F\&P Director in coordination with cluster park supervisors. Priorities and work schedule will be updated at the monthly F\&P Regional staff meeting or as needed. 
The following recommendations were developed to improve public safety and recreation services, and strengthen DEM's ability to protect valuable natural and cultural resources in the most effective manner possible, with a minimum of additional staff.

Addition of 2 Year-round Laborers as floating positions for the east end of the cluster (Otter River \& satellites/Gardner

Heritage), and

Addition of 2 Year-round Laborers as floating positions for the west end of the cluster (Erving/Wendell/Warwick) would allow:

- Increased ability to grade park. roads on a regular basis.

- Increased ability related to trail grooming and other trail maintenance.

- Strengthen productivtiy and increase scheduling flexibilitiy of proposed winter period work crews.

- The staff in this portion of Region 4 constructs picnic tables for DEM forests and parks statewide, and provides signs for all of Region 4. This work is mostly accomplished in the winter. An additional Laborer position during the winter would benefit these regional and statewide projects.

- Increased provision of recreation services such as preparation for earlier opening and later closing for campgrounds, reopening the $\mathrm{Mt}$. Grace field as a picnic area or reopening the toboggan - sliding hill, improved maintenance and availability of camping sites at Federated state Forest.

Addition of year-round laborer for Dunn Pond SP to cover additional maintentance responsibilities associated with the new universal access facilities.

Convert seasonal clerk to year-round position to cover campground reservations for Lake Dennison and Otter River, and to assist with other work for the cluster.

Addition of 2 seasonal positions, summer workers or laborers, for each park that offers camping services would allow for overnight contact station coverage. ( 2 for Beaman/Dennison, 2 for Erving)

Otter River currently uses the services of the seasonal Park Interpreter assigned to Lake Dennison, but level of use justifies two separate seasonal Interpreter positions.

Seasonal Park Interpreters should also be considered for Erving and Wendell if additional positions become available.

Addition of seasonal laborer for coverage of Mt Grace. Mt Grace is a locally important recreation area, which can not be adequately covered at the current staffing level. This would be an important step towards providing visitor services during the summer recreation season.

Regional funding for priority boundary survey contracts, including blazing newly acquired lands. 


\section{PARK RANGERS}

The Park Ranger Program, which was initiated in 1983, is administered within DEM's Division of Forests \& Parks. The program has the responsibilities of enforcing DEM rules and regulations within the state forests \& parks, searching for lost or missing persons, and assisting the Bureau of Fire Control when needed. In addition, the rangers are responsible for providing educational programs and numerous visitor services such as first aid and technical user information.

There are no full time Park Rangers in DEM, but the commitment to law enforcement is fulfilled by 35 park supervisors who have been trained to be Park Rangers. The training focuses on compliance through education as a first step on the enforcement ladder, rather than the more traditional enforcement measures taught to law enforcement officers. Only after the educational process has failed, do park rangers begin to use their law enforcement training and invoke the non-criminal citation process. The Park Rangers who work out of the forests \& parks in the Connecticut River Valley and Central Massachusetts, will combine their efforts whenever possible to enhance the educational and enforcement presence in this region.

The primary issues that need to be dealt with by DEM's Park Rangers are campground and day use patrols, bike trail patrols and ORV patrols. In addition, the ever expanding winter usage of DEM facilities has created a demand for winter patrols which include nordic skiing and snowmobile patrols. Park Rangers also provide support and education at Department events and hearings.

In the parks represented by this GOALS plan there are two park rangers authorized to perform these functions. Each supervisor enforces rules and regulations at their assigned forests \& parks as they carry out their regular duties. In addition, whenever possible, they patrol other sites to provide an enforcement presence in areas with specific problems, particularly related to restrictions on the use of ORVs in these parks.

The immediate future of the Park Ranger Program for these parks will include the training of additional staff to enforce rules and requlations, and the placement of seasonal park rangers to support the supervisors efforts. However, the year-round activity in this area of the state supports the presence of two full time park rangers to provide programming, visitor services and enforcement required to protect the resources and the visitors. 


\section{CAPITAL REHABILITATION \& IMPROVEMENTS CATEGORIZED BY PARK}

The listing of vehicle and equipment, and road grading recommendations at the beginning of this section is intended to emphasize the importance of these regional priorities.

\section{VEHICLES \& EOUIPMENT}

West end of cluster (Erving/Warwick/Wendell):

- Rack truck with snow plow

- Large tractor with all attachments

- Small vehicle (golf cart size) for comfort station maintenance

East end of cluster (Otter River \& satellites/Gardner Heritage):

- Light truck with plow for GHSP

- Large tractor with all attachments

- Small vehicle (golf cart size) for Dunn Pond universal access trail maintenance

- New industrial grade planer for sign construction ( $\$ 4.5 \mathrm{~K}$ estimate)

To make inter-park shared use of equipment and vehicles more effective, a log book with vehicle use and maintenance information should be kept with equipment on loan. Also, sublet of equipment should be reported to the area supervisor prior to use elsewhere in the cluster or region.

Grading of park roads on a regular basis to ensure adequate access related to public safety and resource management is a priority of Forest \& Park and Bureau of Forest Development staff. - Establish dedicated funding for road grading materials from local gravel operations.

$$
.3
$$

The criteria used to establish capital rehabilitation and improvement priorities are health and safety of visitors, enhancement of visitor services and environmental protection, including upgrades to comply with the Americans with Disabilities Act and Title $V$ requirements. Cost estimates are provided in the second Rehabilitation \& Improvement section, which is categorized by type of project.

\section{OTTER RIVER}

Priority Level

- Replace remaining vault toilet.

- Filters for Beaman Area comfort stations w/ flush automatics, also showers and ADA upgrades.

- Rehab bathhouse - install 200 amp service, ADA upgrades.

- Beaman Pond dam gate valve replacement.

- Dam surfacing repair. 
- Testing and removal of asbestos and underground Priority Level fuel tank.

- Upgrade transite pipes in water system.

- Headquarters, main garage \& back garage rehab.

- Contact station sills, wiring, chimney, roof.

- Resurface road from federal gate to end of pavement $(0.5 \mathrm{mile})$.

- Resurface headquarters parking area.

1

2

2

1

- Regrade gravel roads.

- Install two gates - wood shed area and ball field.

- Trails - rebuild foot bridges, Wilder McKensie Trail maintenance.

- Install permanent site markers in camping area.

- Beaman Pond water quality - watershed management action plan.

\section{LARE DENNISON}

- Comfort stations upgrade

- Replace beach area bathhouse.

- Accessibility rehab for one comfort station in North Area and one comfort station in East Area.

- Replace showers - two buildings in North Area and one building in East Area.

- Rehab East Area structures - glass to one-half inch plexiglass.

- Upgrade (slip lining) for transite pipes in . I water system.

- Construct two small contact stations for Upper 2 Picnic Area.

- Resurface entrance road from Rt 202 to boat ramp 2 (1.1 miles).

- Resurface day use parking lot.

- Relocate or rehab gravel roads that are flooded in the spring.

- Rehab North Area roads - root damage, shoulder repair.

- Install "Caution - Curve" signs at New Boston Rd intersection.

- Install new fencing at Upper Picnic Area, Beach Area and North Camping Area.

- Install single strand guardrail from boat ramp in both directions (2000 to 2500 feet total).

- Install bike racks in all areas ( 5 racks total).

- ACOE required lakeshore erosion study / action plan. 2

Note: ACOE - Real Estate Division should be informed in writing of rehab. and improvement projects proposed for Lake Dennison. Under the terms of the 50-year lease, ACOE is entitled to review DEM plans. 
- Reclaim entrance road (3 miles). 1

- Install gate.

\section{WARE RIVER RAIL TRAIL}

- Design contract phase.

- Install gates. 2

- Regrade - multi-use surfacing, drainage 2 improvements.

- Bridge rehab.

- Route 2 underpass tunnel.

GARDNER HERITAGE V.C.

- Painting exterior

- Acquisition / conversion of abutting structure for garage \& storage.

\section{DUNN POND}

- Universal access project completion. 1

- Remove brush and trees from earthen dam. ' 1

- Bury existing electrical service from the street 2 to the pond house.

- Plant young pine trees in pine grove picnic area. 2

- Title of stump Pond parcel transferred from City . 2 to DEM.

\section{ERVING}

- Leach field for day use comfort station. Work must be conducted prior to repaving road.

- Resurface Laurel Lake Rd (3 miles).

- Campground comfort station, power line \& removal of vault toilet.

- Headquarters septic \& removal of shallow 1 injection well.

- Landfill capping.

- Install iron gates in the following locations:

- entrance to camping area, 110 feet from brook,

- entrance to beach area to replace wooden gate,

- entrance to Moss Brook Rd to replace wooden gate,

- entrance to North Rd to replace wooden gate.

- Install fencing barrier along Laurel Lake Rd 2

- (by fire pond).

- Laurel Lake dam gate system rehab. (see Appendix I.) 2 for detailed recommendations)

- Install permanent site markers for campground 2 (new trail marker material).

- Headquarters structural rehab.

- Resurface headquarters parking area.

Laurel Lake pH management - establish dedicated fund for lime applications. 
Headquarters septic.

- Parking area and recreational field rehab. 2

- Headquarters rehab - heating system and . 2 security system.

- Gravel road grading and gates.

\section{WARWICR}

- Security fencing with gate.

- Security system for building.

- Resurface parking area.

- Gravel road grading and gates.

- Sheomet Lake dam rehab. (see Appendix I for detailed recommendations)

- Richards Reservoir dam rehab. (see Appendix I)

- Recreation demand analysis and possible design for swimming area development at sheomet Lake.

\section{WENDELL}

- Road rehab. - extensive repairs needed due to severe 1996 storm damage.

- Clivus composting toilets (2) for Ruggles day use area.

- Design for dam sluiceway rehab.

- Ruggles Pond water quality improvement action plan.

- Picnic area well rehab - uncap, pump, test, 2 replace hand pump.

- Headquarters toilet ADA upgrade.

\section{MEM TRAIL}

- Trail maintenace (ongoing) and construction of shelters. 
Potential Long-range Recreation Improvements

- Lake Wyola acquisition and swimming area development.

- Erving campground expansion - 22 family sites, and a group site.

- Wendeli cabin/yurt development.

- Wendell nordic ski center development.

- Lake Dennison upper picnic area expansion and comfort station.

- Ruggles Pond swimming area upgrade.

- Sheomet Lake swimming area development.

- Lake Dennison group camping area and comfort station.

- Erving - expansion of parking area for boat ramp.

- Determine best location at the western end of the cluster for playground facilities (eastern end has facilities at Dunn Pond).

An annual or semi-annual working session with the Regional Forest \& Park staff, Regional Engineer and Regional Planner should be held to develop and update rehab and improvement priorities, with the intention of coordinating GOALS plan and 5-year Capital plan recommendations for improved implementation.

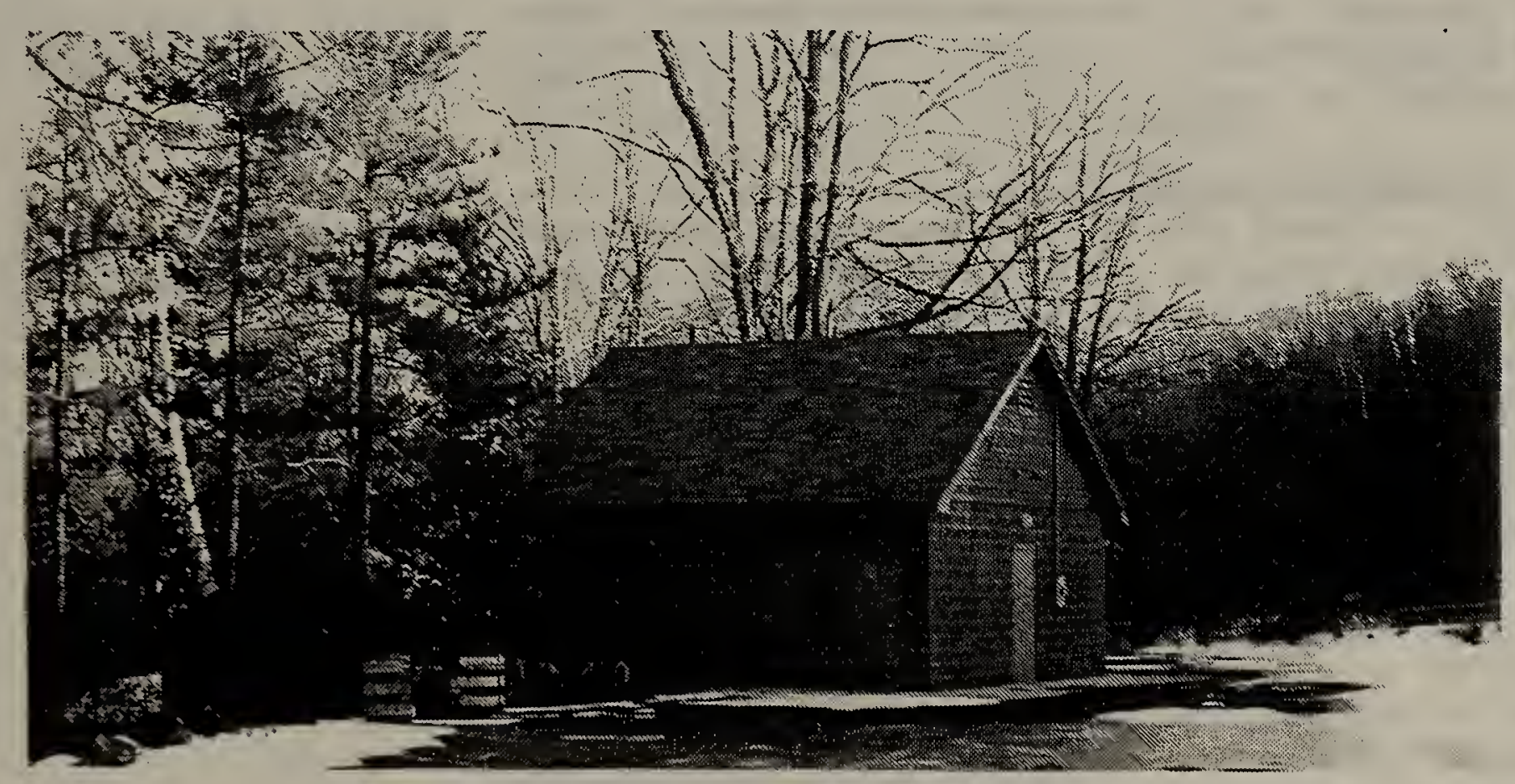

New comfort station in Erving state Forest. 


\section{CAPITAL REHABILITATION \& IMPROVEMENTS CATEGORIZED BY TYPE OF PROJECT}

The cost estimates included in this section are for 1996. Estimates will appear after specific rehabilitation or improvement items in the following format: $(18 \mathrm{~K})=\$ 18,000$

VEHICLES \& EOUIPMENT

West end of cluster (Erving/Warwick/Wendell):

- Rack truck with snow plow

- Large tractor with all attachments

- Small vehicle (golf cart size) for comfort station maintenance

East end of cluster (Otter River \& satellites/Gardner Heritage):

- Light truck with plow for GHSP

- Large tractor with all attachments

- Small vehicle (golf cart size) for Dunn Pond universal access trail maintenance

- New industrial grade planer for sign construction ( $\$ 4.5 \mathrm{~K}$ estimate)

To make inter-park shared use of equipment and vehicles more effective, a log book with vehicle use and maintenance information should be kept with equipment on loan. Also, sublet of equipment should be reported to the area supervisor prior to use elsewhere in the cluster or region.

ROADS \& PARKING AREAS

- Wendell - Road rehab. - extensive repairs needed due to severe 1996 storm damage. (452K - cost breakdown is included on the following page.)

- Establish dedicated funding for road grading materials from local gravel operations.

- Erving - Resurface Laurel Lake Rd - 3 miles. (150K)

- Lake Dennison - Resurface entrance road from Rt 202 to boat ramp - 1.1 miles. (100K)

- Lake Dennison - Resurface day use parking lot. (75K).

- Otter River - Resurface road from federal gate to end of pavement - 0.5 mile. (50K)

- Otter River - Resurface headquarters parking area. (50K)

- Erving - Resurface headquarters parking area. (150K)

- Federated - Reclaim entrance road - 3 miles. (150K)

- Lake Dennison \& Birch Hill - Relocate or rehab gravel roads that are flooded in the spring. (200K)

- Lake Dennison - Rehab North Area roads - root damage, shoulder repair. (150K)

- Otter River - Regrade gravel roads. (100K)

- Mt Grace - Parking area. (25K)

- Mt Grace - Gravel road grading. (25K)

- Warwick - Resurface parking area. (40K)

- Warwick - Gravel road grading (35K) and gates (15K). 


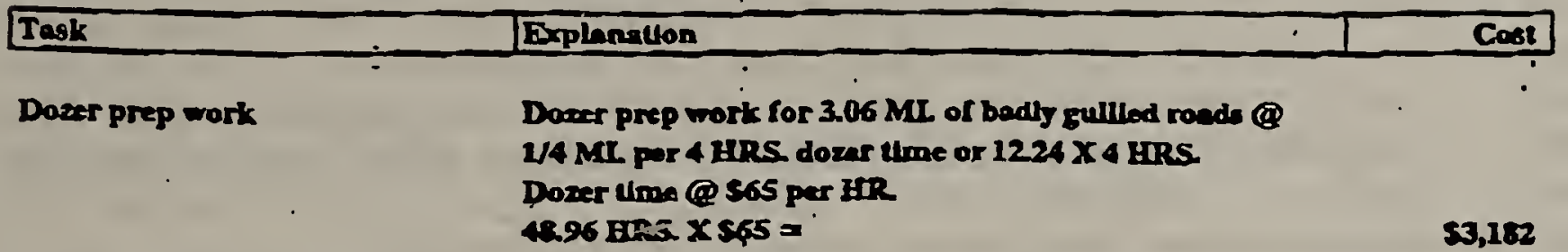

Backboe ditch \& drain work

Graved (Dellvered)

Gravel (Spreadlog)

Culven malertals

Culvert Installacton

BBD construction
24.42 ML or 128.937.6 FT, of work required. (Q) 200 FT. per 8 ERS machine time. 223,937.6 R/ $/ 800 \mathrm{r}$ par dipg = $161.17 \mathrm{dogs}$ of bockbou work

8 ERS wachine 1100 X $\$ \$ 45$ per BR $=\$ 360$ per ding. Dilch work requlred extimaled by abservation durine rond survay

161.17 days $\times 3360=$

RR/CR 3L,633 CU. YDS, X $\$ 5.50$ per CU. YD. PG/SG 12,506 CU. YDS. X\$8.00 per CU. YD.

$\$ 175,084$ S200,051

BIUCR 31,833 CU. YDS. + PG/SG 12,505 CU. YDS. $=44,339$ CU. YDS divlded by 16 CU. YDS. per land

- 2,771 loads @ $16 \mathrm{cu}$ yards par load.

25 br. dower epreadling elme per load for a lold or $6927 \mathrm{hbz}$ doser .25 HRS $\times 2,771$ lads = $6927 \mathrm{hr}$ muchine t/mo 629.7 ERS. $8 \$ 63$ per GR $=$

NEW ADS (IINESD) NEEDED

ADS 15" X 36 FCS @ $\$ 99.00$ per culvert =

ADS $18^{*} \times 9$ PCS. $\$ \$ 237.80$ per culver $=$

51,240

ADS 36" X 1 PCS @ 5465.10 per entver =

5465

RRPLACEMTENT ADS (WTVED) CULVERTS NETTDED

100\% failed eulverts totaled 70 PLPES, escrumptlan

ASSUMIPIION: $1 / 2$ of $100 \%$ falled culverts will need to be replace with ADS (lined) $15^{\prime}$ culvert:

$1 / 2$ rumber of falled culverts $=35$

ADS $15^{\prime} \times 35$ FCS. @ $\$ 98.00$ per culver =

$\$ 2,630$

\section{PIR PIPE}

26 AlRs. beckbon @ $\$ 45$ per FIR $=\$ 117.00$

2 inbores@ @ 52250 per man hour HR.

for 26 hours par plpe to rebuild headers

(4) 5117 per pipe bualled

monchio elime $(\$ 117)+$ labor $(\$ 117)=\$ 234$ per plpe

$\$ 1$ cuiverts X $\$ 234$ per culven installation $=$

MACETNE TIME

363 BED's (Broed base dips) needed

Q rato of 3 BBD's per HR

363 BBD's devided by 3 per HR = 121 HRS.

machline time

121 HRRS, X 565 per HR =

MATERIALS

PG/SG $=12 \mathrm{CU}$. XD. per BED

12 CU. YD. X 363 BBD's 4,356 CU. YD.

$4,356 \mathrm{CU} \times \mathrm{YD} . \times \$ 8.00 \mathrm{CU} . \mathrm{YD}=$

TOTAL for $28.67 \mathrm{MI}$. of stale lorest roads $>>>>>$ 
- Lake Dennison - Comfort stations upgrade. (500K)

- Erving - Leach field for day use comfort station. Work must be conducted prior to repaving road. (150K)

- Wendell - Replace vault toilets with Clivus composters. (22K)

- Erving - Campground comfort station, power line and removal of vault toilet. (175K)

- Erving headquarters septic \& removal of shallow injection well. (100K)

- Otter River - Replace remaining vault toilet. (100K)

- Otter River - Filters for Beaman Area comfort stations w/ flush automatics, also showers and ADA upgrades. (15K)

- Mt. Grace headquarters septic (15K)

\section{WATER SYSTEM UPGRADES}

- Wendell - Picnic area well rehab - uncap, pump, test, replace hand pump. (8K)

- Lake Dennison - Upgrade (slip lining) for transite pipes in water system. (100K)

- Otter River - Upgrade for transite pipes in water system. (100K)

\section{STRUCTURAL REHAB}

- Lake Dennison - Accessibility rehab for one comfort station in North Area and one comfort station in East Area. (20K)

- Otter River - Rehab bathhouse - install 200 amp service, ADA upgrades. (10K)

- Wendell - Headquarters toilet ADA upgrade. (10K)

- Gardner Heritage V.C. - Painting exterior. (8K)

- Erving - Headquarters structural rehab. (125K)

- Otter River - Headquarters, main garage \& back garage structural rehab. (75K)

- Lake Dennison - Rehab East Area structures glass to one-half inch plexiglass. (10K)

- Otter River - Contact station sills, wiring, chimney and roof. (25K)

- Mt Grace - Headquarters rehab - heating system and security system. (1K)

- Warwick - Security system for building. (1K)

- Birch Hill - Rehab office roof. (7K)

\section{RECREATION FACILITY SUPPORT}

- Erving landfill capping. (1,000K +)

- Boundary surveys.

- Otter River - Testing and removal of asbestos and underground fuel tank. (Clean Harbors funding)

- Erving - Install fencing barrier along Laurel Lake Rd (by fire pond). (3K)

- Lake Dennison - Install "Caution - Curve" signs at New Boston Rd intersection. (OK)

- Lake Dennison - Install new fencing at Upper Picnic Area, Beach Area and North Camping Area. (25K)

- Lake Dennison - Install single strand guardrail from boat ramp in both directions (2000 to 2500 feet total). (20K) 
- Lake Dennison - Install bike racks in all areas, 5 racks total. (7K)

- Erving - Install metal gates in the following locations:

- entrance to camping area, 110 feet from brook,

- entrance to beach area to replace wooden gate,

- entrance to Moss Brook Rd to replace wooden gate,

- entrance to North Rd to replace wooden gate.

(5K per gate if fabrication and installation is required.)

- Otter River - Install two gates - wood shed area and

ball field.

- Wendell - Install gates.

- Federated - Install gate.

- Mt Grace - Install gates.

- Warwick - Security fencing with gate. (7.5K)

- Dunn Pond - Plant young pine trees in picnic area. (oK)

- Erving - Install permanent site markers for campground (new trail marker material). (OK)

- Otter River - Install permanent site markers in camping area. (OK)

- Dunn Pond - Completion of universal access improvements.

- Dunn Pond - Bury existing electrical service from the street to the pond house. (110K)

- Mt Grace - Recreational field rehab. (OK)

- All parks should consider 3' X 5' "Welcome to..." orientation wayside sigṇs for all main buildings. (5K)

\section{TRAILS}

- Otter River - Rebuild foot bridges, Wilder McKensie

Trail maintenance. (OK)

- Ware River Rail Trail (WRRT) - Design contract phase. (400K)

- WRRT - Install gates.

- WRRT - Regrade - multi-use surfacing, drainage improvements.

- WRRT - Bridge rehab.

- WRRT - Route 2 underpass tunnel.

- Metacomet - Monadnock Trail - Trail maintenace (ongoing) and construction of shelters. (OK)

- All parks - installation of short, self-guided interpretive trails, and orientation wayside signs for priority trailhead locations. (10K).

\section{LAKE \& POND MANAGEMENT}

- Lake Dennison - ACOE required lakeshore erosion study and action plan. (OK)

- Dunn Pond - Remove brush and trees from earthen dam. (OK)

- Wendell - Ruggles Pond water quality improvement action plan. (400K)

- Erving - Laurel Lake pH management - establish dedicated fund for lime applications.

- Otter River - Beaman Pond water quality - watershed management action plan.

- Wendell - Design for dam sluiceway rehab.

- Erving - Laurel Lake dam gate system rehab. (see Appendix I for detailed recommendations) 
- Otter River - Beaman Pond dam gate valve replacement.

- Otter River - Dam surfacing repair.

- Warwick - Sheomet Lake dam rehab. (see Appendix I for detailed recommendations)

- Warwick - Richards Reservoir dam rehab. (see Appendix I)

- Dunn Pond - Title of Stump Pond parcel transferred from City to DEM. (OK)

- Erving - Laurel Lake carrying capacity analysis for use of boats. (OK)

- Warwick - Recreation demand analysis for swimming area development at sheomet Lake. (OK)

NEW OR REPLACEMENT STRUCTURES

- Lake Dennison - Replace beach area bathhouse. (140K)

- Otter River - Replace remaining vault toilet. (100K) This item is also listed under Septic System Upgrades.

- Lake Dennison - Comfort stations upgrade. (500K) This item is also listed under Septic System Upgrades.

- Gardner Heritage V.C. - Acquisition / conversion of abutting structure for garage \& storage.

- Lake Dennison - Construct two smali contact stations for Upper Picnic Area. (OK)

- All parks with interpretive programs should consider interpreter centers/pavilions (20K) \& amphitheaters (5K).

\section{POTENTIAL RECREATION FACILITY EXPANSION}

- Lake Wyola acquisition and swimming area development.

- Erving campground expansion - 22 family sites, and a group site.

- Wendell cabin/yurt development.

- Wendell nordic ski center development.

- Ruggles Pond swimming area upgrade.

- Lake Dennison upper picnic area expansion and comfort station.

- Sheomet Lake swimming area development.

- Lake Dennison group camping area and comfort station.

- Erving - expansion of parking area for boat ramp.

- Determine best location at the western end of the cluster for playground facilities (eastern end has facilities at Dunn Pond). 


\section{ACKNOWLEDGEMENTS}

This report was prepared as a cooperative effort between the Division of Forests \& Parks and the Division of Resource Conservation, Massachusetts Department of Environmental Management.

Peter C. Webber, Commissioner - Dept. of Environmental Management

Division of Forests \& Parks

Todd Frederick, Director of Forests \& Parks

Carroll Holmes, Regional Forests \& Parks Director

Division of Resource Conservation

Peter Smith, Deputy Commissioner

Rich Thibedeau, Director - Bureau of Resource Protection

Andrea Lukens, Director - Office of Natural Resources

Jack Lash, GOALS Program Director

GOALS Planning Team

Carroll Holmes, Regional Forests \& Parks Director

Rodney Whipple, Assistant Regional Forests \& Parks Director

Joe Iagallo, Otter River management unit Supervisor \& Regional

Trails Coordinator

Mike Pelletier, Erving State Forest Supervisor

Wes Adams, Gardner Heritage State Park Supervisor

Hal Stowell, Wendell state Forest Supervisor

Dave Richard, Management Forester

Scott Nelson, formerly Warwick State Forest Supervisor

Dorothy Zug, formerly Gardner Heritage State Park Supervisor

Andy Backman, GOALS Program Planner

Plan Contributors \& Reviewers

Andrea Lukens; Director - Office of Natural Resources

Dick Whiting, Otter River state Forest

Ed Torcoletti, formerly Lake Dennison Recreation Area

Danny O'Brien, Bikeways \& Rail Trails Planner

Bill Rivers, State Managament Forester

Chuck Pernaa, Management Forester

Anne Marie Kittredge, Service Forester

Joe Smith, Service.Forester

Bob Hartzel, Lakes \& Ponds Planner

Brian Rod, GOALS Program Intern

Charlie Gibson, Project Manager - Dunn Pond Universal Access

Peter Brandenburg, DEM Trails Coordinator

Gary Briere, Chief - Bureau of Recreation

Karl Honkonen, Chief of Interpretive Services

Susan Ziegler, GIS Coordinator

Judy O'Kula, Region 4 Engineer 
Cathy Garnett, GOALS \& ACEC Program Planner

Gail Benedict, GOALS Program Planner

Chris Greene, Director - Office of Historic Resources

Nancy Dubosque, Great Falls Discovery Center

John Scanlon, DFW Wildlife Biologist

Tom Decker, DFW Wildlife Biologist

Lee Mclaughlin, DFW Aquatic Ecologist

Dave Basler, DFW Aquatic Ecologist

Gretchen Eliason, DFW Natural Heritage Program

David Kittredge, Associate Professor - UMass Dept. of Forestry Joseph Faloretti, Army Corps of Engineers

Leigh Youngblood, Mount Grace Land Conservation Trust

Cynthia Wood, Mount Grace Land Conservation Trust

Special thanks to the volunteers who contributed their time and ideas on the Trails Advisory. Committee.

Kenneth \& Lunette Prue, North Orange

Robert Phelps, Northfield

Tom Lively, Heath

Dean Zuppio, Rutland

Anne Zak, Wendell

Pat Gillespie, Bernardston

Rick Wilkey, Orange

Mike Magee, Orange

Barry Lacasse, Hubbardston

Robert Tucker, Concord

Bob Hicks, Wenham

Brian Peters, Warwick

Pat Fletcher, Westfield

Donald Flye, Athol

Peter Taylor, Clinton

John Keeney, Gardner

Henry Warchol, Westfield

David Chirnitch, Acton 


\section{REFERENCES \\ \& SOURCES FOR ADDITIONAL INFORMATION}

Ahern, Jack, Julius Gy Fabos, Niels laCour and F. Shan McAdoo. Conservation Networks and Greenways: Essential Components for a Sustainable Future. Proceedings of the 11th annual ESRI User Conference.

Banfield, Walter M., Frank Bequaert, Christopher Ryan. 1991. Metacomet-Monadnock Trail Guide. Appalachian Mountain Club Trails Committee of the Berkshire Chapter.

Brosnan, Deborah, John Elliot, Timothy Grubba, Ingri Quon. 1994. Guidelines for Monitoring and Detecting Visitor Impacts. in Bulletin of the Sustainable Ecosystems Institute.

Chadwick Martin Bailey Inc. 1995. SCORP 1995 - 2000 Demand Research: Report of Findings. Compiled for the Executive Office of Environmental Affairs.

Commonwealth of Massachusetts, Department of Environmental Management, and University of Massachusetts Department of Forestry. 1979. Field Manual for Silvicultural Prescription. Joseph Mawson and William Rivers.

Commonwealth of Massachusetts, Department of Environmental Management, Scenic Rivers Program. 1983. Millers River Management Plan. J. Geer \& R. Helfeld in cooperation with the Millers River Advisory Board.

Commonwealth of Massachusetts, Department of Environmental Management. 1983. Cultural Resources Inventory.

Commonwealth of Massachusetts, Department of Environmental Management. 1988. Statewide Comprehe ive Outdoor Recreation Plan $1988-1992$.

Commonwealth of Massachusetts, Department of Environmental Management. 1993. Forest Legacy Needs Assessment for Massachusetts.

Commonwealth of Massachusetts, Department of Environmental Management \& Office of Travel and Tourism. 1993. Massachusetts Heritage Discovery Network - Prototype Database - Final Report.

Commonwealth of Massachusetts, Department of Environmental Management. Five Year Capital Facilities \& Rehab Plan: Fiscal Years 1992 thru 1996 - Facilities Report.

Commonwealth of Massachusetts, Department of Environmental Management. (Draft) Wendell state Forest GOALS Management Plan. 
Commonwealth of Massachusetts, Department of Environmental Protection, water Pollution Control. 1991. Phase II Restoration of Dunn Pond.

Commonwealth of Massachusetts, Department of Fisheries, Wildlife \& Environmental Law Enforcement, Division of Fisheries \& Wildlife. 1992. Forest Management Plan for the Proposed Wildlife Management Demonstration Area at Northfield Mountain. John J. Scanlon, Wildlife Biologist.

Commonwealth of Massachusetts, Department of Fisheries, Wildlife \& Environmental Làw Enforcement, Natural Heritage \& Endangered Species Program. 1995. Massachusetts Priority Habitat Atlas.

Commonwealth of Massachusetts, Department of Natural Resources. 1971. Mt Grace Master Plan: Warwick - Mt Grace - Northfield State Forests.

Commonwealth of Massachusetts, Office of Travel \& Tourism. 1995. Analysis of Travel Planning Processes \& Key Motivators of Getaway Destination Selection. Prepared by Houston Effler Herstek Favat.

Commonwealth of Massachusetts, Office of Travel \& Tourism. 1993. Consumer Attitude Research Study. Managed by Houston, Effler \& Partners. Conducted by Dorr Research Corporation.

Commonwealth of Massachusetts Regulations 304 CMR 7 thru 20.

Commonwealth of Massachusetts, senate Publication 2425. 1996. Report of the Special Commission on Forest Management Practices.

Cortell Associates. 1987. Diagnostic Evaluation, Management Alternatives \& Recommendations - 21 Commonwealth Lakes and Ponds.

Cortner, Hanna and Margaret Shannon. July, 1993. Embedding Public Participation. pp 14-21 in Journal of Forestry.

DeGraaf, Richard and Deborah Rudis. 1986. New England Wildlife: Habitat, Natural History and Distribution. USDA Forest Service, Northeastern Forest Experiment Station - General Technical Report $\mathrm{NE}-108$.

DeGraaf, Richard, and David M. Richard. 1995. Forest Wildlife of Massachusetts: Cover Type, Size Class \& Special Habitat Requirements. USDA Forest Service, University of Massachusetts and Massachusetts Counties cooperating.

Environmental Institute, University of Massachusetts. 1990. An Atlas of Massachusetts River Systems: Environmental Designs for the Future. Published for the Massachusetts Division of Fisheries \& Wildlife. Edited by Walter E. Bickford and Ute Janik Dymon. 
Frost, Karro. 1994. Veqetational Survey of the Zellmer, Maynard \& Earle Properties. Unpublished report prepared for Mount Grace Land Conservation Trust.

Golodetz, Alisa. 1993. Historical Patterns of Land Protection in North Central Massachusetts: The Emergence of a Greenway. Unpublished report prepared for Hampshire College and the Harvard Forest.

Horsley Witten Hegemann, Inc. 1990. Lake \& Pond Management Field Manual. prepared for a Department of Environmental Management workshop.

Johnson, Darryll R. and Mark E. Vande Kamp. 1996. Extent and control of resource damage due to noncompliant visitor behavior: A case study from the U.S. National Parks. in Natural Areas Journal vol. 16 , no. 2 .

Kuss, Fred R., Alan R. Graefe, and Jerry J. Vaske. 1990. Visitor Impact Management: A Review of Research. National Parks and Conservation Association: Washington, D.C.

Leahy, Christopher. 1988, revised 1993. Eden's End: The Case for Ecological Protection in Massachusetts. Massachusetts Audubon Society Report.

Living Lakes, Inc. 1992. Final Report - Laurel Lake. Living Lakes Program Report.

Mawson, Rivers \& Fisher. 1978. A Forest Land Classification System for Massachusetts. University of Massachusetts Cooperative Extension Service.

Massachusetts Audubon Society. 1989. Watershed Decisions: The Case for Watershed Protection in Massachusetts. Edited by Elizabeth A. Colburn and Robie Hubley.

Midstate Trail Committee. 1989. Midstate Trail Guide: A Hiking Map Through Worcester county. printed by Eastern Mountain Sports in cooperation with Massachusetts Department of Environmental Management.

Noss, Reed F. and Allen Y. Cooperrider. 1994. Saving Natures Legacy. Island Press, Washington, D.C. 416 p.

Rezendes, Paul. 1994. 'Wildlife Inventory: The Earle Project Warwick, Mass. Unpublished report prepared for Mount Grace Land Conservation Trust.

Richard Sandler \& Associates / CRC Direct Marketing Services. 1995. Recreation Consumer Attitude Survey. Unpublished report prepared for the Department of Environmental Management. 
Rubinstein, Lynn. 1990. Discontinuing Town \& County Roads. Prepared for the Franklin County Planning Department, with funding from Massachusetts Department of Public Works.

Ryan, Christopher. 1987. Understanding Public Ways. Unpublished report prepared for the University of Massachusetts.

Sample, V. Alaric. July, 1993. A Framework for Public Participation in Natural Resource Decision Making. pp 22-25 in Journal of Forestry.

Scanlon, John J. 1992. Managing Forests for Wildlife Diversity. in Northeast Wildlife, Volume 49.

Snowmobile Association of Massachusetts. 1991. Massachusetts Snowmobile Corridor Trail Map.

Society of American Foresters. 1991. Task Force Report on Biological Diversity in Forest Ecosystems.

Stolzenburg, William. July/August, 1991. The Fragment Connection. pp 19-25 in Nature Conservancy.

Urban Research Development Corporation - Bethlehem, PA. 1977. Guidelines for Understanding and Determining Optimum Recreation Carrying Capacity. Prepared for USDI Bureau of Outdoor Recreation.

U.S. Environmental Protection Agency. The Massachusetts Ecological Regions Project. Prepared by the EPA Environmental Research Lab, Corvallis, Oregon, for the Massachusetts Department of Environmental Protection.

USDA Soil Conservation Service. 1967. Soil Survey of Franklin County, Mass.

USDA Natural Resources Conservation Service. Interim Soil Survey of Northern Worcester County, Mass.

Wetzel, R.G. 1975. Limnology. Saunders College Publishing, Philidelphia. $743 \mathrm{p}$. 


\section{APPENDIX A}

\section{Massachusetts State Forest Road Classification System}

The Classification System was put into effect in june of 1995 on all DEM properties. Its purpose is to serve as a means through which the hundreds of miles of roads in the State forest and Park system can be inventoried. evaluated and comprehensive plans for their maintenance developed. Addizionally. it puts forth siandard design and maintenance specifications and provides a framework within which budgers can be developed.

\section{Road Classes;}

A three character code is used to describe the Road Class for each road in the State Forest system both its present condition and what its future state should be. The code would be expressed as a fraction, with the numerator representing the proposed class and the denominator its present class (proposed/present). The first character would indicate the Type (the specs in the table and drawings) from Type I through Type 4. The second character would describe the Maintenance Level and the third character, the type of Traffic Management for the road.

\section{For example:}

\section{$\frac{3 \text { A B }}{4 \cdot \text { A A (Present) }}$}

The foregoing describes a a road that presently has a narrow, natural surface, is not (or is poorly) maincained and has no access controls (is open to the public). It is recommended that it be upgraded to a cype 3 road by the addition of gravel, graded and that drainage structures be installed as per the specifications on the following two pages. Future access controls in the form of year-round gates are also recommended.

Type:

1. Paved, aspha!t, stone and oil, etc., 2 lane, $40 \mathrm{mph}$.

2. Processed gravel or crushed stone surface, 2 lane, $20^{\prime}$ wide, $25 \mathrm{mph}$.

3. Bank run gravel surface, single lane, $14^{\prime}$ wide, $15 \mathrm{mph}$.

4. Natural surface, single lane, $10^{\prime}$ wide, $10 \mathrm{mph}$.

\section{Maintenance Level:}

A. Maintained for low clearance (<6") vehicles (passenger cars). Surface graded (if gravel), culverts cleaned and ditches mowed annually. Inspected at least quarterly and after major storm events.

B. Maintained for high clearance ( $>6 "$ ) vehicles (pickups and $4 \mathrm{wds}$.). Inspected at least quarterly and after major storm events. Spot maintenance to prevent degradation of the road prism and drainage structures. Mowed to retard invasion by woody plants.

C. Maintained for occasional 4wd administrative use only. Inspected at least quarterly and after major storm events. Bridges and culverts removed. Water bars, rolling dips and broad-based dips installed. Mowed to retard invasion by woody plants.

D. Not maintained. Culverts plugged or damaged; bridges unsafe; significant (>4") surface erosion; ditches brushed in or non existent.

E. Deactivated. Bridges and culverts removed. Deep (2') water bars, rolling dips and broad-based dips installed. Sidehill sections outsloped. Allowed to revegetate.

Traffic Management:

A. Open to traffic year-round

B. Gated seasonally

C.' Gated year-round

D. Fixed barriers (boulders, posts, etc.) 


\section{Minimum Standards by Road Type}

Please note that these are minimum specs, e.g.: a Type 3 road could be surfaced with crushed stone, a Type 4 road could be 12 ' wide. etc.

Strict interpretation of clearing widths is for new construction - healthy root systems and heavy equipment can't coexist. Along existing roads larger, vigorous, "specimen" trees that do not interfere with maintenance should be retained. However, smaller trees and shrubs occurring in the clearing limits and high risk trees outside the clearing limits that may fall into the roadway or ditch should be removed and not be allowed to develop into future problems. This is a judgement call.

Most specs for Type One roads are case specific and are subject to development by Engineering. For the time being, detailed specifications for surfacing material and subgrade on all types of roads will also be done on a case by case basis in consultation with Engineering. These specs. will be developed with their help as we move along.

\begin{tabular}{|c|c|c|c|c|}
\hline & Type 1 & Type 2 & Type 3 & Type 4 \\
\hline Back slope & & $<1: 1$ & $<1: 1$ & $<1 / 2: 1$ \\
\hline Ditch bottom & & $V$ to $4^{\prime}$ & $\mathrm{V}$ & $\mathrm{V}$ \\
\hline Side slope & & $<3: 1$ & $<1 \mid 1 / 2: 1$ & $11 / 2: 1$ \\
\hline Ditch depth & & $>11$ & $>1^{\prime}$ & $>.5^{\prime}$ \\
\hline Base type and thickness & & Site specific & Site specific & Native \\
\hline Surface & Asphalt & Proc. gravel/stone & Bank run gravel & Native \\
\hline Roadway width & & $20^{\prime}$ & $14^{\prime}$ & $10^{\prime}$ \\
\hline Shoulder width & & none & none & none \\
\hline Crown slope & & $1 / 8 "$ - $1 / 4^{\prime \prime}$ per $\mathrm{ft}$. & $1 / 4^{\prime \prime}-1 / 2^{\prime \prime}$ per $\mathrm{ft}$. & optional \\
\hline Design speed & & $25 \mathrm{mph}$ & $15 \mathrm{mph}$ & $10 \mathrm{mph}$ \\
\hline $\begin{array}{l}\text { Structure width } \\
\text { (bridges, gates) }\end{array}$ & & $20^{\prime}$ & 14 & $14^{\prime}$ \\
\hline Sight distance & & $200^{\prime}$ & $150^{\prime}$ & $100^{\prime}$ \\
\hline Curve radius & & $125^{\prime}$ & $75^{\circ}$ & $50^{\prime}$ \\
\hline Turn outs & & Not needed & $4 / \mathrm{mile}$ & Opportunistic \\
\hline Max. Grade: Short / Sustained & & $10 \% / 8 \%$ & $12 \% / 10 \%$ & $14 \% / 12 \%$ \\
\hline Bridge loading & $\mathrm{HS}-20$ & $\mathrm{HS}-20$ & $\mathrm{HS}-20$ & $\mathrm{HS}-20$ \\
\hline Design storm (>2' pipe) & $50 \mathrm{yr}$. & $50 \mathrm{yr}$. & $25 \mathrm{yr}$. & $10 \mathrm{yr}$. \\
\hline Total cleared width & & $\begin{array}{c}\text { Back slope + } 5^{\prime} \\
\left(38^{\prime}\right)\end{array}$ & $\begin{array}{c}\text { Back slope }+5^{\prime} \\
\left(32^{\prime}\right)\end{array}$ & $\begin{array}{c}\text { Back slope + } 5^{\prime} \\
\left(24^{\prime}\right)\end{array}$ \\
\hline
\end{tabular}



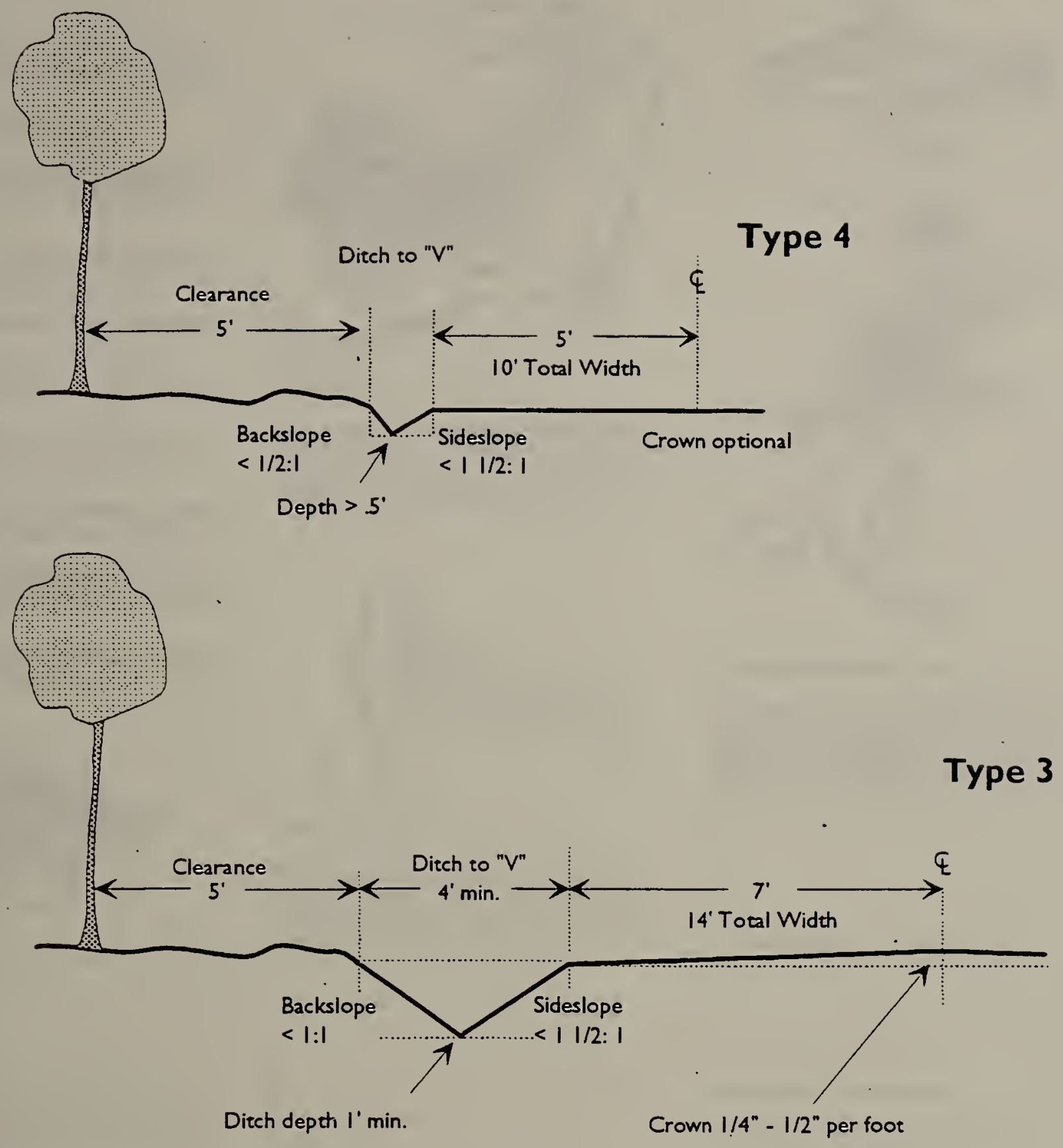

Type 2

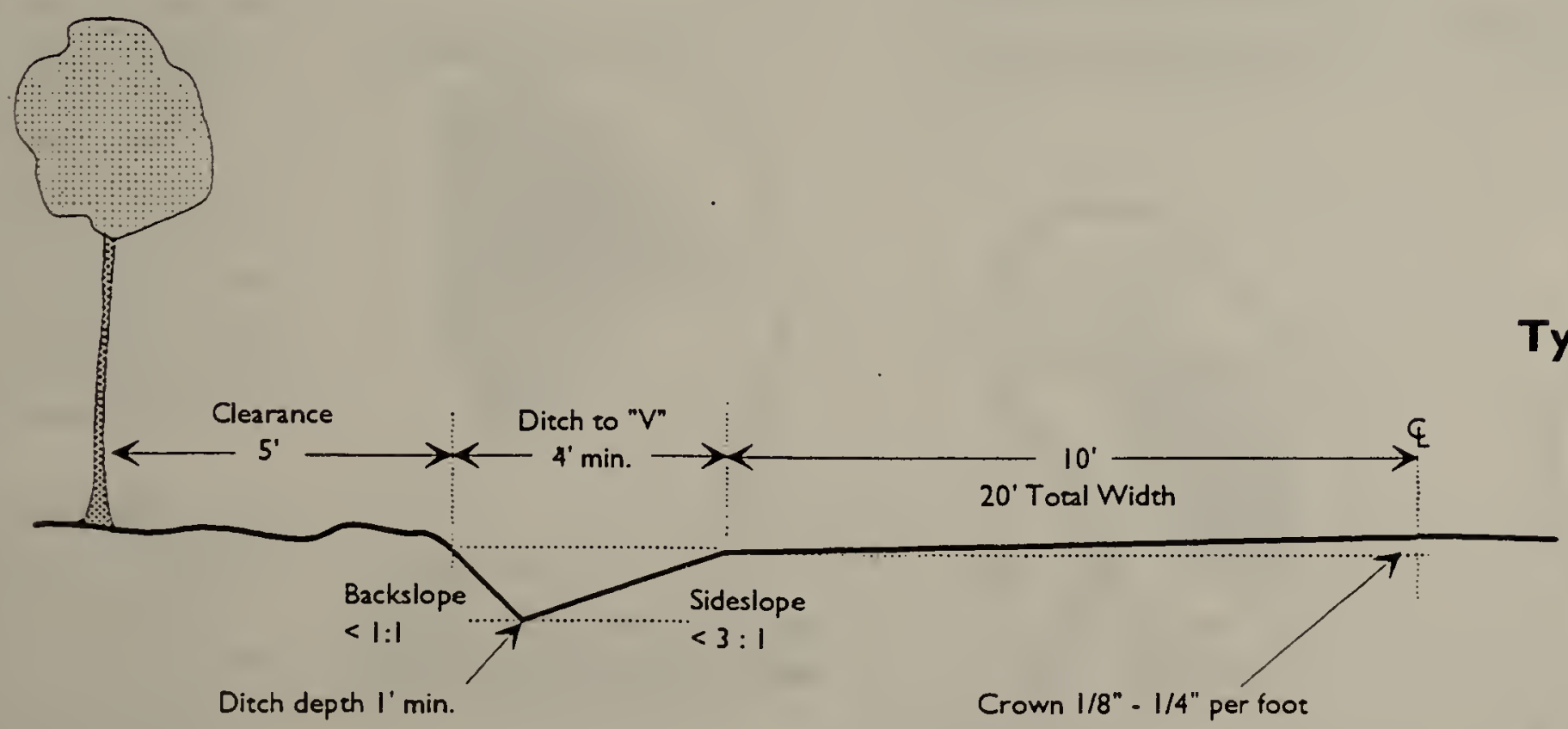


Regulations

1. All areas will be closed to the public between dusk and dawr.

2. Fires are permitted in fireplaces only.

3. Picnicking and other use of food and alocholic beverages are allowed only in designated camping areas.

4. Litrering and waste disposal of any kind are prohibited on both land and water.

5. Only battery-operated power boats are allowed on the ponds.

6. Motorized off-road vehicles are restricted to designated trails.

7. Camping is allowed only in designated camping areas.

8. All boars must be equippod with one Coast Guard approved personal floaraion device per person.

9. Hunting, fishing and trapping are subject to the Division of Fisheries and Wildlife general laws, regulations and staurtes.

10. Please refer to Fish and Wildife Laws, Commonwealth of Massachusetts, Division of Fisheries and Wildlife.

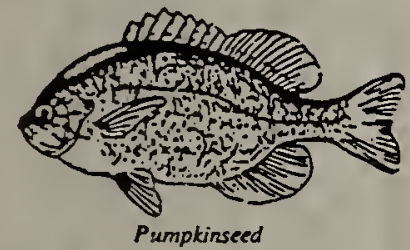

$V$

isitors to Myles Standish State Forest often ask. "where, is the best fishing?" This guide tries to answrer that question by highlighting six ponds chosen for thei reputation as good fishing spots.

The Kettle Ponds

Most of the ponds at Myles Standish State Forest were formed over 10,000 years ago as the end of the last ioe age. The retreating glaciers lefi behind large blocks of buried ice which later melted to form depressions in the landscape. These kerileholes as they are called filled with groundwater so form round shape ponds

Today these ponds are inhabited by a wide variery of plamis and animals including such native fish species as yellow perch, eals, chain pickerel. pumplinseod, sunfish and bompouk Orher inroduced species include: brown trour, rambow trour, largernouth bass, smallmouth bass, blucgill sunfish and whire perch. $A$ few of the kerle ponds in the area are borre to the endangered red-bellied urite. while a mumber of rare and endangerod plans species are found along the shores of these pands

Unfortuanately, most freshwrler poods in this area are suffering from the adverse effeces of acid precipitacion believed to be coused by the burning of fossil fuels. The emmission of sulfur and nitrogen 23 a byproduct of fossil fuel combustion mixes in the atroosphere wit water vapor which then condenses and falls to the ground as acid rin and snow. These ponds do not hav the "buffering capacity" or ability to counteraca the effects of highly acidified whers. As a resulh the water's acid level is increasing, and scientios foar this will be hamulul lo many fish and ocher aquatic organisms.

Please Protect All Wildlife and Prevent Water Pollution

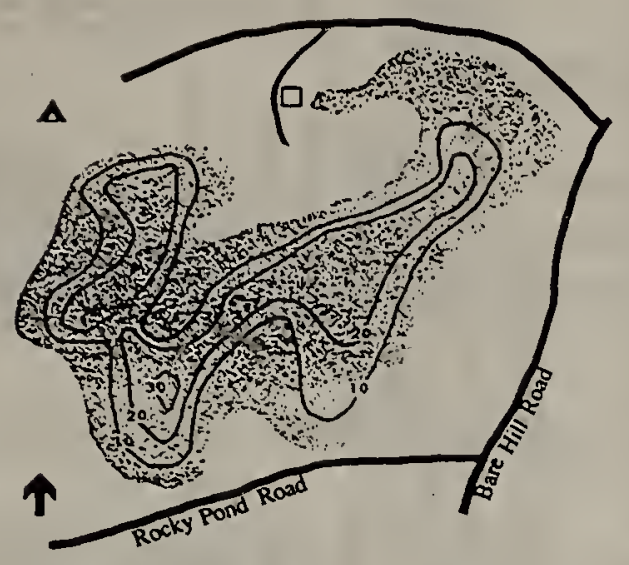

CURLEW POND 43 acres

Fishing is fair. Sorne large bass and pickerel. Shoreline is developed and parts are privately owned, limiting acoess for shore fishing. Canoes can be carried in or make use of the launch site an the northeast side of the pond.

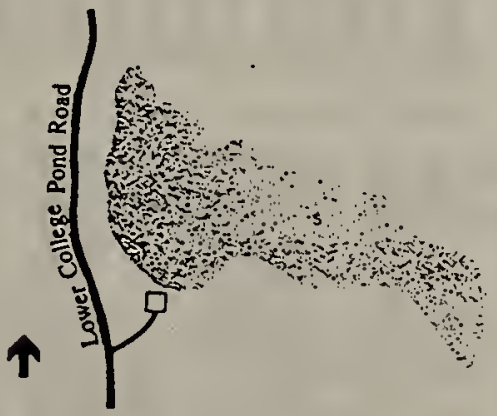

NEW LONG POND 23 acres

Bass fishing. This small pond aiso has some yellow perch. The shoreline is undeveloped and there is easy accoss for shore fishing or small boats. Camping at this pond is for non-profit organizations only.

This brochure is printed on recycled paper.

EAST HEAD RESERVOIR 86 acres

\section{A \\ Fishing Guide to Myles Standish State Forest}

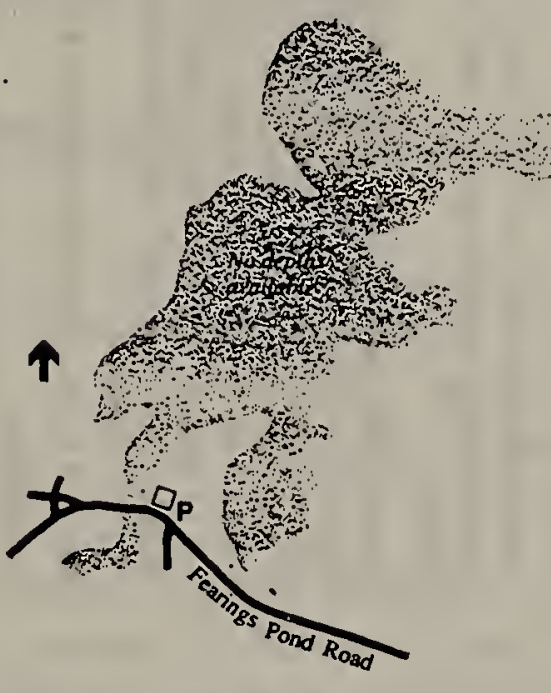

The reservoir is the best choice for fishing from a canoe or small boat. Shore fishing is prohibited. There is some excellent bass fishing along the weedy undeveloped shorelixe. This is the largest body of water within the state forest boundaries, but is privately owned.

Key

$\square$ Fisherman's Landing

A Camping Area

P Paking

Moss access points are nor marked.

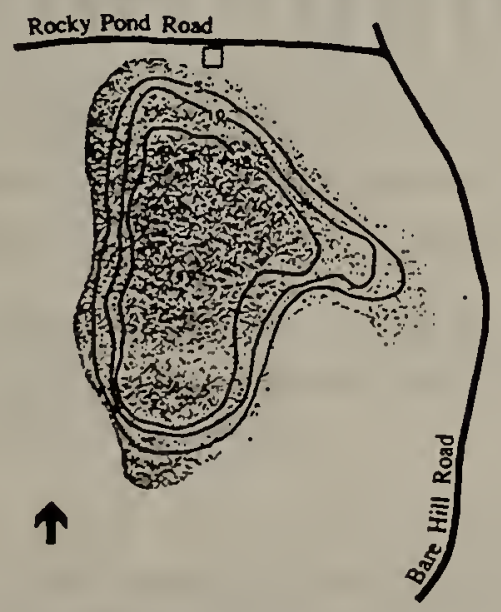

ROCKY POND 20 acres

Easy acess for cances and small boats. This pond has a partially undeveloped shoreline, with good cover for bass, pickerel and brown bulthead. Acoess for fishermen is on the south side of the pond.

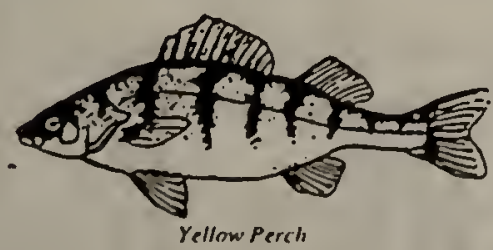

\section{Conservation Guidelines}

- Put litier where it belongs. Use trash receptacles or carry out what you carry in.

a Do not disturb shoreline vegetation by driving or walking along pond edges. The plants here help to maintain the ecological balance of the ponds.

a Do nol use soaps or detergents in or near ponds: these substances are harmful to fish and other wildlife.

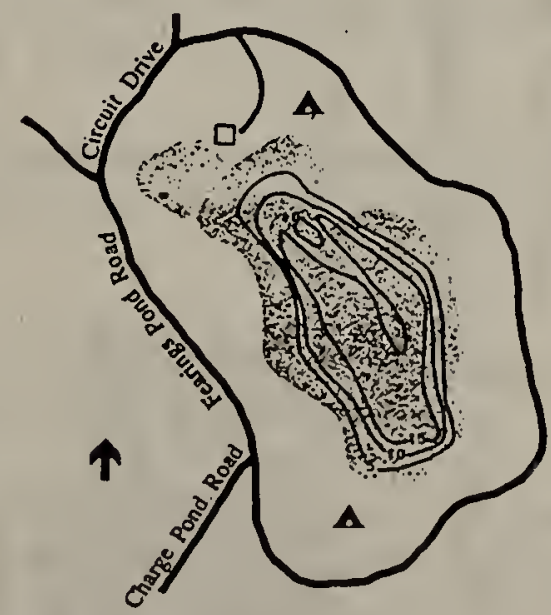

FEARINGS POND 24 acres

This is the only pond in the forese socked with troue Fishing for brown and rainbow rour is best in the fall and spring. There is good fishing for bass and bluegill sunfish in the summer. Canoes can be carried in. There is a partially developed shoreline. a Bc careful with fire.

a Respect all wildlifc.

a Release all unwanted fish carefully.

.7. Read and obcy all fishing regulations. Abstracts of the regulations are available at the contact station.

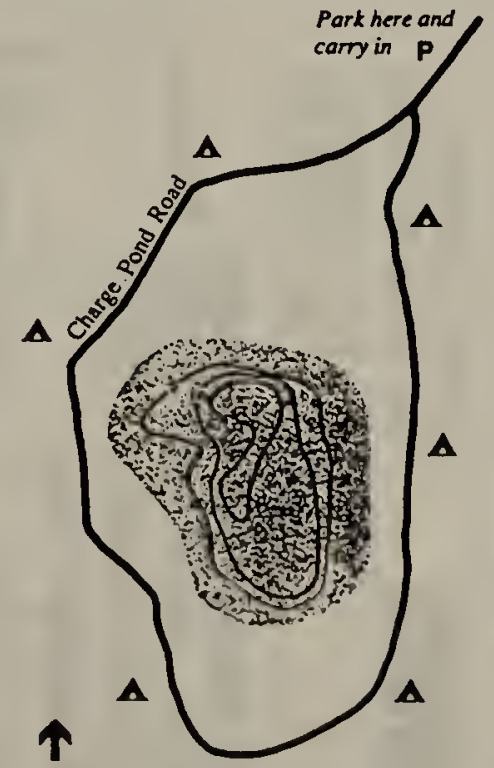

CHARGE POND 18 acres

Perch and sunfish are plentiful in Charge Pond. Fishing for smallmouth bass is fair. The pond has an undevelopod shoreline with good access for shore fishing. Canoes can be camed in. 


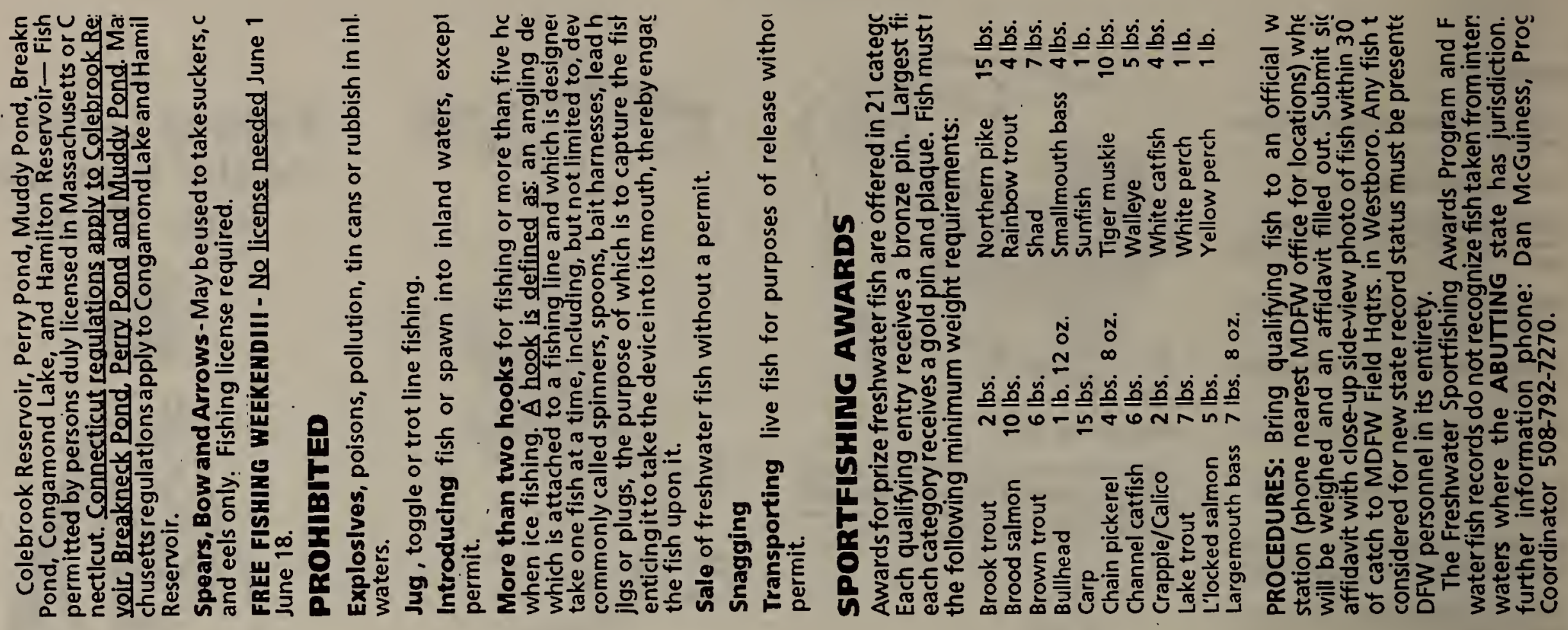

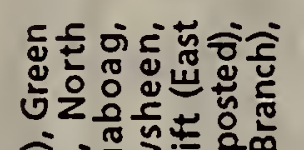

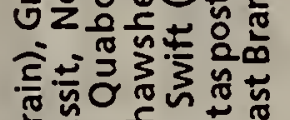

产的言造

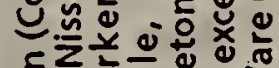

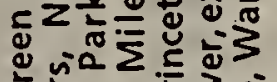

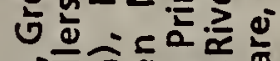

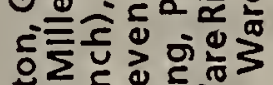

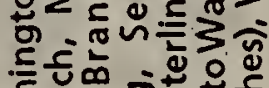

ही

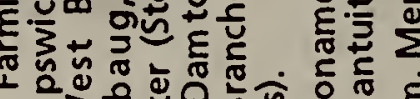

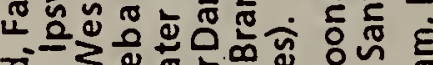

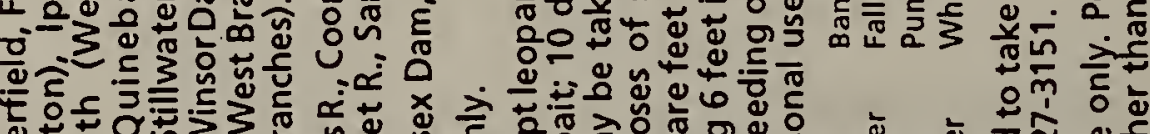

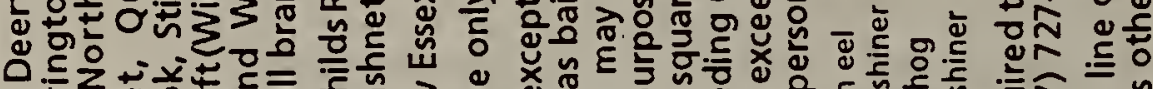

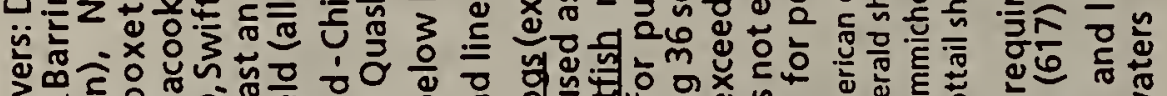

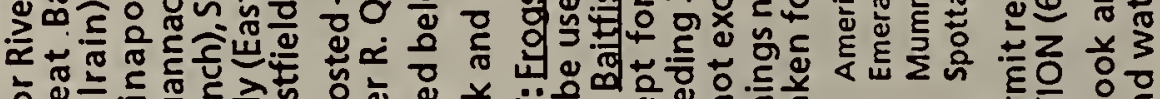

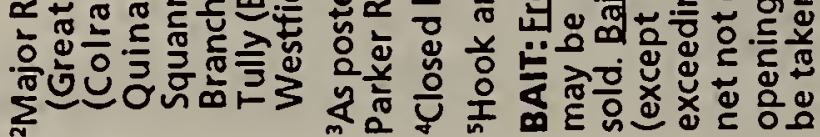

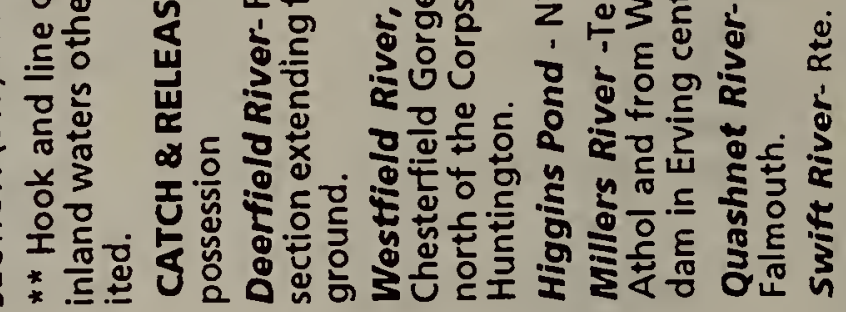

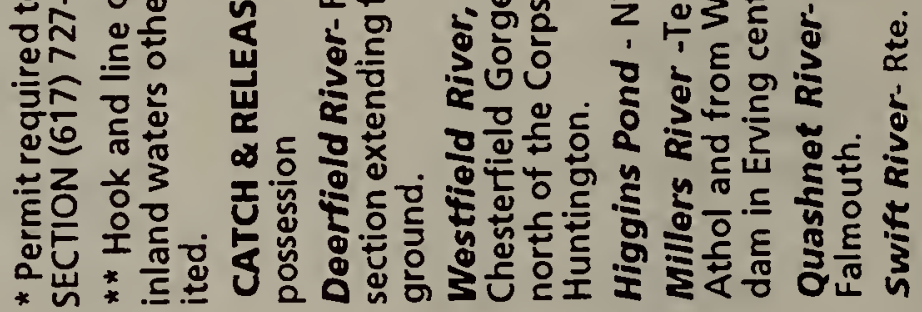

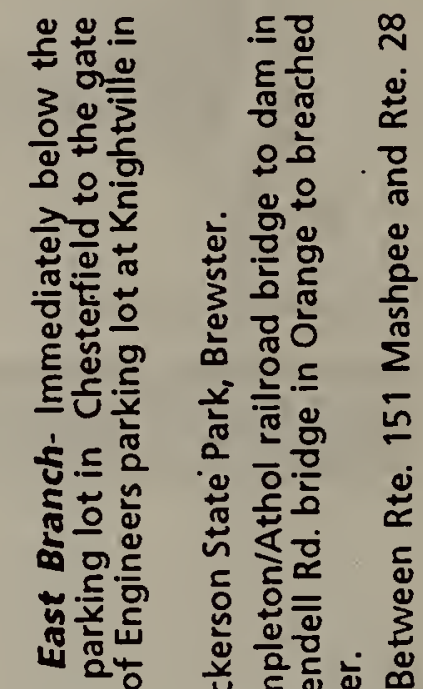

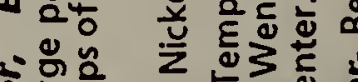

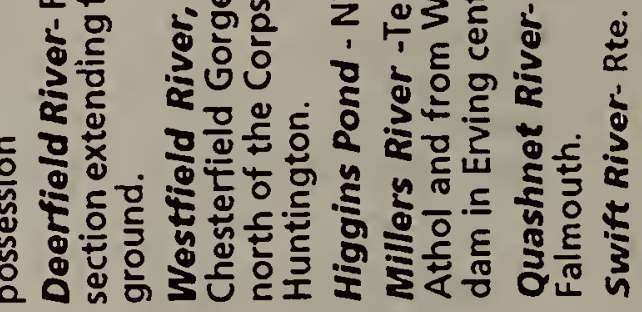

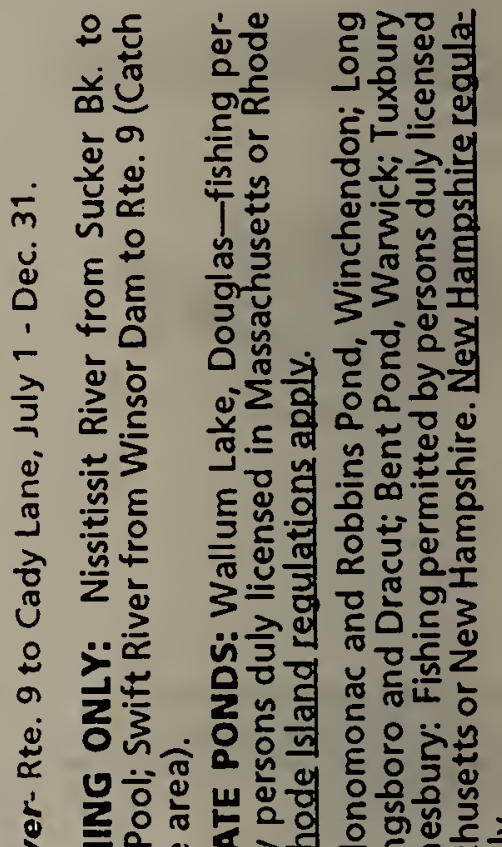

\%

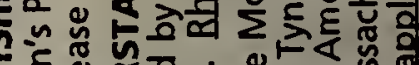

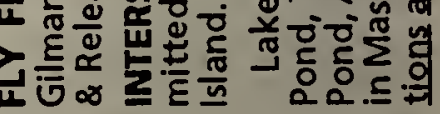

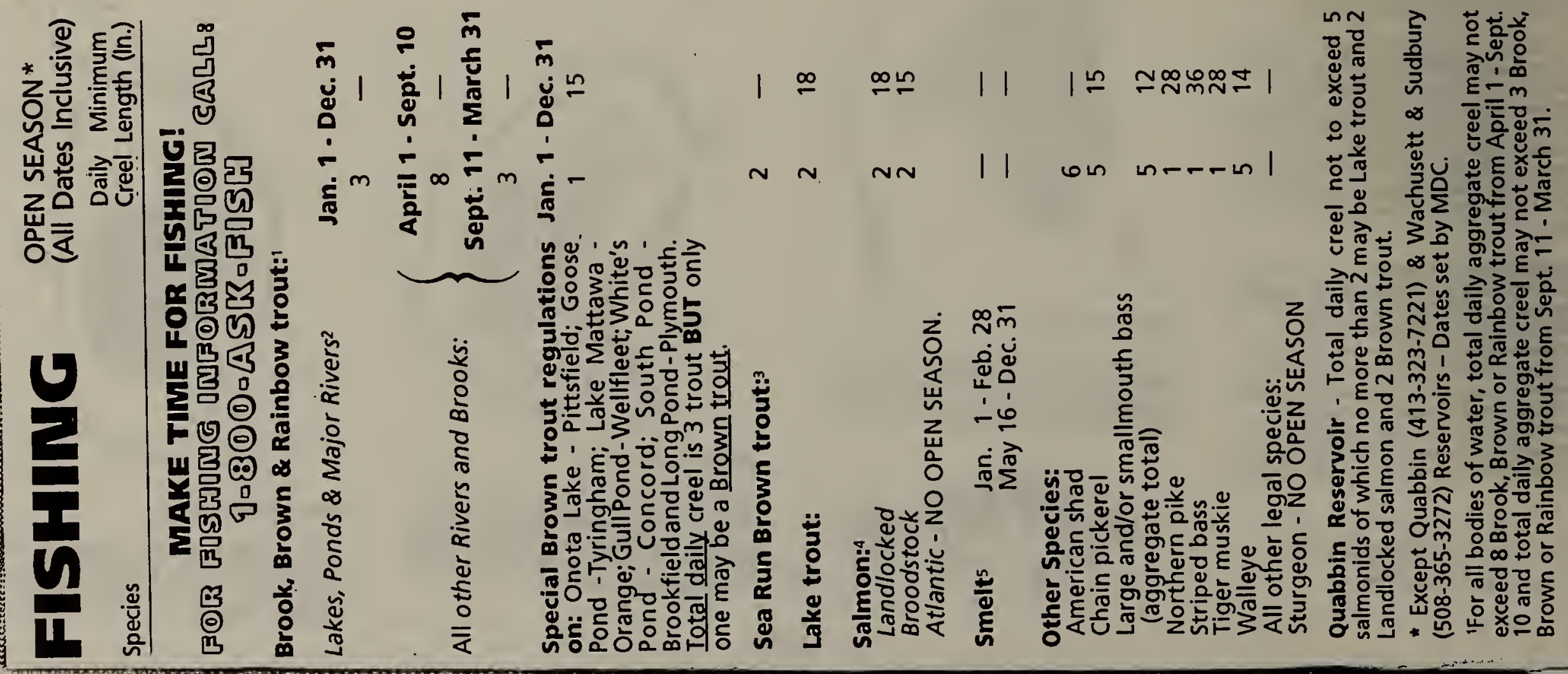




\section{APPENDIX C}

CARRYING CAPACITY: Factors influencing optimum capacity and suggested optimum capacity ranges for various recreation activities.

\section{Primary Factors Influencing the Selection of Optimum Capacity - Factors Common} to Many Activities

A list of primary factors which affect the choice of an optimum capacity level is provided below each of the suggested optimum capacity ranges. These factors can be used by recreation planners and administrators as a basis for listing factors, observing conditions and calculating the "net effect" figures indicated in the five step process discussed earlier in this Chapter.

The same factors affect the optimum carrying capacity of many activities. Those factors, which are comon to many activities, are listed below and are referred to when appropriate under the suggested optimum capacity range for a given recreation activity. The most comon factors influencing optimum carrying capacity for many activities are:

A. Location of the Recreation Activity Area = Recreation participants in an urban area will generally expect, tolerate and accept higher use densities than participants who travel to remote locations; for this reason, an activity area located within an urban area can generally be used at a higher optimum capacity than an area in a remote location.

B. - Size of the Recreation Activity Area - The size of a recreation activity area affects optimum carrying capacity because of the generally unfavorable cumulative effect that is perceived when there are many recreation particlpants located over a very large area; therefore, very large activity areas should probably be developed and operated at a lower capacity level than smaller areas.

C. Quality of Site Amenities - The number and quality of site amenities affects a person's willingness to tolerate and accept higher levels of capacity; therefore, recreation sites with amenities such as scenic natural features, views or vistas can generally be developed and operated at a higher optimum capacity level.

D. Proximity to Convenience Facilities - Activity areas conveniéntly located near comfort and other support facilities can generally have higher use intensities because they are developed and operated at a higher optimum capacity level than areas which are inconvenient.to support facilities.

E. Homogeneous User Groups - Areas used by similar socio-economic, age and interest groups can generally be developed and operated at higher optimum capacities than areas used by dissimilar groups.

F. Length of Day - For some activities, night lighting can extend the length of the user day, thus increasing the capacity of the activity area.

G. Duration of Use - The duration of use varies by activity and by participant type. It is important to recognize that management policies regarding the duration of use have a definite effect on optimum carrying capacity.

H. Vulnerability of the Site - A site which is environmentally sensitive because of vegetation which cannot withstand abuse, soil compaction problems, poor drainage and runoff, erosion, climatic condition, and other similar features should be developed and operated at a much lower capacity level. Sites with these natural features should be considered only for activities which are not, by nature, likely to be injurious to the site. 
SWIMMING, BEACH

Suggested Optimum Capacity Range

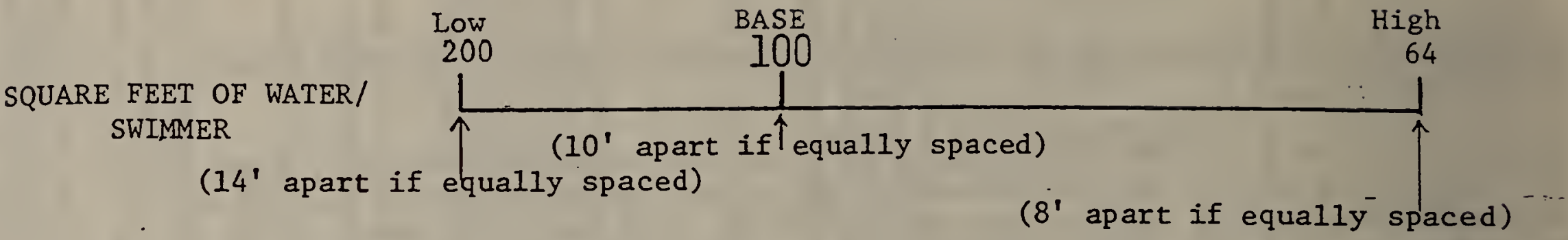

Primary Factors Influencing Selection of Optimum Capacity Leve1 ${ }^{4}$

- Refer to Factors A and E

- Waders/Swimmers - Waders require less space than swimmers; thus, a beach area which has a preponderance of waders could accommodate more people per acre of water.

- Weather, Season, Time of Day - The number of swimmers will vary depending upon the weather, season and time of day.

- Extent of Beacht - Depending upon the depth of the beach area, the beach area might be the limiting factor determining optimum capacity.

(*NOTE: Where the beach area is the limiting factor, the suggested range for Sunbathing (page III-3) can be used to determine the appropriate capacity)

SUNBATHING

Suggested Optimum Capacity Range

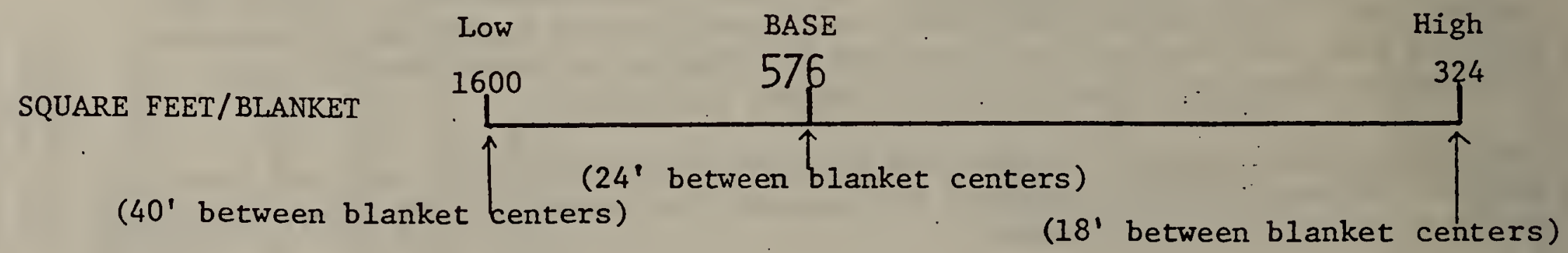

\section{Primary Factors Influencing Selection of Optimum Capacity Level}

- Refer to Factors A, B, C, D, E and H

- Weather, Season, Time of Day - The number of sunbathers will vary depending upon the weather, season and time of day. 
CAMPING, PRIMITIVE

Suggested Optimum Capacity Range

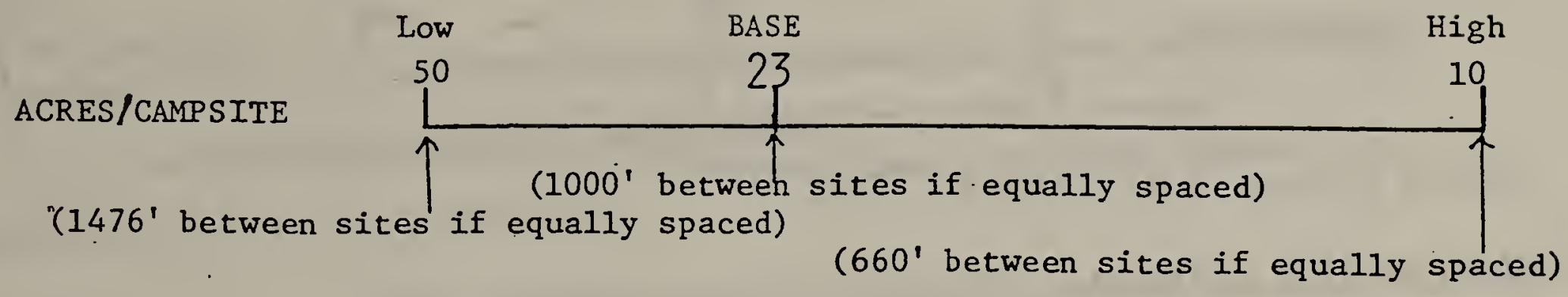

\section{Primary Factors Influencing Selection of Optimum Capacity Leve1}

- Refer to Factors $\mathrm{A}, \mathrm{C}$ and $\mathrm{H}$ :

- Degree of Privacy Afforded by the Site - The type of vegetation and the topographic characteristics of the site affect the perceived closeness of the campsites; a 100-acre area that is heavily wooded and moderately sloping can accommodate more campsites per acre than a 100-acre open field:

CAMPING, TENT AND TRAILER

Suggested Optimum Capacity Range

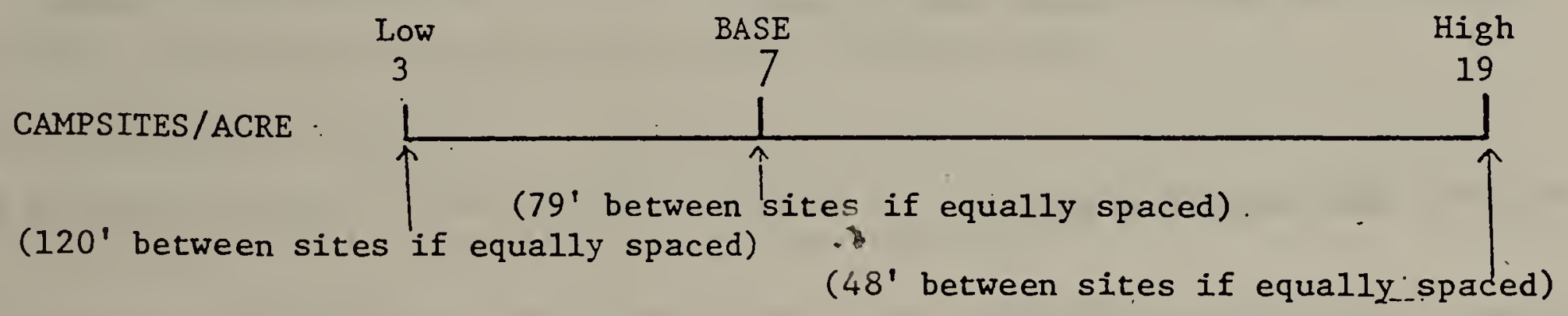

Primary Factors Influencing Selection of Optimum Capacity Level

- Refer to Factors A, B, C, D and H

- Degree of Privacy Afforded by the Site - The type of vegetation, forest and field and slope characteristics, affect the perceived closeness of campsites. A densely-wooded, moderately-sloping area can accommodate more campsites per acre than an open field ór lawn.

- Siting Limitations - The type of vegetation, e.g., field or forest, and slope . characteristics also affect the ease of locating campsites. For example, a lower density may be appropriate if the area has slopes steeper than 10 percent.

- Proximity to Other Activity Areas - Areas in very close proximity to swimming, boating, historical features or other activity areas are generally attractive campsites and can accommodate more per acre than an area with no related activities nearby. 


\section{PICNICKING}

\section{Suggested Optimum Capacity Range}

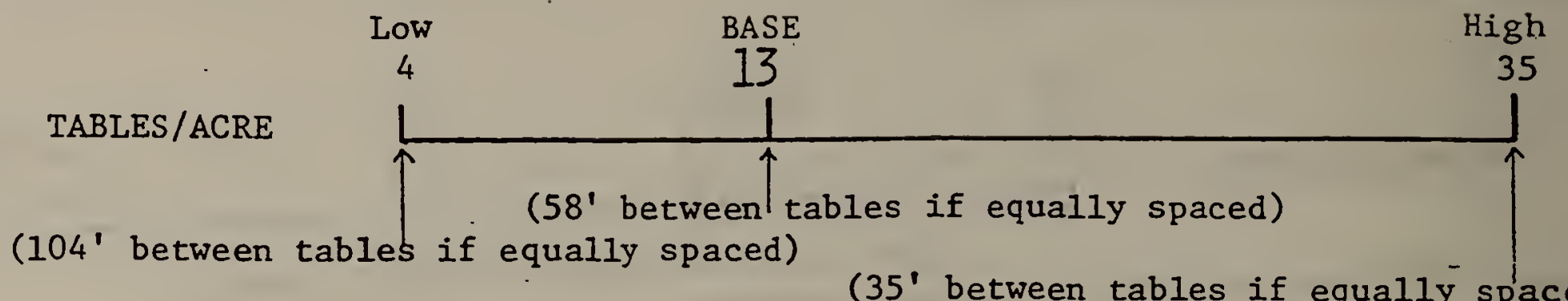

(35' between tables if equally' spaced)

\section{Primary Factors Influencing Selection of Optimum Capacity Level}

- Refer to Factors $A, B, C, E$, and $H$

- Degree of Privacy Afforded by the Site - The type of vegetation, forest and field and slope characteristics affects the perceived closeness of picnic sites. A densely wooded, moderately sloping area should accommodate more tables per acre than an open field or lawn.

- Siting Limitations - The type of vegetation, e.g., field or forest and slope characteristics also affect the ease of locating picnic table sites. For example, a lower density may be appropriate if the area has slopes steeper than 10 percent.

- Configuration of Picnic Area - The shape of the picnic area has some bearing on picnic table density; lineal-shaped picnic areas can accommodate a higher density than square-shaped picnic areas.

BOATING, NON-POWER FLAT WATER

Suggested Optimum Capacity Range

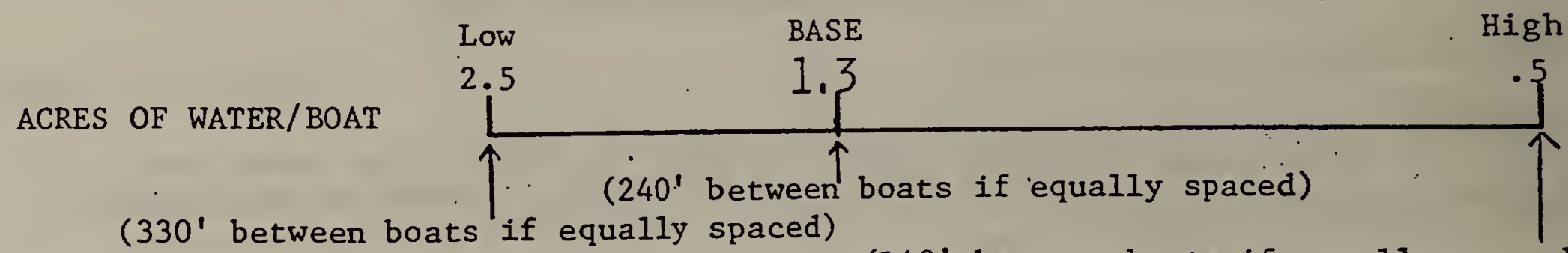

(148' between boats if equally spaced)

Primary Factors Influencing Selection of Optimum Capacity Level

- Refer to Factors $A, B$ and C

- Boat Type - Row boat and canoes require less space than sailboats because they are more easily maneuberable; therefore, areas where there are sailboats also using the areas should accommodate fewer boats per acre. 
SKIING, WẠTER

Suggested Optimum Capacity Range

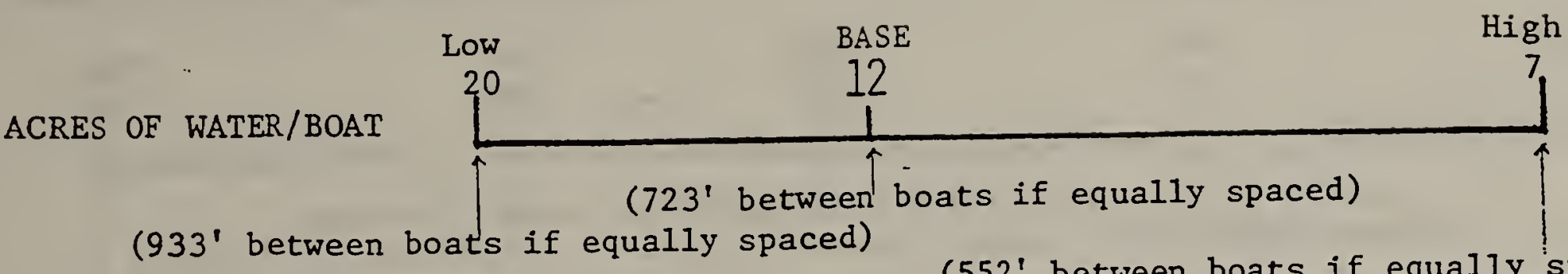

( $933^{\prime}$ between boats if equally spaced) (552' between boats if equally_spaced)

BOATING, UNLIMITED POWER

Suggested Optimum Capacity Range

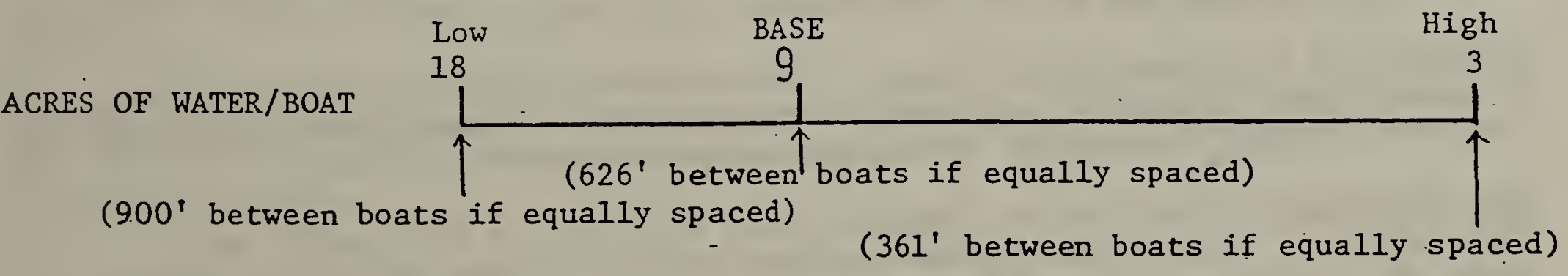

Primary Factors Influencing Selection of Optimum Capacity Level

- Refer to Factors $A, B$ and $C$

- Type of Aquatic Life - Certain types of aquatic life, under certain circumstances, cannot withstand large volumes of boat traffic.

- Multiple Use of Water Area - The number of boats/acre should be lower if other activities, such as swimming, are also allowed in the boating area.

- Depth of Water - Water areas that are shallow should accomodate fewer boats per acre.

- Rate at Which Water is Circulated Through System - The faster water is circulated through the system, the more boats the water area can accommodate from the standpoint of polluting the water with oil, etc.

- Shoreline Configuration - Water areas with very irregular shorelines should, on the basis of safety, accommodate fewer boats per acre than those with regular, even shorelines.

- Degree of Policing - Water areas that are policed can accommodate more boats per acre than those which are not policed.

- Circulation Patterns - Water bodies with defined ski lanes can safely accommodate more boats per acre than unmarked water bodies which, allow a random pattern of tow paths. 
FISHING, SHORELINE

Suggested Optimum Capacity Range

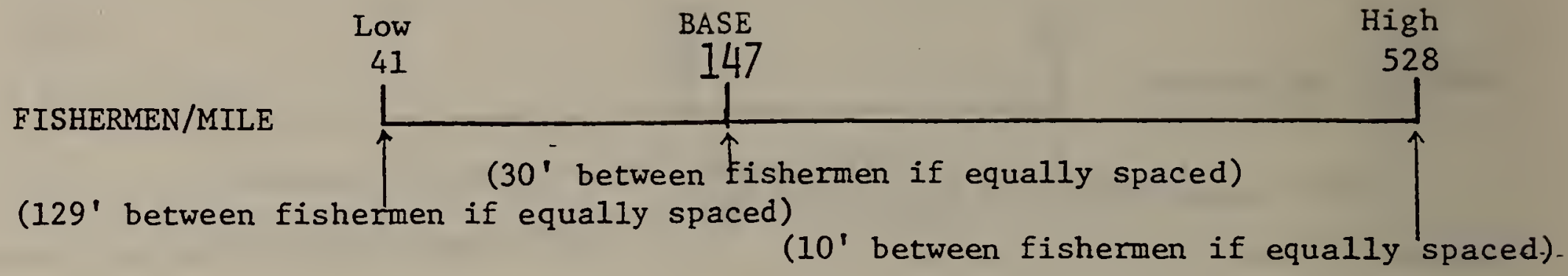

Primary Factors Influencing Selection of Optimum Capacity Level

- Refer to Factors A and B

- Fish Availability - Generally, fishermen will accept and tolerate more fishermen per mile of shoreline if they are catching fish; therefore, streams and rivers that are either well-stocked or naturally abundant with fish can accomnodate more fishermen per mile of shoreline.

- Tolerance of Fish Species to People - Certain types of fish are more tolerant to people than other types, streams containing less tolerant species, such as the trout, should accommodate less fishermen per mile of shoreline.

- Type of Fishing - The type of fishing, i.e., fly, bait or spin cast, surf fishing, etc., affects the optimum carrying. capacity of the shoreline; certain types of fishing, e.g., surf fishing, require greater distances between fishermen.

- Stability of Shoreline - Certain shorelines physically are more stable than others and can accomodate more fishermen per mile without increasing erosion and sedimentation.

HUNTING, WATERFOWL

\section{Suggested Optimum Capacity Range}

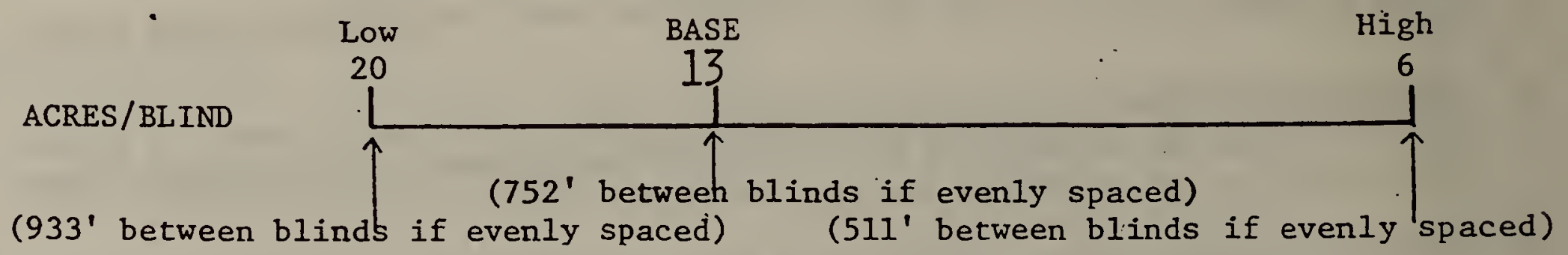

Primary Factors Influencing Selection of Optimum Capacity Level

- Supply and Availability of Waterfowl - The supply of waterfowl in the area being hunted affects a person's willingness to tolerate and accept higher densities, i.e., more hunting groups per acre; therefore areas that are abundant with waterfowl can accommodate more hunters per acre than in an area where game is scarce.

- Density of Vegetative Cover - The density of the vegetative cover affects the perceived closeness of other hunting groups; areas with dense vegetation should accommodate more groups per acre. 
HUNTING, BIG GAME

Suggested Optimum Capacity Range

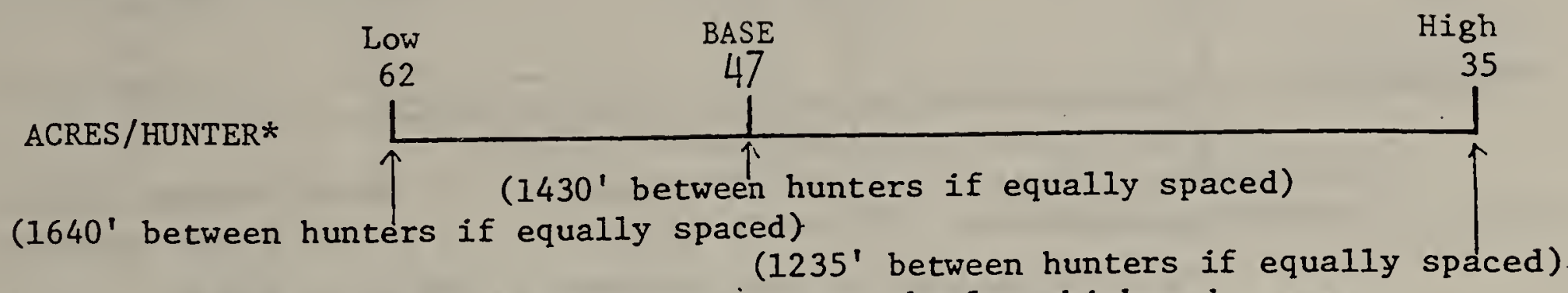

*NOTE: The above range is based solely upon the low, high and average SCORP Survey results.

Primary Factors Influencing Selection of Optimum Capacity Level

- Density of Vegetative Cover - The denser the vegetative cover, the Ionger it takes for a hunter to move through an area; hunting areas which have dense vegetation should accommodate fewer hunters per acre per day.

- Terrain - Areas with very rugges terrains accommodate less hunters per acre per day.

- Amount of Game in the Area - Hunters will move more slowly through an area and will be more willing to tolerate other groups of hunters if game is. readily available.

HUNTING, SMALL GAME

Suggested Optimum Capacity Range

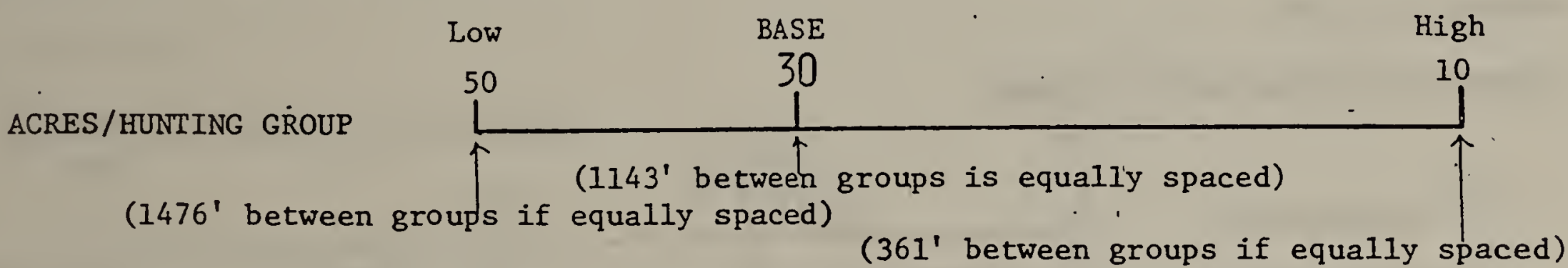

\section{Primary Factors Influencing Selection of Optimum Capacity Level}

- Density of Vegetative Cover - The denser the vegetative cover, the Ionger it takes a hunter to move through an area; hunting areas which have dense vegetation should accommodate fewer hunters per acre per day.

- Terrain - Areas with very rugged terrains accommodate less hunters per acre per day.

- Amount of Game in the Area - Hunters will move more slowly through an area and will be more willing to tolerate other grnups of hunters if game is readily available.

- Use of Hunting Dog - Hunters using dogs move slower through the hunting area than hunters without dogs; areas where hunting dogs are often used should accomodate less hunters per acre. 
HIKING

Suggested Optimum Capacity Range

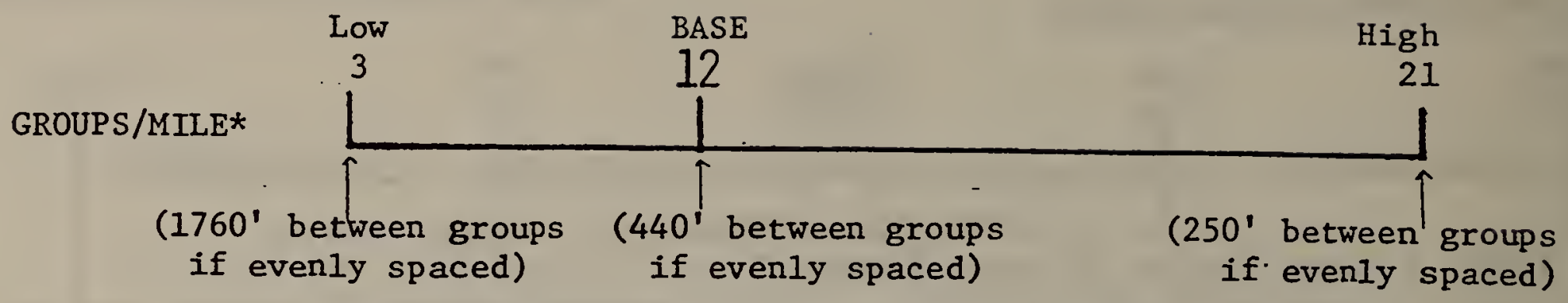

(*For the purpose of this activity a "group" is defined as a related hiking party consisting of one or more individuals)

\section{Primary Factors Influencing Selection of Optimum Capacity Leve1}

- Refer to Factors A and C

- Degree of Privacy - The type of vegetation and topographic characteristics found along the trail affect the perceived closeness of other hiking groups; a trail across densely wooded, rolling topography should accommodate more groups per mile of trail than a trail which extends across predominantly flat, open land.

- Stability of Trail Surface - The degree of stability of the trail surface affects the optimum carrying capacity of the trail; trail surfaces that are very stable, e.g., paved surfaces, can accommodate many hikers per mile of trail without damaging the trail surface.

\section{HORSEBACK RIDING}

Suggested Optimum Capacity Range

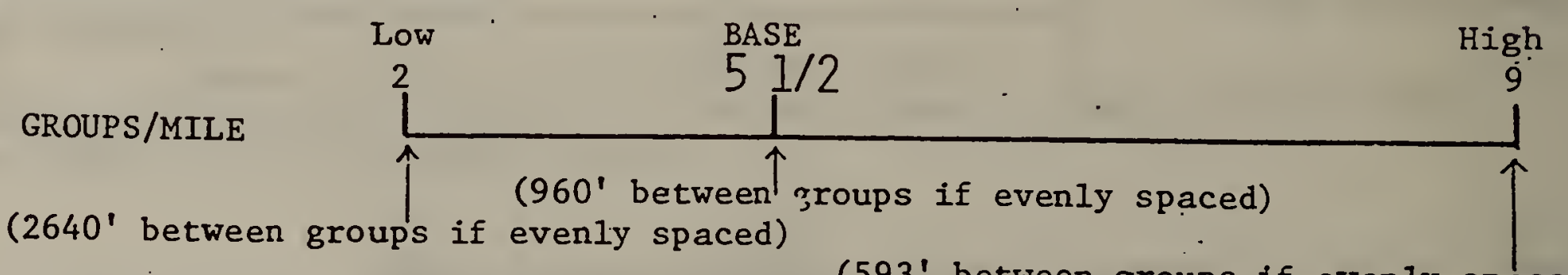

(593' between groups if evenly spaced)

Primary Factors Influencing Selection of Optimum Capacity Leve1

- Refer to Factors $\mathrm{A}$ and $\mathrm{C}$

- Degree of Privacy - The type of vegetation and topographic characteristics found along the trail affect the perceived closeness of other groups of riders; for example, a trail across densely wooded, rolling topography should accommodate more groups per mile of trail than a trail which extends across predominantly flat, open land.

- Stability of Trail Surface - The degree of stability of the trail surface affects the optimum carrying capacity of the trail; trail surfaces that are stable, e.g., those with dry, sandy soils versus those with wet, clay soils; can accommodate more riders per mile of trail with less damage to the trail surface. 
SKIING, NORDIC

Suggested Optimum Capacity Range

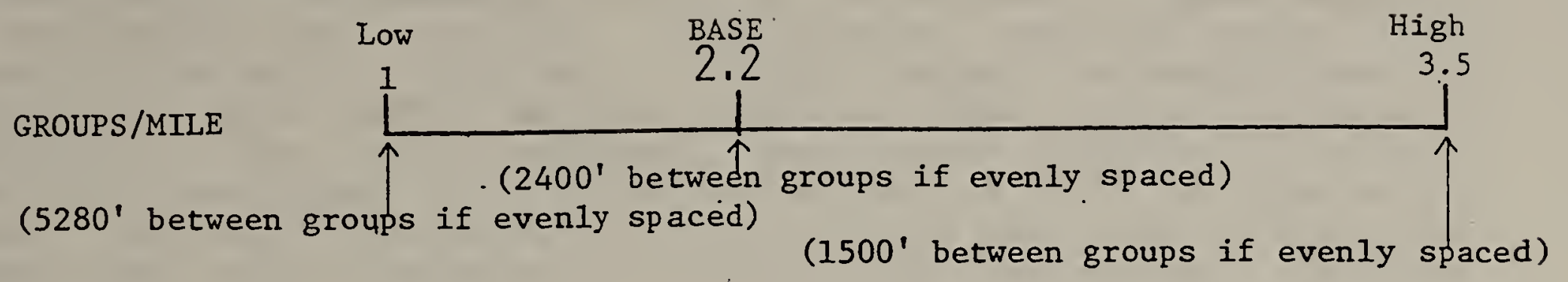

\section{Primary Factors Influencing Selection of Optimum Capacity Level}

- Refer to Factors $\mathrm{A}, \mathrm{C}$ and $\mathrm{H}$

- Degree of Privacy - The type of vegetation, forest and field and topographic characteristics of the ski area affects the perceived closeness of other ski groups. Ski areas which are predominantly wooded and moderately sloping can therefore support more skiers per mile of trail than a predomonantly open ski area.

- Stability of Snow Cover - The type and depth of snow cover along the trail affects carrying capacity; the carrying capacity should be lower on days when there is only a minimal amount of snow cover.

- Slope and Terrain Conditions - A ski trail which crosses a steep and rugged terrain will turnover less skiers per mile than a more gentle trail.

ICE SKÄTING

Suggested Optimum Capacity Range

SQUARE FEET OF ICE/PERSON (20' between skaters if equally spaced)

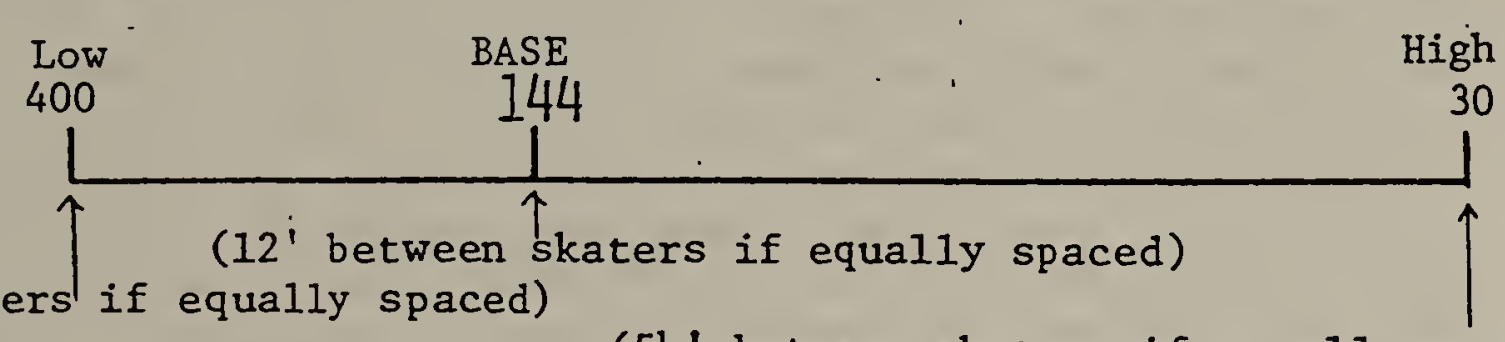
$\left(5 \frac{1}{2}\right.$ ' between skaters if equally spaced)

\section{Primary Factors Influencing Selection of Optimum Capacity Level}

- Refer to Factors $A, B$ and $E$

- Type of Skating Experience - Skaters on an ice rink will be willing to tolerate and accept more skaters per acre than skaters on natural ice.

- Circulation Control - Skating areas where there is controlled circulation of skaters can accommodate more skaters per acre of ice than where skater circulation is uncontrolled. 


\section{2}




\section{APPENDIX D}

Gap analyses are being conducted state by state under the general coordination of the USDI Fish \& Wildlife service. In Massachusetts, the Forestry \& Wildlife Department at UMass Amherst is conducting the research. The initial detailed cover type inventory is nearly complete. LANDSAT imagery is being used in combination with aerial video transects taken from a 2000-foot elevation. The video transects, and field checking to verify specific cover types, will allow definition of 30 to 40 vegetation types. The data representing the cover type maps will be on a GIS system that can be transferred to EOEA's ARC-INFO system. The data will be available to EOEA via the Internet.

In the mean time, existing GIS data layers have been used to conduct modified gap analyses:

- With the intention of highlighting areas of functional wildlife habitat, the Mass. Division of Fisheries \& Wildlife used GIS coverages showing river and stream corridors, nonforested wetlands, and Natural Heritage Program priority and estimated habitat.

- UMass Amherst Assistant Prof. David Kittredge started with a land use coverage of residential / commercial / industrial areas, representing sites that were "bad" ecologically. He used a buffering analysis to extend the influence of the developed areas, and then compared remaining areas that approximately represent undeveloped inner forest habitat, with an existing protected open space coverage. The intention is to highlight. inner forest habitat that is not currently protected.

- With permission to use Dave Kittredge's idea on EOEA's ARCINFO system, additional available coverages and newly digitized coverages allow for a slightly more elaborate analysis that was conducted for portions of the north-Quabbin region. A roads coverage was also buffered in a similar way to the residential / commercial / industrial. land use areas in order to remove the road corridors and associated area of influence from consideration as habitat. Also, DFW biologists were consulted relative to identifying general areas or landscape swathes that could be considered good habitat for inner forest species that are sensitive to human development such as the Fisher, Bobcat and River Otter. These area were identified on USGS quadrangle maps and digitized to enhance the information being considered in this modified gap analysis. In order to show how private landowners can add to the region's stewardship potential, parcels enrolled in the Forest Stewardship Program were also digitized, to be considered along with the protected open space. The DFW Hatural Heritage Program's data indicating priority habitat areas are also considered in this analysis. The intention of the modified gap analysis is to highlight important ecological areas and inner forest habitat that are unprotected, and also to highlight viable corridors that could potentially connect existing protected open space. 


\author{
APPENDIX E \\ Park Visitor Survey Results - Summer 1994
}

Survey Methodology:

Survey forms were distributed to campers at check-in during July 1994. Campers responded by selecting from several choices for each question. Day use visitors were surveyed by interview during July, 1994, selecting from several choices for each question. A survey distributed as an inclusion in the Wendell Post in June, 1994 sampled subscribers of that newspaper who live in or near Wendell. Return rates for surveys varied from park to park, ranging from 10\% to $20 \%$. The number of returned surveys $(48$ from campers, 64 from day users and 32 from the Wendell Post survey) do not allow for a quantitative statistical analysis. The following summaries show approximate totals.

\begin{tabular}{|c|c|c|c|c|}
\hline Visitors came from: & $\begin{array}{l}\text { local } \\
\text { towns } \\
\end{array}$ & $\begin{array}{l}\text { regional towns } \\
\text { \& Rt } 2 \text { corridor }\end{array}$ & $\begin{array}{l}\text { greater } \\
\text { Boston }\end{array}$ & out-of state \\
\hline Lake Dennison (camp) & $25 \%$ & $25 \%$ & $40 \%$ & $10 \%$ \\
\hline Otter River (camp) & $25 \%$ & & $65 \%$ & $10 \%$ \\
\hline Erving (camp) & $50 \%$ & $25 \%$ & $15 \%$ & $10 \%$ \\
\hline Dunn Pond (day use) & $55 \%$ & $22 \%$ & $15 \%$ & $8 \%$ \\
\hline Lake Dennison (day) & $75 \%$ & $25 \%$ & & \\
\hline Wendell (day) & $50 \%$ & $50 \%$ & & \\
\hline Wendell Post survey & $100 \%$ & & & \\
\hline
\end{tabular}

How many years the visitors have been returning:

\begin{tabular}{ccc} 
1st visit $1-5$ years & over 5 yrs \\
\cline { 2 - 3 } $40 \%$ & $40 \%$ & $20 \%$ \\
$80 \%$ & $10 \%$ & $10 \%$ \\
$30 \%$ & $30 \%$ & $40 \%$ \\
$30 \%$ & $55 \%$ & $15 \%$ \\
$30 \%$ & $40 \%$ & $60 \%$ \\
& $10 \%$ & $60 \%$
\end{tabular}

Lake Dennison (camp)

Otter River (camp)

Erving (camp)

Dunn Pond (day use)

Lake Dennison (day use)

Wendell (day use)

They learned of the park from:

Lake Denn. (camp)

Otter River (camp)

Erving (camp)

Dunn Pond (day)

Lake Denn. (day)

Wendell (day)

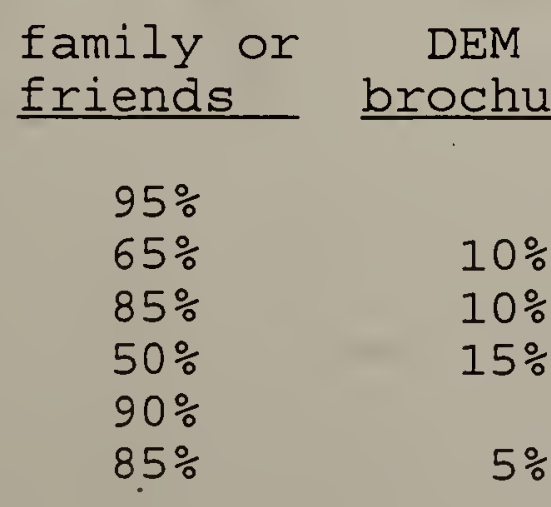

maps \& road

guidebooks signs media

$10 \%$

$10 \%$

$15 \%$

$5 \%$

$\begin{array}{rrr}25 \% & 5 \% & \\ 5 \% & & \\ & & 25 \% \\ & 10 \% & \\ 5 \% & 5 \%\end{array}$




\section{APPENDIX F}

\section{$\underline{\text { River Oriented Recreation }}$}

\section{Existing Access - (A)}

1 - west of Route 63 Bridge (privately owned)

2 - on Route 2, east of Erving landfill

3 - east side of railroad bridge on north side of river (privately owned)

4 - Hart's landing off East River Street

5 - Route 202 bridge and Millers River

6 - Routes $2 A$ and 202 and Millers River - ending point for the annual Millers River Rat Race

7 - confluence of Tully and Millers Rivers

8 - Attiol Conservation Commission land

9 - Athol Rod and Gun Club

10 - Tully Lake Dam (access for fishing along East Branch Tully River until confluence with West Branch Tully River)

11 - east side of Tully Lake

12 - downstream from Tarbell Brook

13 - north shore of Millers River, off Route 12

14 - north of Sunset Lake, south shore of Bear Meadow Brook

15 - western shore of Upper Naukeag Lake

16 - near Hubbardston-Templeton town line

\section{Potential Access - (a)}

1 - Farley Flats

2 - on Route 2 for approximately one mile on the north side of river

3 - end of Sears Road in Wendell

4 - mouth of Moss Brook on Route $2 A$

5 - east of Holtshire Road Bridge (privately owned)

6 - near Whitney Pond

7 - ustream from Whitney Pond

8 - eastern shore of Millers, downstream from Sunset Lake

9 - eastern shore of Bear Meadow Brook, upstream of Sunset Lake 


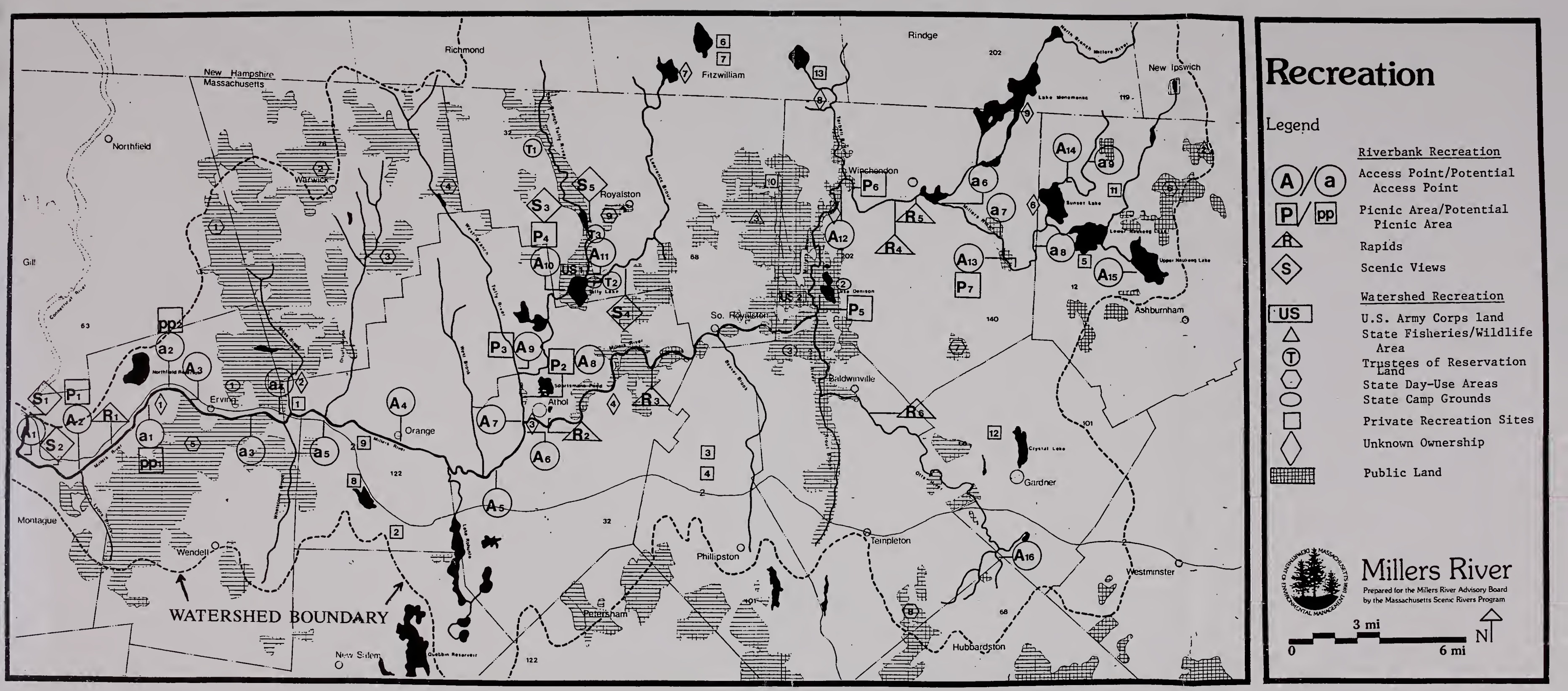





\section{APPENDIX G:Heritage Discovery Network Sites}

Name

1797 House

4 H Forest

Abercombie Play Area

Amherst College Lot

Amherst Woods and Hop Brook

Archibald Macleish Collection

ArtSpace Gallery

Artifacts Loft

Arts Council of Franklin County

Asgard House

Ashfield Historical Society

Atkins Flats

Atkins Reservoir

Augusta Savage Gallery

Balky Farms

Barton Cove Campground

Baseball Field

Bayberry

Beacon Field

Bear Swamp

Bear Swamp Visitor Center

Bears Den Reserve

Bement School

Bemardston Conservation Land

Bemardston Elementary School

Bemardston Fire and Water Supply

Bemardston Historical Society

Bemardston Historical Society Museum

Bioshelters, Inc.

Bisbee Family Mapie

Bitzer Fish Hatch

Blue Heron Farm

Bree-Z-Knoll Farm

Brewer Tatro Memorial Woods

Bridge of Flowers

Brookledge Sugarhouse

Buckland Recreation

Buckland State Forest

Bullard Farm Bed \& Breakfast and Conference

Bumett's Sugarhouse

Bumt Hill Farm

Butterfield Park

Cabot Woods Lot

Camp Avery

Camp Stonehenge

Camegie Public Library

Catamont State Forest

Catamount State Forest

Cemetery

Centennial House

Chapelbrook Reservation

Charity Farm

Charlemont Fairgrounds

Charlemont Historical Society

Cider Mill Pond

Colrain Elementary School

Colrain Fire District

Colrain Historical Society

Community Recreation Field

Conway Historical Society, Inc.

Conway State Forest

Conway Swimming Pool

Conway Town Forest

Corner Porches Bed \& Breakfast

Covered Bridge

Cowell Gymnasium

Craig Mountain Lookout

Cranston's Tree Farm

Cushman Brook Conservation Area

Cushman Park
Address

2 Charlemont Road

Shutesbury Rd., SCORP SITE \# 154006

Montague City Rd., SCORP SITE ID\# 11401

Reservoir Rd., SCORP SITE ID\# 289005

Central Amherst

One College Drive, Greenfield Comm. Coll.

7 Franklin Street

Carnegie Public Liurary, Avenue A

, 7 Franklin Street

550 Station Road

Main Street

South Amherst

- January Hills Road, SCORP SITE ID\# 272013

101 Africa House, Central Resi, University of

15 Main St.

Rte 2

Little Mohawk, SCORP ID\# 268005

East Amherst

Beacon Street, SCORP SITE ID \# 114025

Hawley Rd., SCORP SITE ID\# 013003

, New England Power Company

Neilson Rd., SCORP SITE ID \# 204002

Old Deerfield, SCORP SITE ID \# 074005

Bemardston Road, SCORP SITE ID \# 114049

Off of South St., SCORP SITE ID \# 029003

Off Rt 5 \& 10, SCORP SITE ID \# 029001

Church Street, Powers Institute

500 Sunderland Road

24 Old Chesterfield Rd.

Montague Rd., SCORP SITE ID \# 192001

Warner Hill Rd.

160 North County Rd.

Montague Rd., SCORP SITE ID \# 192001

189 Haydenville Rd

Rte 112, SCORP SITE ID \# 047012

Bray Rd., SCORP SITE ID \# 047011

89 Elm Street

Rt. 116, 42 N. Poland Rd.

East River St., SCORP SITE ID \# 223002

South End, SCORP SITE ID \# 192004

Scout Rd., SCORP SITE ID \# 114032

Barton Road, SCORP SITE ID \# 114031

, Avenue A

Route 112

Rt 2 and Rt 112, SCORP SITE ID \# 066003

Orange Rd., SCORP SITE ID \# 312013

94 Main Street

Williams burg Rd., SCORP SITE ID \# 013008

Bald Mountain Road, SCORP SITE ID \# 029010

Rt 8 A Heath Rd., SCORP SITE ID \# 053007

, Main Street

North-, East Amherst

Jacksonville Rd., SCORP SITE ID \# 066002

Off of Rt. 112, SCORP SITE ID \# 066006

Main Street

Leverett Rd., SCORP SITE ID \# 272006

, Main Street

W. Whately Rd., SCORP SITE ID \# 068001

Rte. 116, SCORP SITE ID \# OE 3010

Crickett Hill, SCORP SITE ID \# 068003

82 Baptist Corner Road

RRE 116, SCORP SITE ID \# 068011

Maple St., SCORP SITE ID \# 268007

197 Bellus Rd.

North-west Amherst

OFF Church Street., SCORP SITE ID \# 029007
City

Buckland

Leverett

Greenfield

Sunderland

Amherst

Greenfield

Greenfield

Montague

Amherst

Ashfield

Amherst

Shutesbury

Amherst

Northfield

Gill

Shelburne

Amherst

Greenfield

Ashfield

Florida

New Salem

Deerfield

Greenfield

Bernardston

Bernardston

Bernardston

Amherst

Chesterfield

Montague

Charlemont

Leyden

Montague

Shelburne Falls

Whately

Buckland

Buckland

North New

Conway

Heath

Orange

Montague

Greenfield

Greenfield

Montague

Colrain

Colrain

Warwick

Northfield

Ashfield

Bernardston

Charlemon

Amherst

Colrain

Colrain

Colrain

Shutesbury

Conway

Conway

Conway

Conway

Ashfield

Conway

Shelburne

Northfield

Ashfield

Amherst

Bernardston
Village

Phone

Buckland

Leverett

Greenfield

Sunderland

Amherst

Greenfield

Greenfield

Tumers Falls

Greenfield

Amherst

Ashfield

Amherst

Shutesbury

Amherst

Northfield

Gill

Shelburne

Amherst

Greenfield

Ashfielú

Florida

New Salem

Deerfield

Greenfield

Bernardston

Bernardston

Bernardston

Amherst

Chesterfield

Montague

Charlemont

Leyden

Montague

Shelburne Falls

Whately

Buckland

Buckland

North New

Conway

Heath

Orange

Montague

Greenfield

Greenfield

Turners Falls

Colrain

Colrain

Warwick

Northfield

Ashfield

Bernardston

Charlemont

Charlemont

Amherst

Colrain

Colrain

Colrain

Shutesbury

Conway

Coway

Conway

Conway

Ashfield

Conway

Shelburne

Northfield

Ashfield

Amherst

(413) 648-9600

(413) 549-3558

(413) 296-4717

(413) $339-4045$

(413) $774-3757$

(413) 665-3837

(508) 544-6959

(413) 369-4437

(413) $337-4454$

Bernardston

(413) $863-3214$

(413) 339-5504 
Name

D.A.R. State Forest

D.L Moody Museum

Davis Street School

Davis Street Tennis Courts

Dean's Sugarhouse

Deerfield Academy

Deerfield Fire District

Deerfield Inn

Deerfield Town Forest

Deerfield's Yellow Gabled House

Dexter Park School

Dry Hill Area

Dubuque State Forest

Dwyer Lot

E \& J Scott Orchards

E. Whately Grammar School

Eaglebrook School

Eastman Brook

Ed's Sugar Shack

Elementary School

Elementary School Lot

Elf Meadow

Emily's Amherst Bed \& Breakfast

Erving Elementary School

Erving Historical Engine House

Erving State Forest

Ervingside Playground

Eunice Williams Memorial

Falls River Inn \& Restaurant

Federal Street Grade School

Fort Pelham

Fort Shirley

Four Corners Elementary School

French King Bridge

Frontier Regional School

G. William Pitt House and Museum

GTD Conservation Land

Gale Brooks School

Gill Boat Ramp

Graves' Sugarhouse

Gray's Sugarhouse

Green Market Farm

Green River Conservation

Green River Elementary School

Green River Park

Green River/ Riverside

Greenfield Community College

Greenfield Department of Recreation

Greenfield High School

Greenfield Historical Society

Greenfield School

Greenfield Skating Rink

Greenfield Swimming Area

Greenfield(Leyden) Covered Bridge

Greenwood Farm

Griswold Wildife Sanctuary

Gulliver Meadow

HO Cook State Forest

H.O. Cook State Forest

Hail to the Sunrise Statue

Hamilton Orchards

Hampden Council Boy Scout Camp

Hampden Galiery

Hannah Dudley House

Harkness Brook

Harold White, Jr.

Hart Farm

Haskins Meadow

Hawlemont Regional Elementary School

Hawley Bog
Address

City

Rte 112

, Moody St. \& Highland Ave.

Davis Street, SCORP SITE ID \# 114038

Davis Street, SCORP SITE ID \# 114042

32 Hawk Hill Rd.

Old Deerfield, SCORP SITE ID \# 074006

THe Bars, SCORP SITE ID \# 074009

81 Old Main Street

Pine Nook Rd., SCORP SITE ID \# 074007

307 North Main St.

Dexter St., SCORP SITE ID \# 223004

Dry Hill, SCORP SITE ID \# 192016

Route 8A

Conway St., SCORP SITE ID \# 074016

RT. 116

River Road, SCORP SITE ID \# 337002

Pine Nook Rd, SCORP SITE ID \# 074008

North Amherst

72 S. County Rd.

West Pelham Road, SCORP SITE ID \# 272011

School Street, SCORP SITE ID \# 289006

South-East Amherst

Route 63, SCORP SITE ID \# 091003

Main Street

Rte 116, SCORP SITE ID \# 217015

Moore St., SCORP SITE ID \# 091004

Eunice Williams Drive, SCORP SITE ID \#

P.O. Box 762-Routes 5\& 10

Federal Street, SCORP SITE ID \# 114035

Pond Road, SCORP SITE ID \# 253001

East Oxbow, SCORP SITE ID \# 130001

Ferrante Ave., SCORP SITE ID \# 114033

, Rte 2

North Main Street, SCORP SITE ID \# 074003

, Main Street

Lampblack RD., SCORP SITE ID \# 114015

North Orange, SCORP SITE ID \# 223006

Rte 2, SCORP SITE ID \# 106002

104 Wilson Graves Rd.

Barnes Road

710 Rt. 202

N. of Swimming Area, SCORP SITE ID \# 114048

Meridian Street, SCORP SITE ID \# 114007

Off Deerfield, SCORP SITE ID \# 114018

Riverside Dr., SCORP SITE ID \# 114040

, One College Drive

Silver Street, SCORP SITE ID \# 114052

Union Streets, Corner of Church and

Federal Street, SCORP SITE ID \# 114051

Barr Avenue, SCORP SITE ID \# 114055

Nashs Mill Rd, SCORP SITE ID \# 114019

, Eunice Williams Drive

265 Millers Falls Rd.

Lampblack Rd., SCORP SITE ID \# 114006

Central Amherst

Off Rt. 8A, SCORP SITE ID \# 066005

State Farm Road

, Off Rte. 2

22 West Salem St.

Tunnel Road, Scorp Site ID \# 253006

Hampden Student Center, Southw, University of

114 Dudleyville Road

East Central Amherst

10 West Hawley Rd.

Central Amherst

North-east Amherst/Shutesbury

School Street, SCORP SITE ID \# 053006

97 Spring St., SCORP SITE ID \# 129006

\begin{tabular}{|c|c|c|}
\hline City & Village & Phone \\
\hline Goshen & Goshen & (413) 268-7098 \\
\hline Northfield & Northfield & (413) $498-3000$ \\
\hline Greenfield & Greenfield & \\
\hline Greenfield & Greenfield & \\
\hline Charlemont & Charlemont & (413) 625-2681 \\
\hline Deerfield & Deerfield & \\
\hline Deerfield & Deerfield & \\
\hline Deerfield & Deerfield & (413) 774-5587 \\
\hline Deerfield & Deerfield & \\
\hline Deerfield & South Deerfield & (413) 665-4922 \\
\hline Orange & Orange & \\
\hline Montague & Montague & \\
\hline Hawley & Hawley & (413) 339-5504 \\
\hline Deerfield & Deerfield & \\
\hline Ashfield & Ashfield & (413) 628-3327 \\
\hline Whately & Whately & \\
\hline Deerfieid & Deerfield & \\
\hline Amherst & Amherst & \\
\hline Leyden & Leyden & (413) $773-7619$ \\
\hline Shutesbury & Shutesbury & \\
\hline Sunderland & Sunderland & \\
\hline Amherst & Amherst & \\
\hline Amherst & Amherst & (413) 549-0733 \\
\hline Erving & Erving & \\
\hline Erving & Erving & (508) 544-6339 \\
\hline Erving & Erving & (508) 544-3939 \\
\hline Erving & Erving & \\
\hline Greenfield & Greenfield & \\
\hline Bernardston & Bernardston & (413) 648-9904 \\
\hline Greenfield & Greenfield & \\
\hline Rowe & Rowe & \\
\hline Heath & Heath & \\
\hline Greenfield & Greenfield & \\
\hline Millers Falls & Millers Falis & \\
\hline Deerfield & Deerfield & \\
\hline Colrain & Colrain & (413) 624-3701 \\
\hline Greenfieid & Greenfield & \\
\hline Orange & Orange & . \\
\hline Gill & Gill & \\
\hline Shelburne & Shelburne & (413) 625-6174 \\
\hline Ashfield & Ashfield & (413) 625-6559 \\
\hline New Salem & New Salem & (508) 544-7911 \\
\hline Greenfield & Greenfield & \\
\hline Greenfieid & Greenfield & \\
\hline Greenfield & Greenfield & \\
\hline Greenfield & Greenfield & \\
\hline Greenfield & Greenfield & (413) 774-3131 \\
\hline Greenfield & & (413) $772-1553$ \\
\hline Greenfield & Greenfield & \\
\hline Greenfield & Greenfield & (413) 863-9245 \\
\hline Greenfield & Greenfield & \\
\hline Greenfieid & Greenfield & \\
\hline Greenfield & Greenfield & \\
\hline Greenfield & Greenfield & \\
\hline Northfield & Northfield & (413) 498-5995 \\
\hline Greenfield & Greenfield & \\
\hline Amherst & Amherst & \\
\hline Coirain & Colrain & \\
\hline Colrain & Colrain & (413) 339-5504 \\
\hline Charlemont & Charlemont & \\
\hline New Salem & New Salem & (508) 544-6867 \\
\hline Rowe & Rowe & \\
\hline Amherst & Amherst & (413) 545-4197 \\
\hline Leverett & Leverett & (413) $367-2323$ \\
\hline Amherst & Amherst & \\
\hline Charlemont & Charlemont & (413) $339-4426$ \\
\hline Amherst & Amherst & \\
\hline Amherst & Amherst & \\
\hline Charlemont & Charlemont & \\
\hline Hawley & Hawley & \\
\hline
\end{tabular}


Name

Hawley Swamp (1.5 acres)

Heath Historical Society

Herter Art Gallery

Highland Park

Hillcrest Elementary School

Hillside Park

Historic Deerfield

Historical Hall

Hitchcock House

Holtshire Recreation Area

Holyoke Range

Howard Trust

Indian Cave

Industrial Land

Kent McCarthy Memorial Museum

King Philip's Hill

Kiwanis Park

Lake Mattawa

Lake Wyola

Larch Hill and Larch Hill North

Lawrence Swamp

Leslie Farm

Leverett Crafts \& Arts

Leverett Historical Society

Leverett Pond

Leverett State Forest

Leverett Sugar Shack

Leyden Elementary School

Leyden House Bed \& Breakfast

Leyden State Forest

Leyden Town Common

Leyden Woods/Green River Conservation Area

Library

Lincoln Avenue Bed \& Breakfast

Lion Knoll Gamp

Lion's Club

Longley Swamp

Lord Jeffery Inn

Lower Fort

Lower Mill River

Lunt Field

M M Belding Memorial

MCI Warwick

Mary Arms Property

Mary Lyon Birthplace

Massachusetts Forests and Parks

Maynard Pond

Memorial Hall Museum

Memorial Street Lot

Millers Falls Playground

Mohawk Trail Regional School

Mohawk Trail State Forest

Monroe Elementary School

Monroe State Forest

Monroe Town Forest 1

Monroe Town Forest 2

Montague Center Playground

Montague Industrial Park

Montague State Forest

Montague, Town of

Moore's Pond

Mount Sugarloaf State Reservation

Mount Toby State Forest

Mt. Castor Marsh

Mt. Grace State Forest

Mt. Pollux

Municipal Golf

Muns Ferry Boat Camp

Muzzy Field

New England Power Co. 1
Address

North-east Amherst

125A Herter Hall, University of Massachusetts

Highland Ave., SCORP SITE ID \# 114003

Crocker Ave., SCORP SITE ID \# 192005

Off Conway Street, SCORP SITE ID \# 114021

Hea'h Center, SCORP SITE ID \# 130005

15 Congress Street

Holtshire Rd., SCORP SITE ID \# 223005

South Amherst

Fire Lane, SCORP SITE ID \# 312016

Rt. 91 , SCORP SITE ID \# 114045

, Zoar Road

SCORP SITE ID \# 217021

Route 5 and 91 junction, SCORP SITE ID \#

Holtshire Rd., SCORP SITE ID \# 223008

North Shutesbury, SCORP SITE ID \# 272010

525 South Pleasant, West-central Amherst

South-East Amherst

South Amherst

Montague Rd., SCORP SITE ID \# 154001

North Leverett Road, Moores Corner

Putney Rd., SCORP SITE ID \# 154013

, SCORP SITE ID \# 154004

113 Long Plain Rd.

Brattleboro Rd., SCORP SITE ID \# 156001

200 Brattleboro Road

Old Country Rd., SCORP SITE ID \# 156002

Town Center, Greenfield Rd., SCORP SITE ID \#

Leyden Woods, SCORP SITE ID \# 114004

Hotpl Rd., SCORP SITE ID \# 312010

242 Lincoln Ave.

Off Oak Hill Rd., SCORP SITE ID \# 114023

Montague Rd., SCORP SITE ID \# 192025

South-Central Amherst

30 Boltwood Avenue

West-Central Amherst

North Central Amherst

Davis Street, SCORP SITE ID \# 114022

Ashfield Lake, SCORP SITE ID \# 013011

233 Richmond Rd. RFD 2, SCORP SITE ID \#

Stage Rd., SCORP SITE ID \# 074018

E. Buckland Rd., SCORP SITE ID \# 047001

Connecticut River Valley, Regional Office

Overland Road, SCORP SITE ID \# 114020

Memorial Street

Memorial Street, SCORP SITE ID \# 074004

Lyman Street, SCORP SITE ID \# 192017

Ashfield St., SCORP SITE ID \# 047003

Route 2 - Mohawk Trail

River Road, SCORP SITE ID \# 190004

Tilda Hill Road

Tilda Hill Rd., SCORP SITE ID \# 190002

Tulley Hill Rd., SCORP SITE ID \# 190001

Montague Center, SCORP SITE ID \# 192014

Millers Falls Road, SCORP SITE ID \# 192018

Montague Plains, SCORP SITE ID \# 1192022

\section{SCORP SITE ID \# 312018}

Rte 116

Long Plain Road, SCORP SITE ID \# 289009

East-Central Amherst

Winchester Rd

South-central Amherst

Bears Den Road, SCORP SITE ID \# 114045

Off Rte 10, SCORP SITE ID \# 217008

Hayen Street, SCORP SITE ID \# 223001

Cross Road, SCORP SITE ID \# 253008
City

Amherst

Heath

Amherst

Greenfield

Montague

Greenfield

Deerfield

Heath

Greenfield

Orange

Amherst

Warwick

Warwick

Greenfield

Rowe

Northfield

Bernardston

Orange

Shutesbury

Amherst

Amherst

Amherst

Leverett

Leverett

Leverett

Leverett

Leverett

Leyden

Leyden

Leyden

Leyden

Greenfield

Warwick

Amherst

Greenfield

Montague

Amherst

Amherst

Amherst

Amherst

Greenfield

Ashfield

Wanwick

Deerfield

Buckland

Greenfield

Deerfield

Deerfield

Montague

Buckland

Charlemont

Monroe

Monroe

Monroe

Monroe

Montague

Montague

Montague

Montague

Warwick

Deerfield

Sunderland

Amherst

Warwick

Amherst

Greenfield

Northfield

Orange

Rowe
Village

Cushman

Heath

Amherst

(ब7

Greenfield

Montague

Greenfield

Deerfield

Heath

Greenfield

Orange

Amherst

Warwick

Warwick

Greenfield

Rowe

Northfield

Bernardston

Orange

Shutesbury

Amherst

Amherst

Amherst

Leverett

Leverett

Leverett

Leverett

Leverett

Leyden

Leyden

Leyden

Leyden

Greenfield

Warwick

Amherst

Greenfield

Montague

South Amherst

Amherst

Amherst

Amherst

Greenfield

Ashfield

Warwick

Deertield

Buckland

Greenfield

Deerfield

Deerfield

Montague

Buckland

Charlemont

Monroe

Monroe

Monroe

Monroe

Montague

Montague

Montague

Turners Falls

Warwick

South Deerfield

Sunderland

Amherst

Warwick

South Amherst

Greenfield

Northfield

Orange

Rowe

(413) $337-4980$

(413) 545-0976

(413) $774-5581$

(413) $774-7452$

(508) 544-3491

(413) 339-4700

(413) $367-2800$

(413) 548-9486

(413) $772-0858$

(413) 549-0517 
Name

New England Power Co. 2

New England Power Co. 3

New Salem State Forest

New Salem Town Forest

Newton Street School Field

Nipponzan Myohoji

No. 2 Hydro Station

No. 3 Hydro Station

North Greenfield Park

North Parish School

Northampton Water Department

Northampton Water District

Northeast Utilities

Northeast Utilities/Western Mass Elec.

Northfield Boat Ramp

Northfield Country House

Northfield History Museum

Northfield Manor

Northfield Mountain Recreation \& Environmental

Northfield State Forest

Oak Courts Playground

Old Deerfield Grammar School

Old Town Farm Land

Orange Historical Society

Orange Municipal Airport

Orange State Forest

Orchard Terrace Bed \& Breakfast

Pauchaug Brook W.M.A

Peace Pagoda

Pelham Lake Park

Penfrydd Farm Bed \& Breakfast

Peskeumskut Park

Pine Hill Orchards

Pioneer Valley Institute

Pitt House Museum

Plum Brook North

Plum Brook South

Plum Brook West

Plum Springs

Podick and Katherine Cole Santuaries

Poets Seat Tower

Poland Brook W. M. A.

Pumping Station \& Covered Bridge

Quabbin Watershed

Recreation Field

River Maple Farm

Rocky Mountain Conservation Land

Rocky Mountain Park

Rowe Elementary School

Rowe Historical Society

Rowe State Forest

Ruth McIntyre Site

Salem Conservation Area

Salmon Falls \& Glacial Potholes

Sanderson Academy

Satan's Kingdom

Shattuck Park

Shearer's Sugarhouse

Shelburne Falls, Town of

Shelburne Grange Pool

Shelburne Historical Society

Shelburne Rd. Conservation Land

Shelburne State Forest

Shutesbury Community Center

Shutesbury State Forest

Shutesbury Town Forest

Silver Lake

Simmons Farm

Skillings Path

So. Deerfield Rod \& Gun
Address

City

Village

Phone

Tunnel Road, SCORP SITE ID \# 253007

Steel Brook Rd., SCORP SITE ID \# 253004

Blackington Rd., SCORP SITE ID \# 204001

West Street, SCORP SITE ID \# 204007

Newton Street, SCORP SITE ID.\# 114024

, 100 Cave Hill Raod

Conway Rd., SCORP SITE ID \# 047006

Creamery Ave., SCORP SITE ID \# 047007

Off Severance Street, SCORP SITE ID \# 114026

Place Terrace, SCORP SITE ID \# 114037

Haydenville Conway Rds, SCORP SITE ID \#

Whately Rd., SCORP SITE ID \# 091006

Rte. 63, SCORP SITE ID \# 0091006

215 Shelburne Road

Rte 63

181 School Street

Pine Street

1026 Millers Falls Rd. (Rt. 63

99 Millers Falls Road

Northfield Rd., SCORP SITE ID \# 217005

Oak Courts / Elm Street., SCORP SITE ID\#

Memorial Street, SCORP SITE ID \# 074017

Leyden Road, SCORP SITE ID \# 114041

, 41 North Main Street

East River Street, SCORP SITE ID \# 223009

Tully Rd., SCORP SITE ID \# 223011

124 N. Main Street

Rte. 63 North, SCORP SITE ID \# 217001

100 Cave Road

Pond Road, SCORP SITE ID \# 253003

105 Hillman Road

Avenue A, SCORP SITE ID \# 192023

248 Greenfield Road

One College Drive, Greenfield Comm. Coll.

Rt 112, SCORP SITE ID \# 066008

South-central Amherst

South-central Amherst

West Amherst

South- East Amherst

North-west Amherst/North-east

Off Rtes 2 \& 5, Rocky Mt.

Poland Rd., SCORP SITE ID \# 068004

Off Leyden Rd., SCORP SITE ID \# 114028

Rte 202, SCORP SITE ID \# 272007

RTe 116, SCORP SITE ID \# 068006

250 Brattleboro Rd

Mountain Rd., SCORP SITE ID \# 114047

Off Beacon St., SCORP SITE ID \# 114027

Pond Road, SCORP SITE ID \# 253012

Brown Rd., SCORP SITE ID \# 253005

Depot Rd., SCORP SITE ID \# 154014

Central Amherst

Buckland Rd., SCORP SITE ID \# 013010

Bernardston, SCORP SITE ID \# 029018

Off Federal Street, SCORP SITE ID \# 114002

270 Greenfield Rd.

Rte 2, SCORP SITE ID \# 268014

Comer of Maple \& Church Sts

Off Shelbume Rd., SCORP SITE ID \# 114005

Rte 2, SCORP SITE ID \# 268010

Cooleyville Rd., SCORP SITE ID \# 272009

Cooleyville Rd., SCORP SITE ID \# 272008

Dudleyville Rd., SCORP SITE ID \# 272005

Church Street, SCORP SITE ID \# 029016

South Amherst

Central Amherst

Mathews Road, SCORP SITE ID \# 074011
Rowe

Rowe

New Salem

New Salem

Greenfield

Leverett

Buckland

Buckland

Greenfield

Greenfield

Whately

Erving

Erving

Northfield

Northfield

Northfield

Northfield

Northfield

Northiield

Greenfield

Deerfield

Greenfield

Orange

Orange

Orange

So. Deerfield

Northfield

Leverett

Rowe

Colrain

Montague

Colrain

Greenfield

Colrain

Amherst

Amherst

Amherst

Amherst

Amherst

Greenfield

Conway

Greenfield

Shutesbury

Conway

Bernardston

Greenfield

Greenfield

Rowe

Rowe

Leverett

Amherst

Shelburne Falls

Ashfield

Bernardston

Greenfield

Colrain

Shelburne Falls

Shelburne

Shelburne Falls

Greenfield

Shelburne

Shutesbury

Shutesbury

Shutesbury

Bernardston

Amherst

Amherst

Deerfield
Rowe

Rowe

New Salem

New Salem

Greenfield

Leverett

Buckland

Buckland

Greenfield

Greenfield

Whately

Erving

Erving

Greenfield

Northfield

Norhtfield

Northfiled

Northfield

Northfield

Northfield

Greenfield

Deerfield

Greenfield

Orange

Orange

Orange

So. Deerfield

Northfield

Leverett

Rowe

Colrain

Montague

Colrain

Greenfield

Colrain

South Amherst

South Amherst

Amherst

Amherst

Amherst

Conway

Greenfield

Shutesbury

Conway

Bernardston

Greenfield

Greenfield

Rowe

Rowe

Leverett

Amherst

Shelburne Falls

Ashfield

Bemardston

Greenfield

Colrain

Shelburne Falls

Shelburne

Shelburne Falls

Greenfield

Shelburne

Shutesbury

Shutesbury

Shutesbury

Bemardston

Amherst

Amherst

Deerfield $(\varnothing Z$

(413) $367-2202$

(413) $774-2227$

(413) 659-3714

(413) 498-2692

(413) 498-2049

(413) 498-2650

(413) 659-3715

(627) $575-0408$

(413) $665-3829$

(413) $367-2202$ 
So. Deerfield Watershed

Rt. 5, south Deerfield, SCORP SITE ID \# 074014

Conway Street, SCORP SITE ID\# 074001

Roaring Brook Rd., SCORP SITE ID \# 068007

Glenn Road, SCORP SITE ID \# 337006

Watson-Spruce Corner Rd.

Depot Road

230 Wilson Graves Rd

Rte. 2 in Gill, SCORP SITE ID \# 106007

Off E. Leverett Rd., SCORP SITE ID \# 154011

Heath Center, SCORP SITE ID \# 13009

Student Union Building, University of

Rte 116, SCORP SITE ID \# 289008

Park Road, SCORP SITE ID \# 289004

21 River Road

South Amherst

Wendell Depot Rd., SCORP SITE ID \# 319005

72 Teawaddle Hill Rd.

Mountain Rd., SCORP SITE ID \# 114030

559 Main St.

29 Highland Ave.

Washington Street, SCORP SITE ID \# 114036

1 Sunset Court

Tower Rd., SCORP SITE ID \# 268002

River Rd., SCORP SITE ID \# 337005

Main Street, SCORP SITE ID \# 114039

Heath Center, SCORP SITE ID \# 130006

Off Bald Mt. Rd., SCORP SITE ID \# 029005

Zoar Road, SCORP SITE ID \# 253009

Off Boyle Rd., SCORP SITE ID \# 106004

South Main Street, SCORP SITE ID \# 289003

Lee Road, SCORP SITE ID \# 074013

Kings Highway, SCORP SITE ID \# 253010

Davis Mine Rd., SCORP SITE ID \# 253013

Locks Pond Rd., SCORP SITE ID \# 029019

Rt. 63, SCORP SITE ID \# 217023

South-West Amhert

Fine Arts Center, University of Massachusetts

Center Rd.

East-Central Amherst

North Central Amherst

south end of Town Common, Behind the fire

, Warwick Center

Athol Rd., SCORP SITE ID \# 312014

Montague Road

East-central Amherst

248 Greenfield Rd

Wheeler House, Central Residen, University of

Central Amherst

P.O. Box 246, Main St.

test
Deerfield

Conway

Whately

Ashfield

Conway

Colrain

Gill

Leverett

Heath

Amherst

Sunderland

Sunderland

Whately

Amherst

Wendell

Leverett

Greenfield

Amherst

Greenīield

Greenfield

Amherst

Shelburne

Whately

Greenfield

Heath

Bernardston

Rowe

Gill

Sunderland

Deerfield

Rowe

Rowe

Bernardston

Northfield

Amherst

Montague

Amherst

Gill

Amherst

Amherst

Warwick

Warwick

Warwick

Wendell

Amherst

Colrain

Amherst

Shelburne

Amherst

Deerfield

test
Deerfield

Deerfield

Conway

Whately

Ashfield

Conway

Colrain

Gill

Leverett

Heath

Amherst

Sunderland

Sunderland

Whately

Amherst

Wendell

Leverett

Greenfield

Amherst

Greenfield

Greenfield

Amherst

Shelburne

Whately

Greenfield

Heath

Bernardston

Rowe

Gill

Sunderland

Deerfield

Rowe

Rowe

Bernardston

Northfield

Amherst

Turners Falls

Amherst.

Gill

Amherst

Amherst

Warwick

Warwick

Warwick

Wendell

Amherst

Colrain

Amherst

Shelburne

Amherst

Deerfield

test $(\varnothing Z$

(413) 628-3268

(413) $339-5504$

(413) $625-9230$

(413) 545-0792

(413) 665-3113

(413) 548-9526

(413) $253-5000$

(413) 774-3329

(413) 549-7554

(413) 863-3221

(413) 545-3670

(413) 863-2297

(518) 544-3491

(508) 544-3461

(413) 659-3797

(413) 624-3481

(413) 545-0680

(413) 339-5504

(413) $773-5186$

(423) 444-4444 


\section{DEPARTMENT OF ENVIRONMENTAL MANAGEMENT GREENWAYS AND TRAILS DEMONSTRATION GRANTS PROGRAM}

\section{Project Summaries}

AMC/Metacomet \& Monadnock Trail Committee

$\$ 3000$

The Appalachian Mountain Club's Berkshire Chapter maintains the Metacomet \& Monadnock Trail. The Chapter will be taking a pro-active role in the protection of this 117 mile trail by compiling information on property owners in Franklin County. This grant will fund a graduate student to start this inventory, digitize maps, and set up an ownership database.

Bay State Trail Riders

$\$ 2513$

The Bay State Trail Riders will coordinate the restoration of the Around-the-Mountain loop trail at the Mt. Grace State Forest. Several volunteer groups, from scouts to snowmobilers, will be working together to rehabilitate the northern and southern loops of the trail to stop erosion, install water bars, brush-back the trail, and clear new paths. This grant will fund the initial professional management work necessary before the volunteers begin.

Mount Grace Land Conservation Trust, Inc.

$\$ 2900$

The Mount Grace Land Conservation Trust will complete a feasibility study for establishing greenways and trails along the east and west branches of the Tully River. Using GIS, Mount Grace will analyze natural resource, land use, and land ownership data to determine the best location for potential trails. This information will be used to identify and eventually secure gaps in existing trails, creating the potential for continuous hiking from downtown Athol to Tully Lake and Tully Mountain. Grant funds will be used to hire a GIS expert to generate the digital information needed for the analysis.

Orange Revitalization Partnership

The Orange Revitalization Partnership has been working with the Millers River Watershed Council and the Town of Athol to build consensus and develop conceptual designs for a 7-mile multi-purpose trail linking downtown Orange to downtown Athol along the Millers River. Now in the beginning stages of negotiating easements, the 40-member community Greenway Committee is seeking professional assistance to finalize the proposed route and develop a detailed trail and management plan. Grant funds will be applied toward hiring a trail consultant to assist with this work.

City of Gardner and Town of Winchendon

$\$ 4,500$

The City of Gardner and the Town of Winchendon are working together to create a 14mile recreation trail linking the two municipalities. Grant funds will be used to complete a comprehensive, preliminary master plan and map of the proposed trail. In addition, the grant will fund the installation of an information kiosk at the entrance to the first mile of the trail currently underway in Gardner. 


\section{APPENDIX I}

Laurel Lake Dam Description (from 1987 Dam Inspection / Evaluation Report - prepared for DEM by GEI Consultants, Inc.)

The dam is located on Laurel Lake Road in Erving State Forest, impounding approximately 510 acre-feet of water. The outlet from the dam is an unnamed brook which flows into Moss Brook, through Harris Swamp about $0.5 \mathrm{mile}$ downstream of the dam, and into the Millers River about two miles downstream of the dam. The dam is classified as having a low hazard potential because there are no inhabited structures downstream of the dam site which could be affected if the dam failed, although the culvert under Wendell Road and Wendell Road would be damaged in such an event.

Laurel Lake dam is approximately 125 , feet long, with a crest width varying from 25 to 50 feet. An open-channel spillway, which is spanned by a timber bridge, is located about halfway between the abutments. There is a concrete stoplog structure at the upstream end of the spillway. This is the only control for the lake level.

The dam was originally constructed as an earth embankment dam covered by smooth-faced paving stones. The downstream faces of the left and right embankments were vertical dry-stone masonry walls up to 5 feet high. The right embankment was later widened about 10 feet by placing fill on the upstream side (to widen the roadway on the dam crest). Sand and gravel has been placed along the downstream side of the right embankment to stabilize the partially collapsed dry-stone-masonry wall.

The depth of the lake just upstream from the stoplog structure is about 6 inches underlain by 3 feet of soft sediment. 


\section{Laurel Lake Dam Recommendations}

- The trees and brush growing on the upstream face of the right and left embankments are being removed. The stumps and roots should be excavated and the holes backfilled with compacted impervious fill.

- The stoplog timbers are deteriorating and should be replaced with modifications to allow removal during periods of heavy flow, or the entire structure modified with a gate that can be drawn up from the bottom of the spillway.

- A dogging device should be installed on the stoplog structure to prevent vandals from removing stoplogs from the dam, while permitting easy access for operation during an emergency. - The 4-inch-thick concrete lining walls poured against the spillway masonry training walls have deteriorated and should be removed. The stone masonry walls behind the concrete should then be inspected and remedial repairs made if required.

- Brush should be removed from the downstream toe of the left and right embankments, and the area inspected for seepage.

- The top stones of the dry stone masonry wall on the downstream face of the left embankment should be realigned.

- Trees and shrubs should be removed from the dam site and the dam inspected on a regular basis.

- A formal emergency action plan should be developed including monitoring the dam during heavy rainfall and spring runoff, and procedures for notifying local authorities in the event of an emergency. 
Dunn Pond Dam Description (Information from 1995 Dam Inspection/Evaluation Report - prepared for DEM by Root Engineering)

Situated between Pearl street and Betty spring Road in Gardner, the Dunn Pond Dam normally stores 60 acre-feet of water. The dam is an earthfill embankment with a concrete core wall, it's crest stretching a length of about 160 feet and a width of 8 feet. Dunn Pond continues to be used for recreation, as was the original intent of the dam's construction in 1934 .

The dam's spillway approach channel is 10.5 feet wide and 4 feet deep. It is located in the pond area upstream of the right dam abutment. The exit channel from the spillway is 32 feet long with low concrete training walls. Dunn Pond Dam's gated outlet is a 24 inch cast iron low-level conduit that was inserviceable at the time of the dam's most recent inspection due to a missing shear key for the hand wheel operator.

Structural deficiencies coupled with the outlet being inoperable lead to the conclusion that Dunn Pond Dam is in poor condition and in need of repair. The dam is classified as a significant hazard because of its potential threat to downstream structures in the event of dam failure. Betty Spring Road, a secondary road, is located 500 feet downstream of the dam. Also in close proximity is a commercial area that lies 1.4 miles downstream at the intersection of MA Route 2 and business route 140. A recent and substantial capital investment to rehabiltate the pond for recreation would also be affected by dam failure. 
- Provide construction procedures for the removal of trees, stumps and roots and make recommendations for the proper restoration of the soil disturbed by the removal process.

- Investigate the need for further repair to the outlet gate. (It is assumed that DEM, Forest and Parks will install the missing shear key.)

- Investigate the failed concrete in the left spillway tarining wall and make recommendations for repair or replacement. Investigate the spillway exit channel training walls and make recommendations for stream bank protection.

- Investigate the failed concrete in the gatewell and make recommendations for repair or replacement.

- Cut the brush on the upstream dam embankment.

- Regrade the dam crest and provide a gravel path for pedestrian use.

- Trees growing on the downstream slope of the embankment should be removed, the roots grubbed, the embankment graded, and the ground cover established. The area should be cleared to 20 feet below the toe of the dam.

- Repair or replace the left spillway training wall.

- Place streambank protection along the spillway exit channel.

- Repair or replace the gatewell. foundation.

- Repair or replace the outlet gate.

- Remove debris from low level outlet intake structure. Confirm the presence of and/or install a trashrack on the inlet.

- Remove debris from the outlet channel for the low level outlet.

- Evaluate the outlet channel lining and the seepage through the outlet headwall. Repair or replace these structures, as necessary.

- Prepare an operations and maintenance manual for the dam. The manual should include provisions for annual technical inspection of the dam and for surveillance of the dam during periods of heavy precipitation and high water levels. The procedures should delineate the routine operations and maintenance work to be done to ensure satisfactory performance and upkeep of the facility.

A Notice of Intent will need to be filed with the Gardner Conservation Commission prior to any work being done on the Dunn Pond Dam. 


\subsection{Cost Estimates}

\begin{tabular}{|c|c|}
\hline Remedial Measure & Total \\
\hline 1. Cut and remove upstream brush ${ }^{+}$ & $\$ 400$ \\
\hline 2. Grade dam crest \& gravel path & $\$ 2,000$ \\
\hline 3. Cut and remove downstream trees & $\$ 15,000$ \\
\hline 4. $\quad$ Repair/replace left spillway wall & $\$ 3,000$ \\
\hline $\begin{array}{l}\text { 5. Place bank protection along } \\
\text { spillway exit channel }\end{array}$ & $\$ 2,000$ \\
\hline 6. Repair/replace gatewell & $\$ 8,000$ \\
\hline 7. Repair/replace outlet gate & $\$ 7,500$ \\
\hline $\begin{array}{l}\text { 8. Investigate, clear, and repair } \\
\text { intake }^{+}\end{array}$ & $\$ 2,000$ \\
\hline $\begin{array}{l}\text { 9. Remove debris from low level } \\
\text { outlet channel }\end{array}$ & $\$ 200$ \\
\hline $\begin{array}{l}\text { 10. Line outlet channel and repair } \\
\text { outlet headwall }\end{array}$ & $\$ 4,000$ \\
\hline Subtotal & $\$ 44,000$ \\
\hline $20 \%$ Engineering \& Contingencies & $\$ 8,800$ \\
\hline $\begin{array}{l}\text { Total; 1-10 including Engineering and } \\
\text { Contingencies }\end{array}$ & $\$ 53,000$ \\
\hline 11. O \& M Manual & $\$ 3,000$ \\
\hline Total Estimated Project Cost & $\$ 56,000$ \\
\hline
\end{tabular}

- The estimated costs, including labor and materials, are based on limited investigations and is provided for general information only. Actual construction costs may vary.

+ Work can be undertaken without a Chapter 253 permit or assistance from an engineer. Permits other than Chapter 253 may be required. 
Sheomet Lake Dam Description (from 1987 Dam Inspection / Evaluation Report - prepared for DEM by GEI Consultants, Inc.)

The dam is located on Tully Brook in Warwick state Forest, about 500 feet north of Athol Road. When Sheomet Lake is at a normal level, the dam impounds about 174 acre-feet of water. The dam is classified as having a significant hazard potential due to one inhabited structure on Royalston Road, about $4.5 \mathrm{miles}$ downstream of the dam site, which could potentially be affected by a failure of the dam. Also, two bridges downstream of the dam could be damaged in the event of a dam failure. One bridge carries the park access road over Tully Brook about 160 feet downstream of the dam, and the other bridge carries Athol Road over Tully Brook about 750 feet downstream of the dam.

The main dam consists of a downstream dry stone masonry wall with an upstream earthfill embankment. The upstream face of the main dam is protected by heavy riprap. The main dam is approximately 150 feet long and has a maximum height of 17 feet. An earth embankment extends from the right end of the main dam to the Park Access Road at the right abutment. The earth embankment is 150 feet long and has a maximum height of 5 feet. The principal spillway has a crest length of 60 feet and is located at the left end of the masonry dam. On the left side of the spillway is a bedrock knoll and to the left of the knoll is a small dike embankment. The dike embankment is about 65 feet long and has a maximum height of about 8 feet. The downstream face of the dike embankment is a dry stone masonry wall and the upstream face consists of earth fill. The dike embankment spans between the bedrock knoll and the beach access road on the left abutment. There is a low-level-outlet structure located under the masonry dam. 
- Place compacted sand and gravel on the downstream side of the dike embankment sloping up to the dike crest to stabilize the embankment. Install a toe drain system downstream of the dike embankment to filter and collect seepage water coming through the dike.

- Investigate and repair areas where water flows into the lake bottom immediately upstream of the spillway weir.

- Investigate the areas of seepage found on the downstream side of the main dam and earth embankment related to location and amount of fine material coming from the embankment.

- Open low-level outlet pipe once a year to clear out any debris which may collect in and around the outlet.

- Continued removal and control of trees and shrubs on the dike, and backfilling with compacted impervious material.

- A registered civil engineer should conduct a technical inspection of the dam once a year.

- Institute a formal emergency action plan to include monitoring the dam during heavy rainfall and spring runoff, and procedures for notifying downstream authorities in the event of an emergency. 
Richards Reservoir Upper and Lower Dams Description (from 1987 Dam Inspection / Evaluation Report - prepared for DEM by GEI Consultants, Inc.)

The dams are located in Warwick state Forest along Black Brook at the south end of Richards Reservoir. The lower dam is approximately 135 feet south of the upper dam. The water that was impounded between the two dams was used as a small swimming area for Camp Warwick when the MCI facility was in operation. The upper dam impounds Richards Reservoir, which has a normal storage capacity of 58 acre-feet. Both dams have heights of less than 10 feet and are classified as small and low hazard dams. There are no inhabited structures within the potential flood zone downstream of the dam site. Engineering data is not available for these dams. The assessment is based on visual inspection, hydraulic computations and DEM reports of past performance.

\section{Recommendations}

\section{Upper Dam:}

- The downstream masonry wall has partially collapsed and should be restored or stabilized with a soil berm.

- The brush which has grown on the right and left downstream embankments should be removed. Growth of shrubs and trees should be monitored and controlled on an ongoing basis.

- The crest of the dam should be leveled adjacent to the concrete spiliway walls.

- Concrete walls should be repaired by adding surfacing material in worn sections.

- A technical inspection should be conducted annually, and a formal emergency action plan should be established.

\section{Lower Dam:}

- Hydraulic and hydrologic study indicates the dam will be overtopped during the "design flood". The upper two feet of the right concrete wall should be removed so that this area will operate as an emergency spillway.

- Concrete walls should be repaired by adding surfacing material in worn sections.

- A technical inspection should be conducted annually. The lower dam might be used in the future to impound water for swimming if camp Warwick is reopened. 

